Prepared in cooperation with the U.S. Army Corps of Engineers

\title{
Continuous Stream Discharge, Salinity, and Associated Data Collected in the Lower St. Johns River and Its Tributaries, Florida, 2017
}

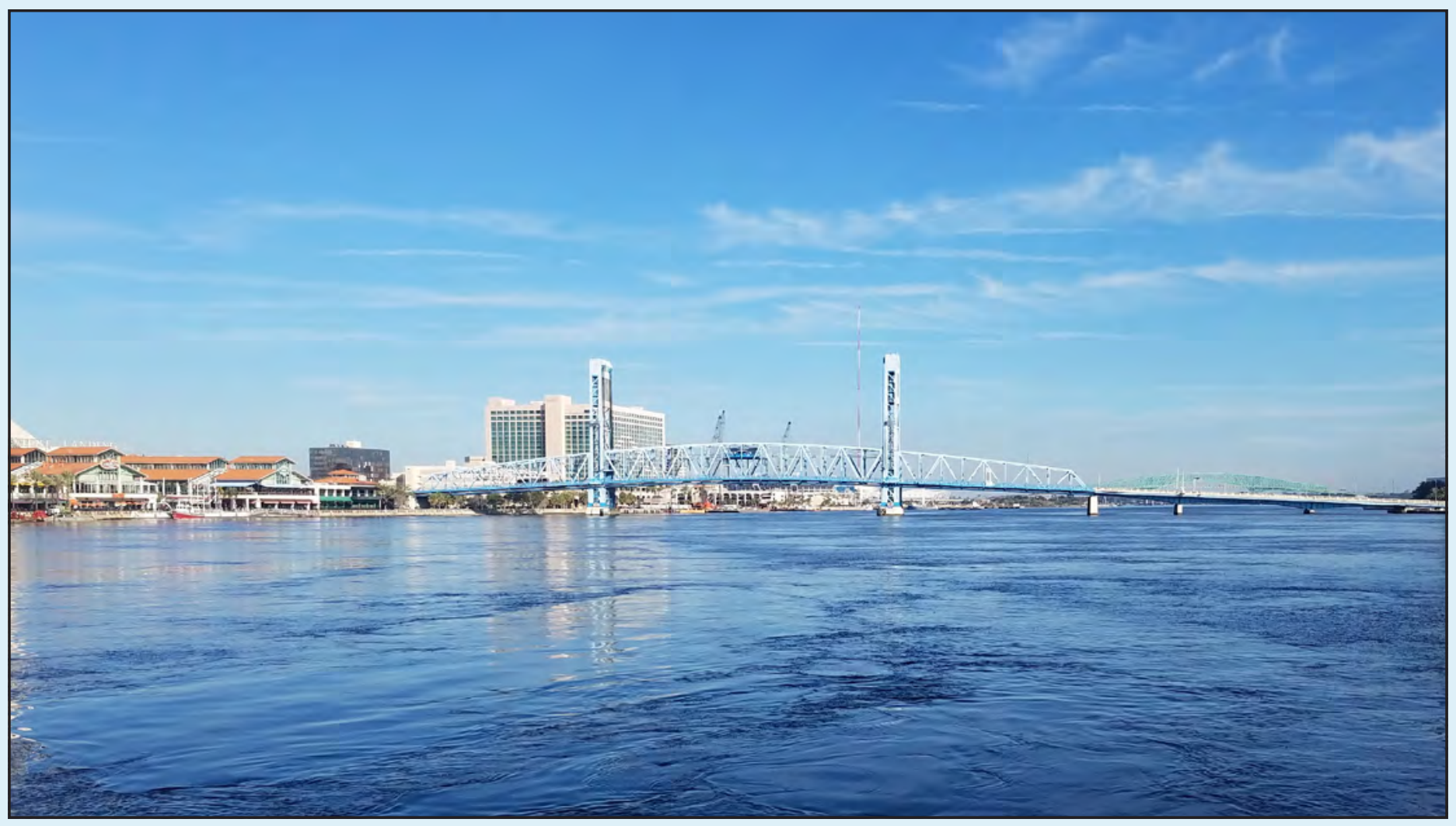

Open-File Report 2019-1078 
Cover. St. Johns River at Jacksonville monitoring site (02246500), looking east (downstream). Photograph by Pat Ryan, U.S. Geological Survey. 


\section{Continuous Stream Discharge, Salinity, and Associated Data Collected in the Lower St. Johns River and Its Tributaries, Florida, 2017}

By Patrick J. Ryan

Prepared in cooperation with the U.S. Army Corps of Engineers

Open-File Report 2019-1078 


\title{
U.S. Department of the Interior DAVID BERNHARDT, Secretary
}

\author{
U.S. Geological Survey \\ James F. Reilly II, Director
}

U.S. Geological Survey, Reston, Virginia: 2019

For more information on the USGS - the Federal source for science about the Earth, its natural and living resources, natural hazards, and the environment-visit https://www.usgs.gov or call 1-888-ASK-USGS.

For an overview of USGS information products, including maps, imagery, and publications, visit https://store.usgs.gov.

Any use of trade, firm, or product names is for descriptive purposes only and does not imply endorsement by the U.S. Government.

Although this information product, for the most part, is in the public domain, it also may contain copyrighted materials as noted in the text. Permission to reproduce copyrighted items must be secured from the copyright owner.

Suggested citation:

Ryan, P.J., 2019, Continuous stream discharge, salinity, and associated data collected in the lower St. Johns River and its tributaries, Florida, 2017: U.S. Geological Survey Open-File Report 2019-1078, 35 p., https://doi.org/10.3133/ ofr20191078.

ISSN 2331-1258 (online) 


\section{Acknowledgments}

The author thanks the data collection personnel from the U.S. Geological Survey Caribbean-

Florida Water Science Center in Orlando, Florida, for their help collecting and analyzing the streamflow and water-quality data. 



\section{Contents}

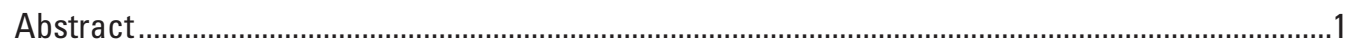

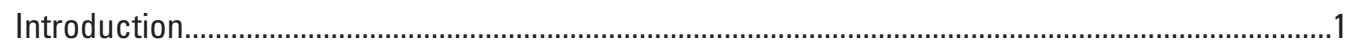

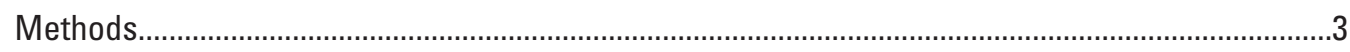

Methods of Data Collection and Processing ............................................................................

Description of St. Johns River Main-Stem Sites ....................................................................

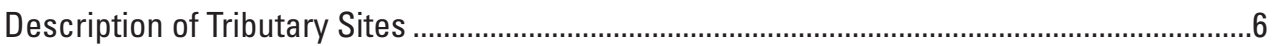

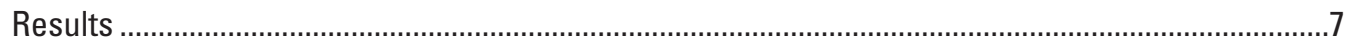

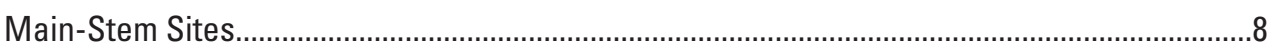

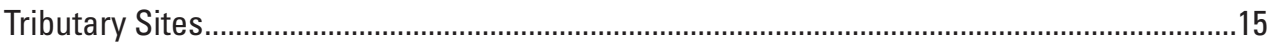

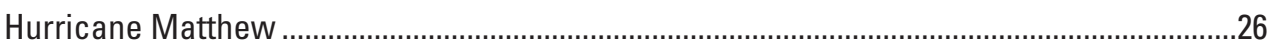

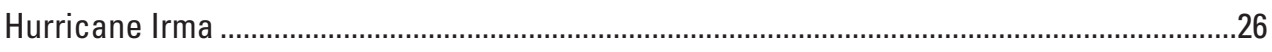

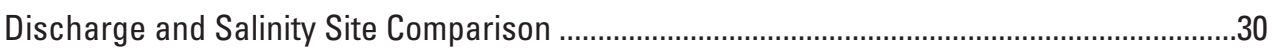

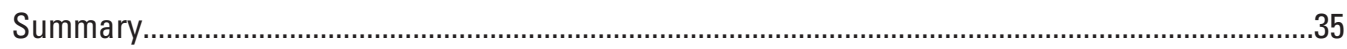

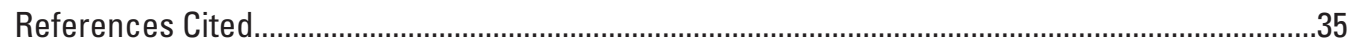

\section{Figures}

1. Map showing U.S. Geological Survey data collection sites on the St. Johns River

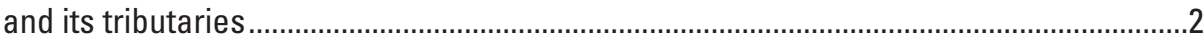

2. Map showing U.S. Geological Survey data collection sites in Duval County, Florida ......4

3. Graph showing 2017 water year monthly rainfall and mean monthly rainfall for

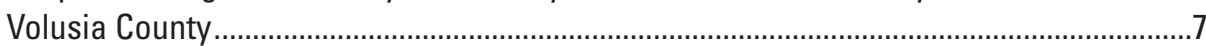

4. Graph showing 2017 water year monthly rainfall and mean monthly rainfall for Putnam County ...........................................................................................................

5. Graph showing 2017 water year monthly rainfall and mean monthly rainfall for

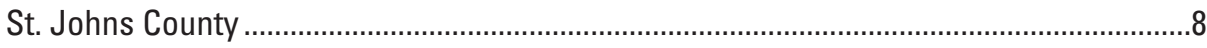

6. Graph showing 2017 water year monthly rainfall and mean monthly rainfall for

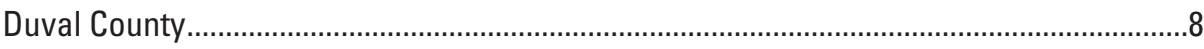

7. Hydrograph of daily mean tidally filtered discharge for St. Johns River at Astor,

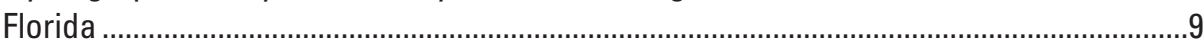

8. Quantile plot of annual mean tidally filtered streamflow data for St. Johns River at

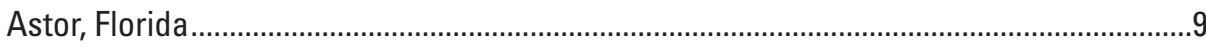

9. Hydrograph of daily mean tidally filtered discharge for St. Johns River at Buffalo

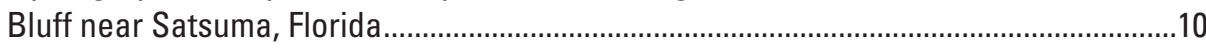

10. Quantile plot of annual mean tidally filtered streamflow data for St. Johns River at Buffalo Bluff near Satsuma, Florida.........................................................................10

11. Graph of daily maximum, minimum, and mean salinity for St. Johns River at Dancy Point near Spuds, Florida

12. Graph of daily maximum, minimum, and mean salinity for St. Johns River below Shands Bridge near Green Cove Springs, Florida.

13. Graph of daily maximum, minimum, and mean salinity for top location of St. Johns River Buckman Bridge at Jacksonville, Florida...

14. Graph of daily maximum, minimum, and mean salinity for bottom location of St. Johns River Buckman Bridge at Jacksonville, Florida. 
15. Graph of daily maximum, minimum, and mean salinity for St. Johns River at

Christopher Point near Jacksonville, Florida

16. Graph of daily maximum, minimum, and mean salinity for St. Johns River below Marco Lake at Jacksonville, Florida....

17. Hydrograph of daily mean tidally filtered discharge for St. Johns River at Jacksonville, Florida.

18. Graph of daily maximum, minimum, and mean salinity for St. Johns River at Jacksonville, Florida.

19. Quantile plot of annual mean tidally filtered streamflow data for St. Johns River at Jacksonville, Florida.

20. Graph of daily maximum, minimum, and mean salinity for top location of St. Johns River Dames Point Bridge at Jacksonville, Florida.

21. Graph of daily maximum, minimum, and mean salinity for bottom location of St. Johns River Dames Point Bridge at Jacksonville, Florida

22. Hydrograph of daily mean tidally filtered discharge for Julington Creek at Old St. Augustine Road near Bayard, Florida.

23. Graph of daily maximum, minimum, and mean salinity for Julington Creek at Hood Landing near Bayard, Florida.

24. Hydrograph of daily mean tidally filtered discharge for Durbin Creek near Fruit Cove, Florida

25. Graph of daily maximum, minimum, and mean salinity for Durbin Creek near Fruit Cove, Florida.....

26. Hydrograph of daily mean discharge for Ortega River at Kirwin Road near Jacksonville, Florida.

27. Quantile plot of streamflow at Ortega River at Kirwin Road near Jacksonville, Florida.

28. Graph of daily maximum, minimum, and mean salinity for Ortega River salinity at Jacksonville, Florida.....

29. Hydrograph of daily mean tidally filtered discharge for Cedar River at San Juan Avenue at Jacksonville, Florida.

30. Graph of daily maximum, minimum, and mean salinity for Cedar River at San Juan Avenue at Jacksonville, Florida

31. Hydrograph of daily mean discharge for Pottsburg Creek near South Jacksonville, Florida .

32. Hydrograph of daily mean tidally filtered discharge for Pottsburg Creek at U.S. 90 near South Jacksonville, Florida.

33. Graph of daily maximum, minimum, and mean salinity for Pottsburg Creek at U.S. 90 near South Jacksonville, Florida

34. Hydrograph of daily mean tidally filtered discharge for Trout River near Jacksonville, Florida.

35. Graph of daily maximum, minimum, and mean salinity for Trout River below U.S. 1 at Dinsmore, Florida

36. Hydrograph of daily mean tidally filtered discharge for Broward River below Biscayne Boulevard near Jacksonville, Florida

37. Graph of daily maximum, minimum, and mean salinity for Broward River below Biscayne Boulevard near Jacksonville, Florida

38. Hydrograph of daily mean tidally filtered discharge for Dunn Creek at Dunn Creek Road near Eastport, Florida. 
39. Graph of daily maximum, minimum, and mean salinity for Dunn Creek at Dunn Creek Road near Eastport, Florida.....

40. Hydrograph of daily mean tidally filtered discharge for Clapboard Creek near Jacksonville, Florida.

41. Graph of daily maximum, minimum, and mean salinity for Clapboard Creek above Buckhorn Bluff near Jacksonville, Florida

42. Hydrograph of instantaneous discharge during Hurricane Matthew at St. Johns River at Jacksonville, Florida

43. Graph of instantaneous salinity during Hurricane Matthew at St. Johns River at Jacksonville, Florida.

44. Hydrograph of instantaneous discharge during Hurricane Matthew at Cedar River at San Juan Avenue at Jacksonville, Florida

45. Graph of instantaneous salinity during Hurricane Matthew at Cedar River at San Juan Avenue at Jacksonville, Florida

46. Graph of instantaneous discharge during Hurricane Irma at St. Johns River at Jacksonville, Florida . .31

47. Graph of instantaneous discharge during Hurricane Irma at Ortega River at Kirwin Road near Jacksonville, Florida .

48. Graph of instantaneous salinity during Hurricane Irma at St. Johns River at

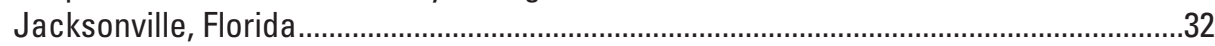

49. Graph of annual mean discharge at St. Johns River main-stem monitoring sites ..........32

50. Graph of annual mean discharge at St. Johns River tributary monitoring sites ..............33

51. Graph of annual rainfall for Duval, Putnam, and Volusia Counties for 2016 and 2017 water years ....33

52. Graph of annual mean salinity at St. Johns River main-stem monitoring sites ................34

53. Graph of annual mean salinity at St. Johns River tributary monitoring sites ...................34

\section{Table}

1. U.S. Geological Survey data collection sites on the main stem of the St. Johns River and its tributaries and parameters published during the 2017 water year..... 


\section{Conversion Factors}

U.S. customary units to International System of Units

\begin{tabular}{|c|c|c|}
\hline Multiply & By & To obtain \\
\hline \multicolumn{3}{|c|}{ Length } \\
\hline inch (in.) & 2.54 & centimeter $(\mathrm{cm})$ \\
\hline foot $(\mathrm{ft})$ & 0.3048 & meter $(\mathrm{m})$ \\
\hline mile (mi) & 1.609 & kilometer $(\mathrm{km})$ \\
\hline \multicolumn{3}{|c|}{ Flow rate } \\
\hline cubic foot per second $\left(\mathrm{ft}^{3} / \mathrm{s}\right)$ & 0.02832 & cubic meter per second $\left(\mathrm{m}^{3} / \mathrm{s}\right)$ \\
\hline
\end{tabular}

Temperature in degrees Celsius $\left({ }^{\circ} \mathrm{C}\right)$ may be converted to degrees Fahrenheit $\left({ }^{\circ} \mathrm{F}\right)$ as follows: ${ }^{\circ} \mathrm{F}=\left(1.8 \times{ }^{\circ} \mathrm{C}\right)+32$.

\section{Datum}

Vertical coordinate information is referenced to the North American Vertical Datum of 1988 (NAVD 88).

Horizontal coordinate information is referenced to the North American Datum of 1983 (NAD 83).

\section{Supplemental Information}

Specific conductance is given in microsiemens per centimeter at 25 degrees Celsius ( $\mu \mathrm{S} / \mathrm{cm}$ at $\left.25^{\circ} \mathrm{C}\right)$.

\section{Abbreviations}

$\begin{array}{ll}\text { FDEP } & \text { Florida Department of Environmental Protection } \\ \text { ppt } & \text { parts per thousand } \\ \text { PVC } & \text { polyvinyl chloride } \\ \text { SJRWMD } & \text { St. Johns River Water Management District } \\ \text { USACE } & \text { U.S. Army Corps of Engineers } \\ \text { USGS } & \text { U.S. Geological Survey }\end{array}$




\title{
Continuous Stream Discharge, Salinity, and Associated Data Collected in the Lower St. Johns River and Its Tributaries, Florida, 2017
}

\author{
By Patrick J. Ryan
}

\section{Abstract}

The U.S. Army Corps of Engineers, Jacksonville District, plans to deepen the St. Johns River channel in Jacksonville, Florida, from 40 to 47 feet along 13 miles of the river channel, beginning at the mouth of the river at the Atlantic Ocean, to accommodate larger, fully loaded cargo vessels. The U.S. Geological Survey, in cooperation with the U.S. Army Corps of Engineers, (1) installed continuous data collection stations to monitor discharge, salinity, and associated parameters at 23 sites prior to the commencement of dredging and (2) monitored stage and discharge at 13 sites and water temperature, specific conductance, and salinity at 16 sites; all parameters were monitored at some sites.

This is the second annual report by the U.S. Geological Survey on data collection for the Jacksonville Harbor deepening and contains information pertinent to the data collection sites during the 2017 water year, from October 2016 to September 2017. One data collection site on the St. Johns River below Shands Bridge was added to the network during this timeframe after the previously monitored location was damaged by Hurricane Matthew.

Discharge and salinity varied widely during the data collection period, reflecting the effects of Hurricane Matthew in October 2016 and Hurricane Irma in September 2017. The annual mean discharge at Trout River was greatest among the tributaries, followed by annual mean discharges at Durbin Creek, Ortega River, Julington Creek, Pottsburg Creek, Clapboard Creek, Cedar River, Broward River, and Dunn Creek. Among the tributary sites, annual mean salinity was highest at the site closest to the Atlantic Ocean, Clapboard Creek, and lowest at the site farthest from the ocean, Durbin Creek. Annual mean salinity data from the main-stem sites on the St. Johns River indicate that salinity decreased with distance upstream from the ocean, which is expected. Relative to salinity for the 2016 water year, annual mean salinity in the tributaries was higher for the 2017 water year at four monitoring locations, lower at four monitoring locations, and the same at one location. Of the three sites where salinity was calculated on the main stem in the 2016 water year, salinity was higher at one monitoring location in the 2017 water year and lower at two locations.

\section{Introduction}

The St. Johns River flows 310 miles (mi) northward through the eastern half of Florida, through Jacksonville and into the Atlantic Ocean (fig. 1). The river consists of lakes, marshes, and seagrass beds, as well as the main river channel (herein referred to as the "main stem") that, near its mouth, can accommodate cruise ships and cargo vessels, with access to the Atlantic Ocean. Jacksonville Harbor is located along the first 20 river miles, beginning at the mouth of the St. Johns River where it empties into the Atlantic Ocean. Jacksonville Harbor currently can only accommodate small cargo vessels or large cargo vessels loaded below maximum capacity because of the authorized channel depth of 40 feet (ft). Dredging an additional $7 \mathrm{ft}$ will allow the port to accommodate larger, fully loaded vessels, and beginning at the mouth, the U.S. Army Corps of Engineers (USACE) plans to deepen the first 13 river miles (USACE, 2014).

Salinity models indicate that the harbor deepening may alter salinity in part of the study area, potentially causing salinity stress in some wetlands and to submerged aquatic vegetation, and changes in some fish and macroinvertebrate distributions (USACE, 2014). Environmental constraints required by permit include the collection of water temperature, salinity, and (or) stage, velocity, and streamflow data for at least 6 months prior to dredging, continuously throughout dredging, and for 10 years following dredging (Florida Department of Environmental Protection [FDEP], 2016). The U.S. Geological Survey (USGS), in cooperation with the USACE, is responsible for monitoring all parameters at the gage locations listed in the permit that were not already being monitored by other entities as of January 2016, the beginning of the initial data collection period (FDEP, 2016). This report describes the sites and briefly summarizes the data collected during the second year of the study, from October 2016 to September 2017. The first year of the study is described in Ryan (2018).

The streamflow and water-quality monitoring network was used to collect baseline data in the St. Johns River and its tributaries prior to dredging and will be used to discern changes, if any, during and after dredging. This report provides an overview of the data collected from 23 surface-water 


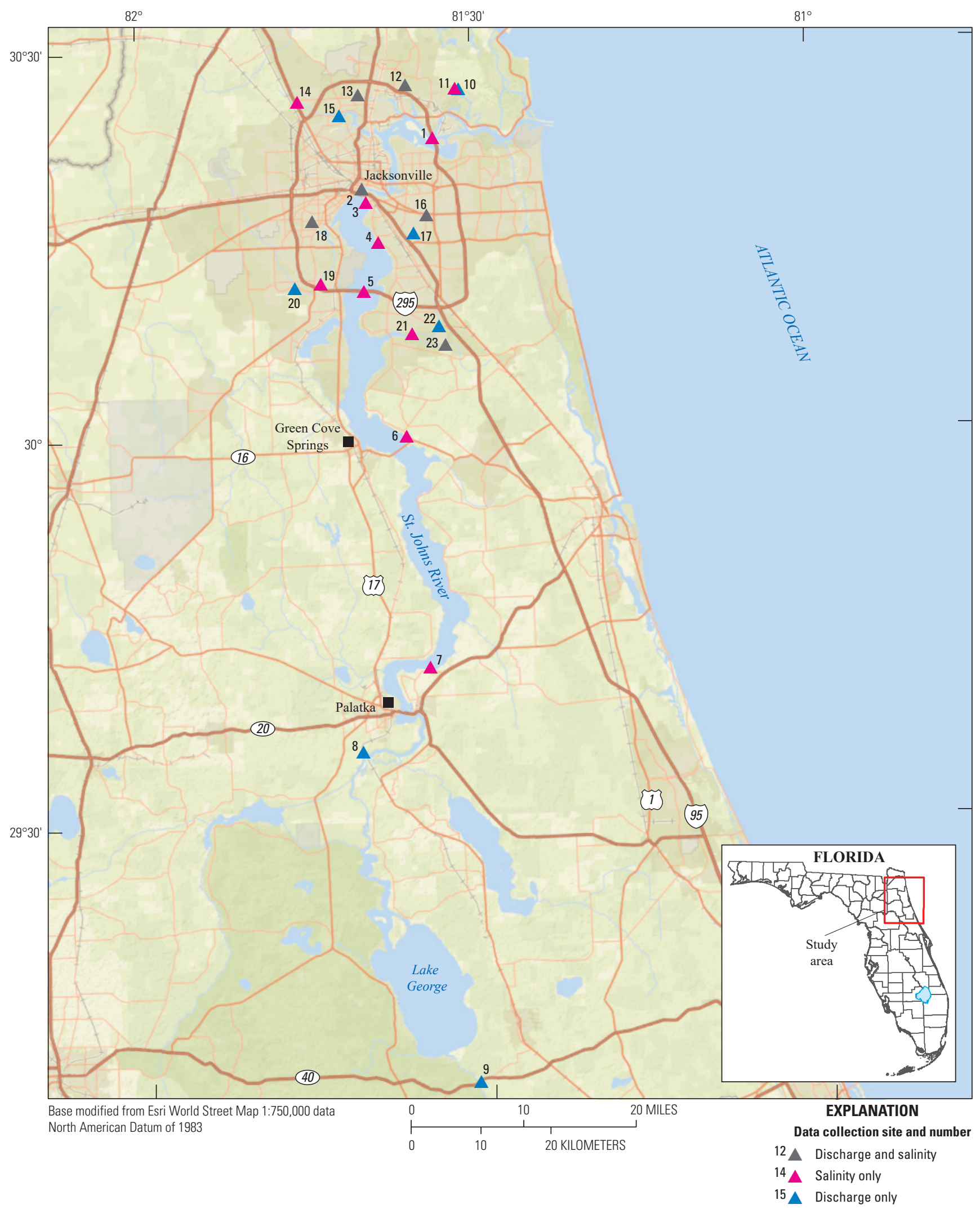

Figure 1. U.S. Geological Survey data collection sites on the St. Johns River and its tributaries. Map image is the intellectual property of Esri and is used herein under license. Copyright (c) 2019 Esri and its licensors. All rights reserved. 
discharge and (or) water-quality sites along the St. Johns River and its tributaries under predredging conditions during the 2017 water year, from October 2016 to September 2017 (figs. 1 and 2). The report documents the data collection sites, methods used to compute discharge and salinity, and parameters monitored at each site. The data collected during this study are available from the USGS National Water Information System database (U.S. Geological Survey, 2019).

\section{Methods}

The methods of data collection and processing, as well as the sites used for data collection, are described in the following sections. The descriptions of data collection sites are separated into those along the St. Johns River and those along tributaries of the St. Johns River (table 1).

\section{Methods of Data Collection and Processing}

Stage data (gage height, in feet, referenced to the North American Vertical Datum of 1988) were collected at 15-minute intervals by using various types of equipment, depending on location requirements, in accordance with USGS standards (Sauer and Turnipseed, 2010). Discharge was routinely measured by using various types of equipment, depending on depth, velocity, and environmental conditions, in accordance with USGS standards (Turnipseed and Sauer, 2010). Because of tidal and (or) wind effects, discharge, in cubic feet per second, was computed by using the index-velocity method at most sites, in accordance with USGS techniques and methods (Levesque and Oberg, 2012). The index-velocity method was used to calculate discharge unless otherwise specified in this report. Discharge was computed by using a stage-discharge relationship at a few sites where tidal influence was not substantial (Rantz and others, 1982). Where applicable, discharge data were filtered by using the Godin low-pass filter to remove principal tidal frequencies from unit values. By convention, the USGS designates ebb (seaward) flow as positive flow and flood (landward) flow as negative flow. The residuals are not total freshwater flows, but instead, a combination of seaward freshwater flows from the watershed and landward saltwater flows from the marine environment, along with storm surges from hurricanes or tropical storms.

Water temperature, in degrees Celsius, and specific conductance, in microsiemens per centimeter at 25 degrees Celsius, were measured at intervals of 1 hour or less in accordance with USGS techniques and methods (Wagner and others, 2006). Water-quality meters were installed in situ at sites in freshwater environments and monitored at 15-minute intervals. A pump and intake system was installed at sites in harsh saltwater environments to reduce fouling. This setup consisted of a meter housed inside a polyvinyl chloride (PVC) chamber in a shelter. In this case, water was pumped into the chamber for 1 to 2 minutes before each measurement and drained from the chamber between measurements. The recording interval was reduced to one measurement per hour because of the power requirements for the pump setup. Because the chamber drains between measurements, water-quality parameters can be monitored at multiple levels with one meter, if necessary. A rating table was used to convert specific conductance, in microsiemens per centimeter, to salinity, in parts per thousand (Wagner and others, 2006). Salinity was calculated for every site where water temperature and specific conductance were measured.

Missing discharge data can usually be attributed to equipment malfunction, either by the stage sensor or velocity meter (if the index-velocity method is used). For tidally filtered discharge calculation, the Godin low-pass filter requires 35 hours of continuous data before and after each data point. A data gap greater than 2 hours, therefore, results in a data gap of 3 days in the tidally filtered discharge record. For sites that include a pump setup, missing water-quality data are usually a consequence of power or pump failure, which prevents water from filling the chamber in which the meter is housed. Biological fouling is a more common problem with meters installed in situ, where algal growth and crustaceans can affect the conductance measurement port or the temperature probe, both of which provide data used to calculate salinity. In either case, the affected values are not used, creating gaps in the final record.

Rainfall data for Duval, St. Johns, Putnam, and Volusia Counties in 2017 were obtained from the St. Johns River Water Management District (SJRWMD), which provides details about how average monthly rainfall data are compiled for counties in their district (http://webapub.sjrwmd.com/ agws 10/hydroreport/). Jacksonville Harbor and all monitoring sites included in this study are located within Duval County, except the St. Johns River sites at Astor in Volusia County, Dancy Point and Buffalo Bluff in Putnam County, and Shands Bridge in St. Johns County.

Quantile plots were created to show percentiles for annual discharge data collected at monitoring sites that have at least 10 years of record and a full contemporary year of data. The quantile plots group the annual peak discharges by water year. For this report, the 2017 water year includes data from October 1, 2016, to September 30, 2017. The resulting plots show how 2017 water year discharge at a given station compares with that of previous water years. For discharges affected by tidal fluctuations, annual mean tidally filtered discharge was used to construct the plot.

\section{Description of St. Johns River Main-Stem Sites}

All sites on the main stem of the St. Johns River have substantial tidal influence, and therefore the calculated discharge is tidally filtered. The farthest upstream discharge monitoring site on the St. Johns River is in Astor, Florida, at the State Road 40 Bridge (table 1; river mile 127). Approximately $37 \mathrm{mi}$ downstream, discharge is also calculated 


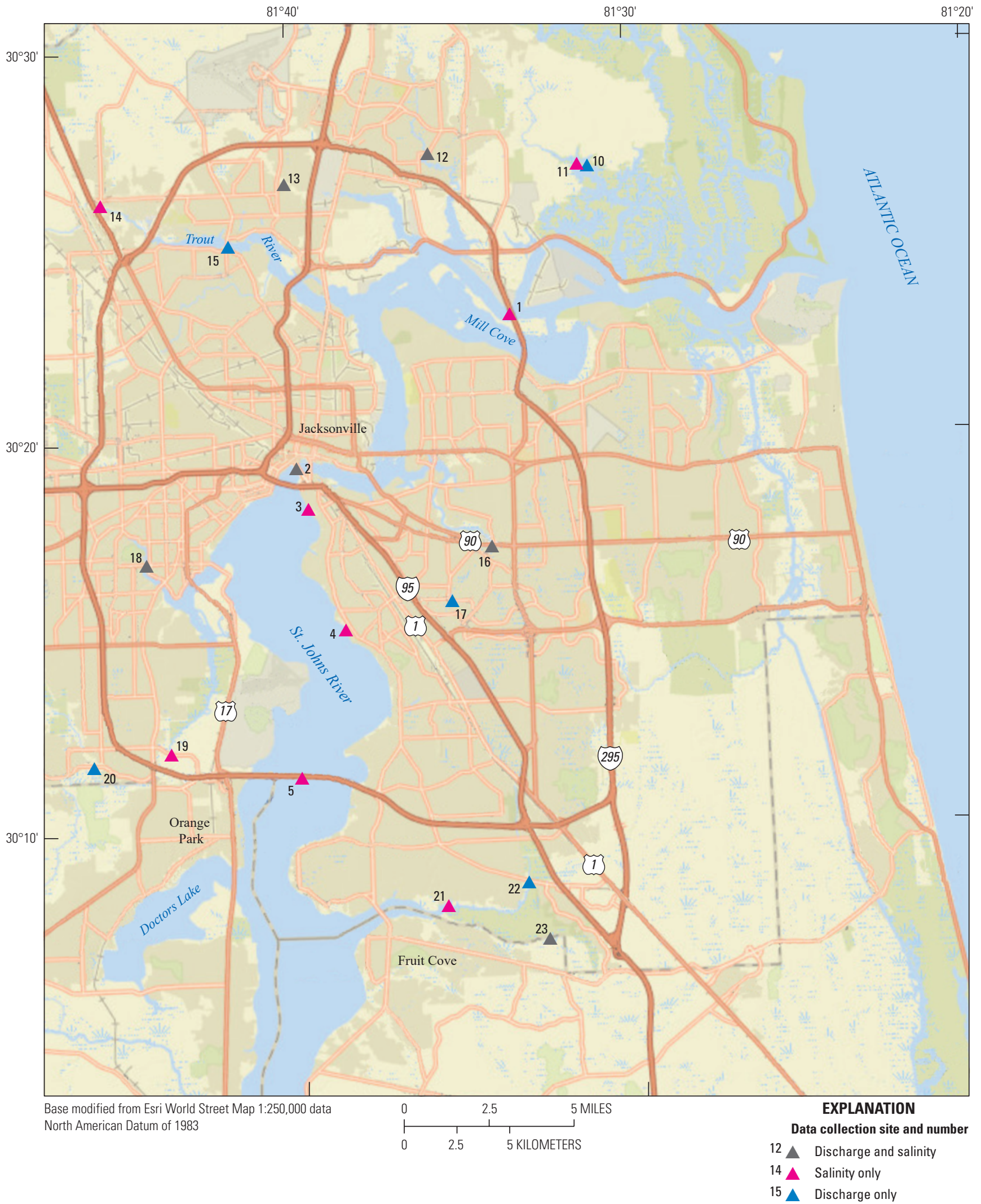

Figure 2. U.S. Geological Survey data collection sites in Duval County, Florida. Map image is the intellectual property of Esri and is used herein under license. Copyright (C) 2019 Esri and its licensors. All rights reserved. 
Table 1: U.S. Geological Survey data collection sites on the main stem of the St. Johns River and its tributaries and parameters published during the 2017 water year.

[USGS, U.S. Geological Survey; Fla., Florida; x, parameter measured; --, parameter not measured; NA, not applicable]

\begin{tabular}{|c|c|c|c|c|c|c|c|c|}
\hline $\begin{array}{l}\text { Map } \\
\text { number }\end{array}$ & $\begin{array}{l}\text { USGS } \\
\text { site number }\end{array}$ & $\begin{array}{l}\text { USGS } \\
\text { site name }\end{array}$ & Discharge & $\begin{array}{c}\text { Gage } \\
\text { height }\end{array}$ & Temperature & $\begin{array}{l}\text { Specific } \\
\text { conductance }\end{array}$ & Salinity & $\begin{array}{c}\text { River } \\
\text { mile }\end{array}$ \\
\hline \multicolumn{9}{|c|}{ St. Johns River } \\
\hline 1 & 302309081333001 & $\begin{array}{l}\text { St. Johns River Dames Point Bridge at } \\
\text { Jacksonville, Fla. }\end{array}$ & -- & -- & $\mathrm{x}$ & $\mathrm{x}$ & $\mathrm{x}$ & 10 \\
\hline 2 & 02246500 & St. Johns River at Jacksonville, Fla. & $\mathrm{x}$ & $\mathrm{x}$ & $\mathrm{x}$ & $\mathrm{x}$ & $\mathrm{x}$ & 23 \\
\hline 3 & 301817081393600 & $\begin{array}{l}\text { St. Johns River below Marco Lake at } \\
\text { Jacksonville, Fla. }\end{array}$ & -- & -- & $\mathrm{x}$ & $\mathrm{x}$ & $\mathrm{x}$ & 25 \\
\hline 4 & 301510081383500 & $\begin{array}{l}\text { St. Johns River at Christopher Point } \\
\text { near Jacksonville, Fla. }\end{array}$ & -- & -- & $\mathrm{x}$ & $\mathrm{x}$ & $\mathrm{x}$ & 29 \\
\hline 5 & 301124081395901 & $\begin{array}{l}\text { St. Johns River Buckman Bridge at } \\
\text { Jacksonville, Fla. }\end{array}$ & -- & -- & $\mathrm{x}$ & $\mathrm{x}$ & $\mathrm{x}$ & 34 \\
\hline 6 & 02245340 & $\begin{array}{l}\text { St. Johns River below Shands Bridge } \\
\text { near Green Cove Springs, Fla. }\end{array}$ & -- & $\mathrm{x}$ & $\mathrm{x}$ & $\mathrm{x}$ & $\mathrm{x}$ & 49 \\
\hline 7 & 294213081345300 & $\begin{array}{l}\text { St. Johns River at Dancy Point near } \\
\text { Spuds, Fla. }\end{array}$ & -- & -- & $\mathrm{x}$ & $\mathrm{x}$ & $\mathrm{x}$ & 71 \\
\hline 8 & 02244040 & $\begin{array}{l}\text { St. Johns River at Buffalo Bluff near } \\
\text { Satsuma, Fla. }\end{array}$ & $\mathrm{x}$ & $\mathrm{x}$ & -- & -- & -- & 90 \\
\hline 9 & 02236125 & St. Johns River at Astor, Fla. & $\mathrm{x}$ & $\mathrm{x}$ & -- & -- & -- & 127 \\
\hline \multicolumn{9}{|c|}{$\begin{array}{ll}\text { Tributaries } \\
\end{array}$} \\
\hline 10 & 02246825 & Clapboard Creek near Jacksonville, Fla. & $\mathrm{x}$ & $\mathrm{x}$ & -- & -- & -- & NA \\
\hline 11 & 302657081312400 & $\begin{array}{l}\text { Clapboard Creek above Buckhorn Bluff } \\
\text { near Jacksonville, Fla. }\end{array}$ & -- & -- & $\mathrm{x}$ & $\mathrm{x}$ & $\mathrm{x}$ & NA \\
\hline 12 & 02246804 & $\begin{array}{l}\text { Dunn Creek at Dunn Creek Road near } \\
\text { Eastport, Fla. }\end{array}$ & $\mathrm{x}$ & $\mathrm{x}$ & $\mathrm{x}$ & $\mathrm{x}$ & $\mathrm{x}$ & NA \\
\hline 13 & 02246751 & $\begin{array}{l}\text { Broward River below Biscayne Blvd } \\
\text { near Jacksonville, Fla. }\end{array}$ & $\mathrm{x}$ & $\mathrm{x}$ & $\mathrm{x}$ & $\mathrm{x}$ & $\mathrm{x}$ & NA \\
\hline 14 & 302609081453300 & $\begin{array}{l}\text { Trout River below U.S. } 1 \text { at } \\
\text { Dinsmore, Fla. }\end{array}$ & -- & -- & $\mathrm{x}$ & $\mathrm{x}$ & $\mathrm{x}$ & NA \\
\hline 15 & 02246621 & Trout River near Jacksonville, Fla. & $\mathrm{x}$ & $\mathrm{x}$ & -- & -- & -- & NA \\
\hline 16 & 02246518 & $\begin{array}{l}\text { Pottsburg Creek at U.S. } 90 \text { near South } \\
\text { Jacksonville, Fla. }\end{array}$ & $\mathrm{x}$ & $\mathrm{x}$ & $\mathrm{x}$ & $\mathrm{x}$ & $\mathrm{x}$ & NA \\
\hline 17 & 02246515 & $\begin{array}{l}\text { Pottsburg Creek near South } \\
\text { Jacksonville, Fla. }\end{array}$ & $\mathrm{x}$ & $\mathrm{x}$ & -- & -- & -- & NA \\
\hline 18 & 02246459 & $\begin{array}{l}\text { Cedar River at San Juan Avenue at } \\
\text { Jacksonville, Fla. }\end{array}$ & $\mathrm{x}$ & $\mathrm{x}$ & $\mathrm{x}$ & $\mathrm{x}$ & $\mathrm{x}$ & NA \\
\hline 19 & 301204081434900 & $\begin{array}{l}\text { Ortega River Salinity at } \\
\text { Jacksonville, Fla. }\end{array}$ & -- & -- & $\mathrm{x}$ & $\mathrm{x}$ & $\mathrm{x}$ & NA \\
\hline 20 & 02246318 & $\begin{array}{l}\text { Ortega River at Kirwin Road near } \\
\text { Jacksonville, Fla. }\end{array}$ & $\mathrm{x}$ & $\mathrm{x}$ & -- & -- & -- & NA \\
\hline 21 & 300803081354500 & $\begin{array}{l}\text { Julington Creek at Hood Landing near } \\
\text { Bayard, Fla. }\end{array}$ & -- & -- & $\mathrm{x}$ & $\mathrm{x}$ & $\mathrm{x}$ & NA \\
\hline 22 & 02246160 & $\begin{array}{l}\text { Julington Creek at Old St August Road } \\
\text { near Bayard, Fla. }\end{array}$ & $\mathrm{x}$ & $\mathrm{x}$ & -- & -- & -- & NA \\
\hline 23 & 022462002 & Durbin Creek near Fruit Cove, Fla. & $\mathrm{x}$ & $\mathrm{x}$ & $\mathrm{x}$ & $\mathrm{x}$ & $\mathrm{x}$ & NA \\
\hline
\end{tabular}


for the St. Johns River at Buffalo Bluff (river mile 90). Both sites are monitored in cooperation with the SJRWMD. Tidally filtered discharge values have been computed since 1994 for both Astor and Buffalo Bluff. The farthest upstream water-quality monitoring station along the St. Johns River is located at Dancy Point (river mile 71). Water temperature and specific conductance are measured at an approximate depth of $11.5 \mathrm{ft}$ below the average high-tide level. A monitoring station was installed on the St. Johns River below Shands Bridge (river mile 49) in June 2017 after the original station was destroyed by Hurricane Matthew. Stage is measured at this station, as well as water temperature and specific conductance at an approximate depth of $8.5 \mathrm{ft}$ below the average high-tide level.

A monitoring station at Buckman Bridge (river mile 34) measures water temperature and specific conductance with separate pump setups and intakes at two different depths. One water-quality meter is used in the chamber and monitors both water properties at each depth. The chamber is drained completely between measurements. Calculation of salinity began in October 2016. All water-quality parameters are monitored at approximate depths of $8 \mathrm{ft}$ (top) and $16 \mathrm{ft}$ (bottom) below the average high-tide level. Water-quality monitoring stations at Christopher Point (river mile 29) and Marco Lake (river mile 25) measure water temperature and specific conductance at an approximate depth of $4 \mathrm{ft}$ below the average high-tide level at each location. These sites are characterized by relatively shallow water having an average depth of less than $6 \mathrm{ft}$ and represent river conditions in seagrass beds near the shore.

The St. Johns River at Jacksonville, Florida, data collection station, located near downtown Jacksonville at Acosta Bridge (river mile 23), is the farthest downstream gage that calculates discharge. Stage and discharge were monitored before the dredging study began, and water temperature and specific conductance data collection began in October 2015 at an approximate depth of $11 \mathrm{ft}$ below the average high-tide level. Tidally filtered discharge values have been computed since 1996. A monitoring station at Dames Point Bridge in Jacksonville (river mile 10) measures water temperature and specific conductance; calculation of salinity began in October 2016. All water-quality data are collected at approximate depths of $15 \mathrm{ft}$ (top) and $22 \mathrm{ft}$ (bottom) below the average high-tide level by using one water-quality meter and pump setup with separate intakes, similar to the station at Buckman Bridge.

\section{Description of Tributary Sites}

A monitoring station on Julington Creek at Old St. Augustine Road calculates discharge $6.7 \mathrm{mi}$ upstream from the confluence of Julington Creek and the St. Johns River (table 1). A nearby water-quality monitoring station measures water temperature and specific conductance at an approximate depth of $3.5 \mathrm{ft}$ below the average high-tide level and is located approximately $3 \mathrm{mi}$ downstream from Old St. Augustine Road on Julington Creek, at Hood Landing.

Durbin Creek is monitored for stage, discharge, water temperature, specific conductance, and salinity $3.5 \mathrm{mi}$ upstream from its confluence with Julington Creek and $6.8 \mathrm{mi}$ upstream from its confluence with the St. Johns River. The water-quality parameters are monitored at an approximate depth of $3 \mathrm{ft}$ below the average high-tide level. These locations are all tidally influenced, but large amounts of rainfall and resulting increases in discharge can obscure the tidal signal.

Ortega River is monitored for stage and discharge at Argyle Forest Boulevard (Kirwin Road), 11 mi upstream from the confluence of the Ortega and St. Johns Rivers. Discharge has been computed intermittently at this location since 2002, and a stage-discharge rating was used for discharge computation during the study period, as no tidal influence is apparent in the stage data. A water-quality monitoring station that measures water temperature and specific conductance at an approximate depth of $6.5 \mathrm{ft}$ below the average high-tide level is located at the bridge on Collins Road approximately 3 mi downstream from Kirwin Road on the Ortega River. Tidal influence is evident in the salinity data during times of low flow or increased stage in the St. Johns River.

The monitoring station on Cedar River measures stage, water temperature, and specific conductance at San Juan Avenue, $1.5 \mathrm{mi}$ upstream from the confluence of the Cedar and St. Johns Rivers. The water-quality parameters are monitored at an approximate depth of $6 \mathrm{ft}$ below the average high-tide level. Historical, tidally filtered discharge values have been computed intermittently since 2002 . Wind, tide, and rainfall all substantially affect flow and salinity at Cedar River, and vertically stratified, bidirectional flow is commonly measured when strong winds occur opposite the direction of flow.

The station at Pottsburg Creek near South Jacksonville measures stage and is $7.3 \mathrm{mi}$ upstream from the confluence of Pottsburg Creek and the St. Johns River. A stage-discharge rating was used for discharge computation during the study period. The data indicate tidal influence when stage is very low in the creek and elevated in the St. Johns River, but discharge measurements confirm the validity of the stage-discharge relationship. Pottsburg Creek is monitored for stage, discharge, water temperature, specific conductance, and salinity at U.S. 90, 5.2 mi upstream from the confluence of Pottsburg Creek and the St. Johns River. The water-quality parameters are monitored at an approximate depth of $4 \mathrm{ft}$ below the average high-tide level. This location has a more pronounced tidal signal, and discharge and salinity are affected primarily by rainfall and elevated stage in the river.

The monitoring station for Trout River calculates discharge at Lem Turner Road, 5 mi upstream from the confluence of the Trout and St. Johns Rivers. Water temperature and specific conductance are measured $9.3 \mathrm{mi}$ upstream from the confluence at an approximate depth of $6 \mathrm{ft}$ below the average high-tide level. Broward River is monitored for stage, discharge, water temperature, specific conductance, and salinity near Biscayne Boulevard, $6.3 \mathrm{mi}$ upstream from its confluence with the St. Johns River. The water-quality parameters are monitored at an approximate depth of $4.5 \mathrm{ft}$ below the average high-tide level. Discharge and salinity at these stations have a pronounced tidal signal, even when stage is elevated.

Dunn Creek is monitored for stage, discharge, water temperature, specific conductance, and salinity at Dunn Creek 
Road, 5.3 mi upstream from the confluence of Dunn Creek and the St. Johns River. The monitoring station for Clapboard Creek calculates discharge near Sheffield Road, $4.5 \mathrm{mi}$ upstream from the confluence of Clapboard Creek and the St. Johns River. Water temperature and specific conductance are measured at a location $0.5 \mathrm{mi}$ upstream. The water-quality parameters are monitored at an approximate depth of $6.5 \mathrm{ft}$ below the average high-tide level. Discharge and salinity fluctuations at these sites are dependent on rainfall in the relatively small drainage area and on wind effects from the St. Johns River, owing to the proximity of the sites to the river and Atlantic Ocean.

\section{Results}

Because of the large project area and diversity of sites, discharge and salinity varied widely during the period. As expected, salinities were lowest at the tributary sites farthest from the ocean and highest during periods of low flow in the St. Johns River. Duval County rainfall was above the long-term average for 7 of the 12 months from October 2016 to September 2017. Rainfall for Duval County during this period ranged from 2.5 inches (in.) below average in March to 5.6 in. above average in September, and the total annual rainfall was $11.6 \mathrm{in}$. above average based on rainfall data from SJRWMD (2018). Rainfall in Duval County was 12.4 in. above average for the typically wetter months of May to September and $0.7 \mathrm{in}$. below average for the typically drier months of October to April. Rainfall for Volusia, Putnam, and St. Johns Counties was similar, totaling 4.0, 11.2, and 7.6 in. above the average yearly total, respectively (SJRWMD, 2018). The 2017 water year and average monthly rainfall totals for each county are shown in figures 3-6.

Daily discharge and salinity plots for the 2017 water year (October 2016-September 2017) are presented in the following sections where applicable. A year is referenced in these sections as a water year unless otherwise noted. Daily discharge is tidally filtered at sites where substantial tidal

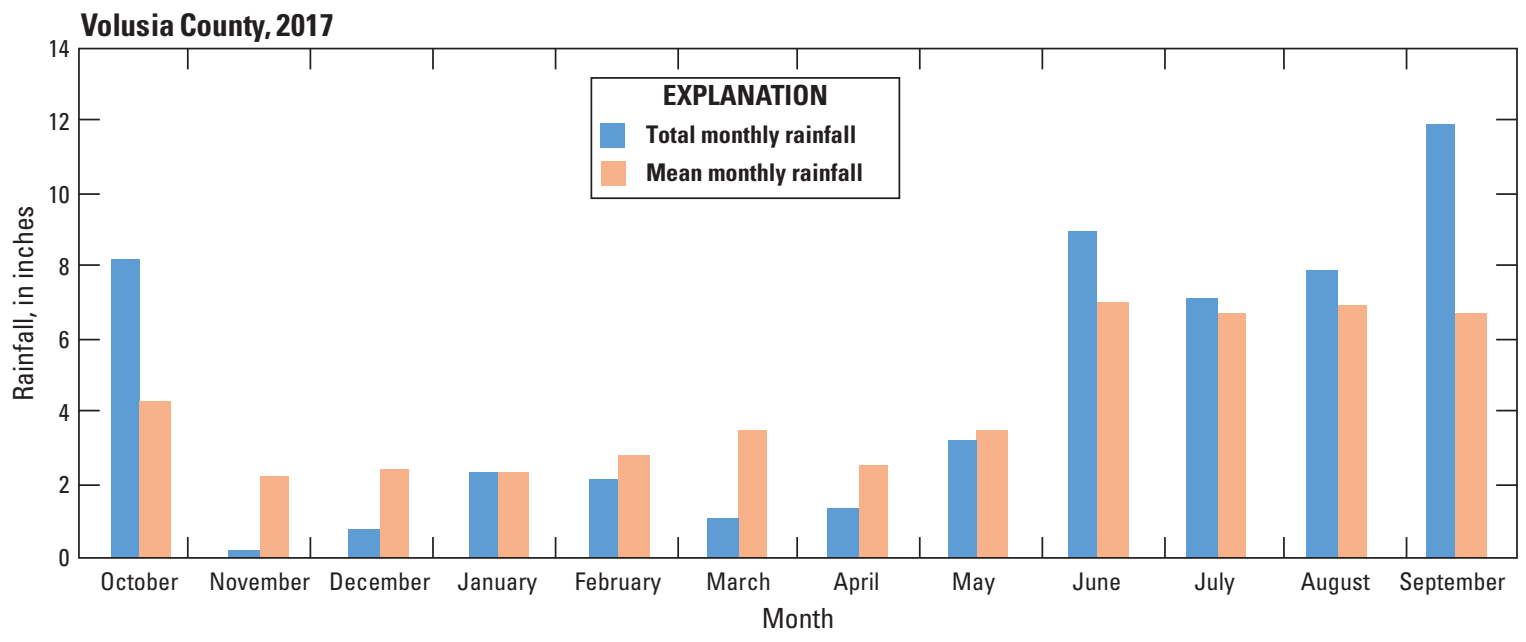

Figure 3. Graph showing 2017 water year monthly rainfall and mean monthly rainfall for Volusia County (St. Johns River Water Management District [SJRWMD], 2018).

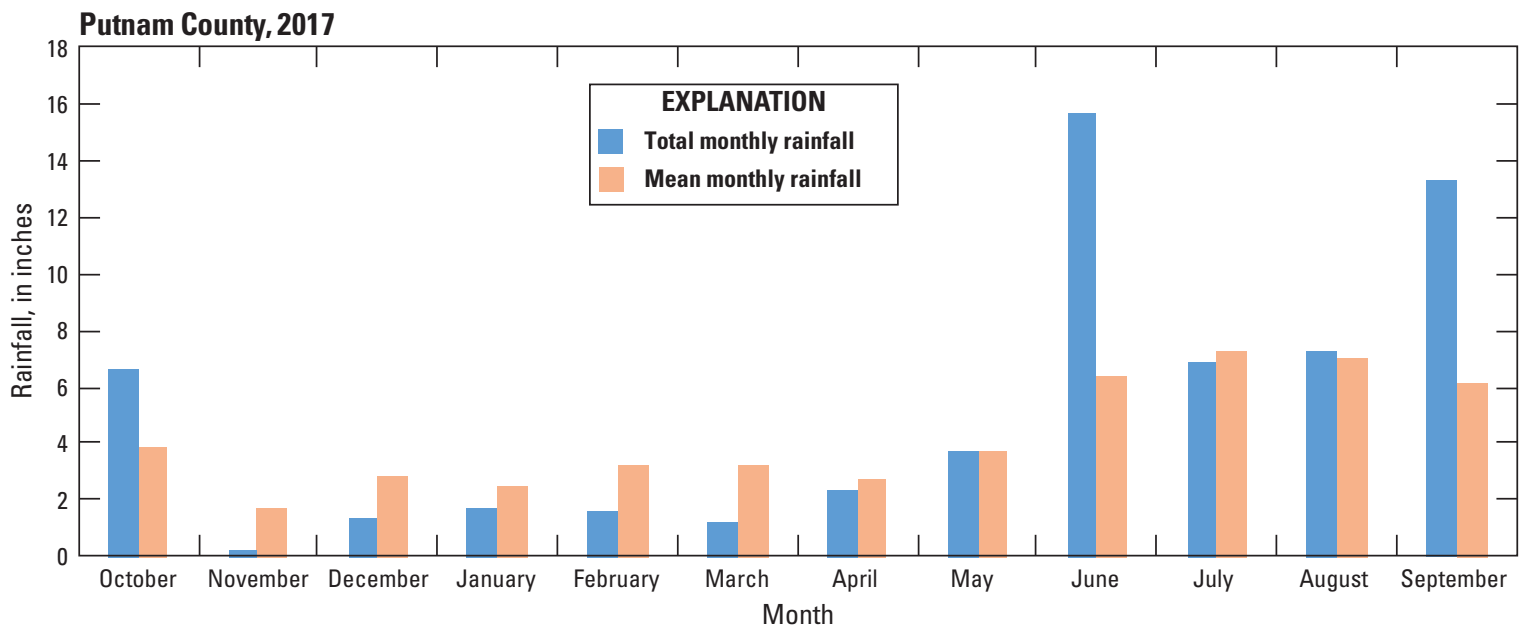

Figure 4. Graph showing 2017 water year monthly rainfall and mean monthly rainfall for Putnam County (St. Johns River Water Management District [SJRWMD], 2018). 


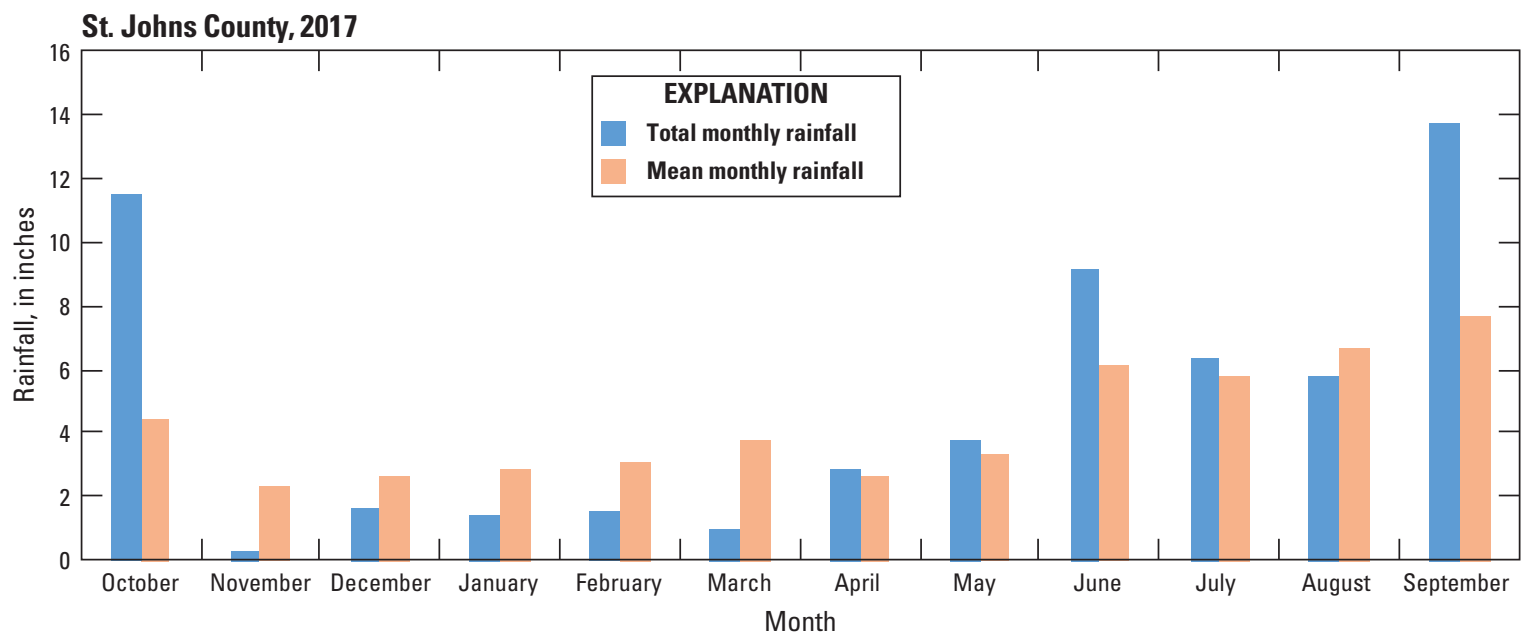

Figure 5. Graph showing 2017 water year monthly rainfall and mean monthly rainfall for St. Johns County (St. Johns River Water Management District [SJRWMD], 2018).

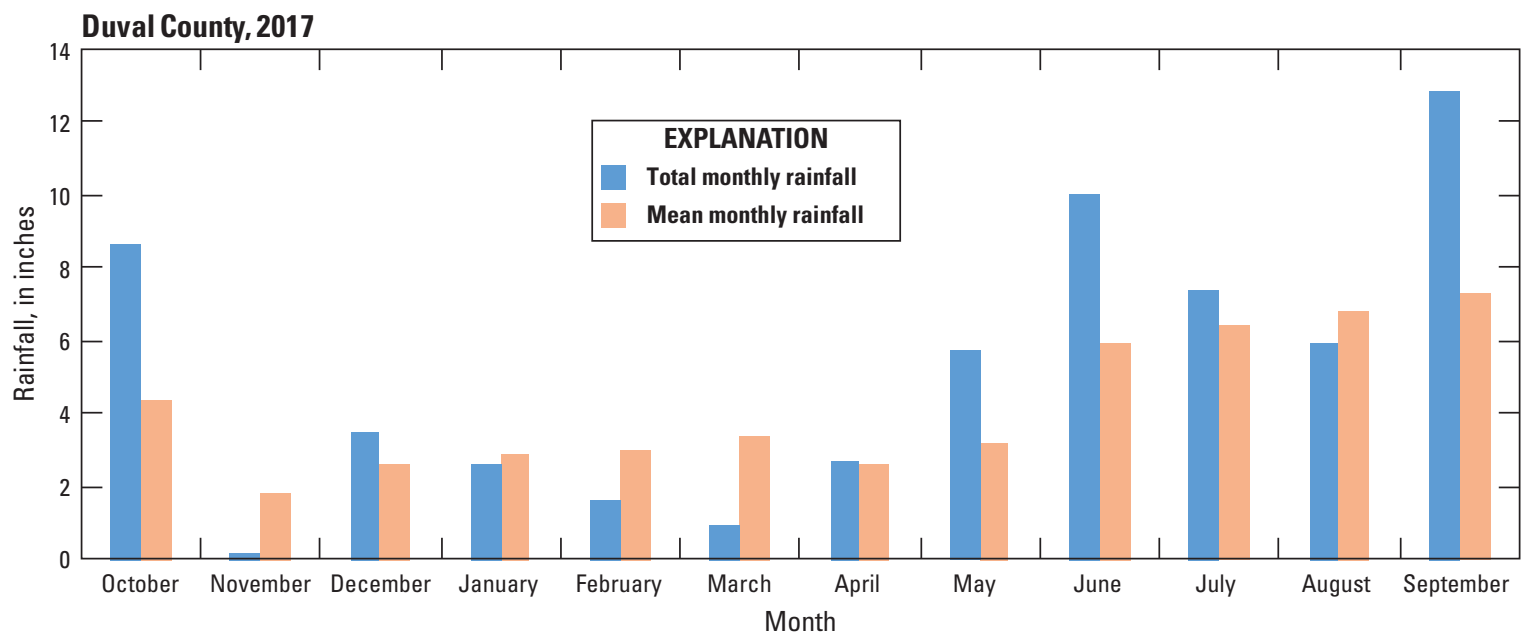

Figure 6. Graph showing 2017 water year monthly rainfall and mean monthly rainfall for Duval County (St. Johns River Water Management District [SJRWMD], 2018).

fluctuations occur. Salinity values are not filtered and include daily maximum, minimum, and mean values. Instantaneous values can be accessed from the USGS National Water Information System database (U.S. Geological Survey, 2019). Annual mean discharges are calculated only for sites having at least an entire year of discharge record. The annual mean is not calculated for partial years of record when stations were installed.

\section{Main-Stem Sites}

St. Johns River at Astor, Florida - Daily tidally filtered discharge at Astor ranged from -7,330 to 12,600 (estimated) cubic feet per second $\left(\mathrm{ft}^{3} / \mathrm{s}\right)$ during the 2017 water year (fig. 7), with an annual mean of 2,660 ft3 $/ \mathrm{s}$. Tidally filtered discharge was estimated for 7 days in September 2017 because of debris interference with the equipment. A comparison of historical annual mean tidally filtered flows indicated that the 2017 streamflow is at the 37 th percentile; the median tidally filtered flow for the period of record is $2,780 \mathrm{ft}^{3} / \mathrm{s}$ (fig. 8). The annual mean flow for 1994 was not used in the quantile plot, because the period of record for that year begins in February. The subsequent 23 years of discharge record were, therefore, used to construct the quantile plot.

St. Johns River at Buffalo Bluff Near Satsuma, Florida -Daily tidally filtered discharge at Buffalo Bluff ranged from $-29,800$ to $25,700 \mathrm{ft}^{3} / \mathrm{s}$ during the 2017 water year, with an annual mean of $4,150 \mathrm{ft}^{3} / \mathrm{s}$ (fig. 9). This large range in discharge is a result of the effects of storm surge from Hurricane Matthew in October 2016 and rainfall from Hurricane Irma in September 2017. No tidally filtered discharges were computed for 7 days in September because of equipment damage caused by Hurricane Irma. The missing data occurred during a period of increasing discharge before the peak and could have influenced the percentile rank, but this effect is assumed to be small enough to allow the calculation and use of annual mean flow. A comparison of historical annual mean tidally filtered flows indicated that the 2017 streamflow is at the 44th percentile; the median tidally filtered flow for the period of record is $4,290 \mathrm{ft}^{3} / \mathrm{s}$ (fig. 10). 


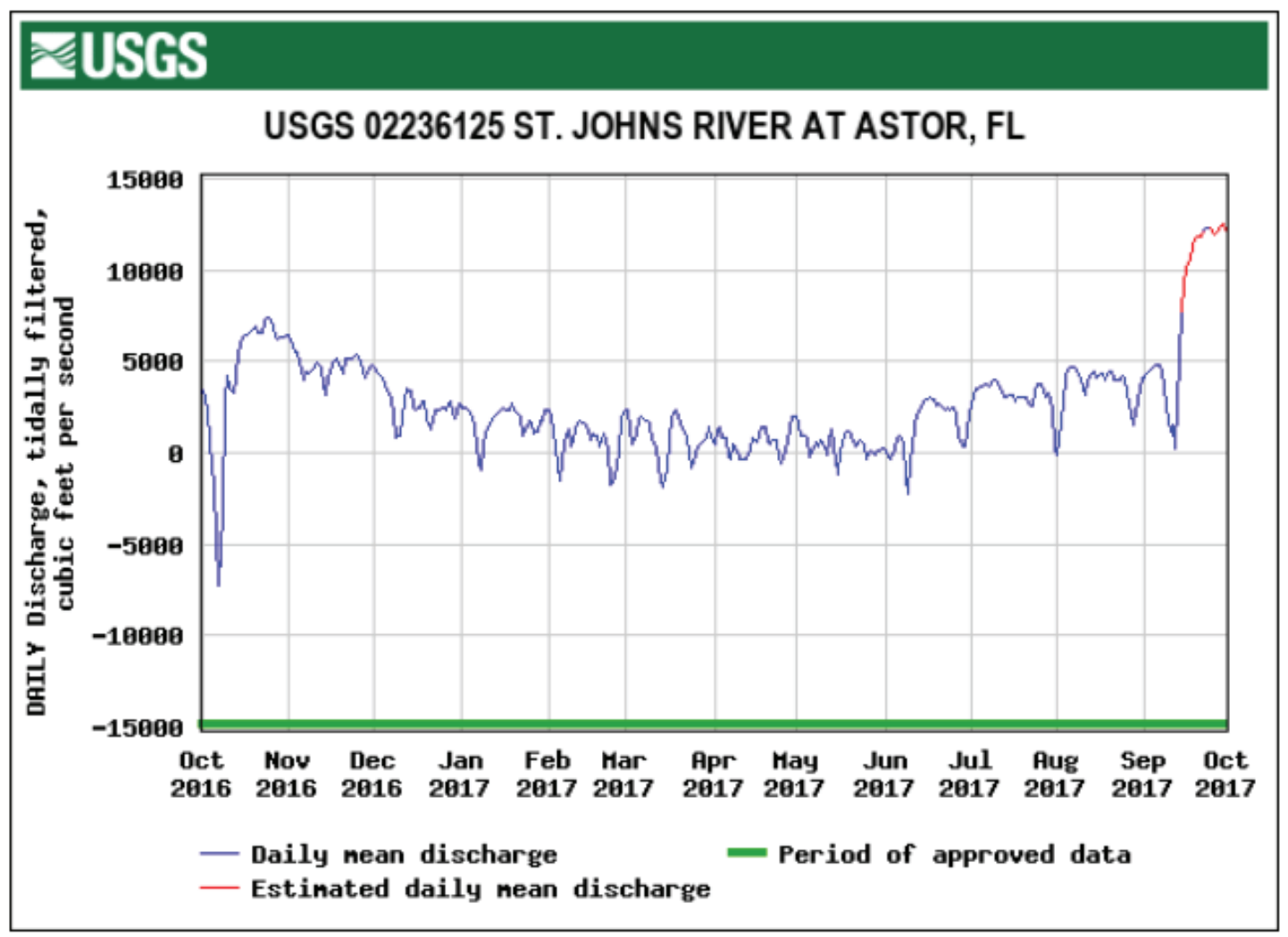

Figure 7. Daily mean tidally filtered discharge for St. Johns River at Astor, Florida.

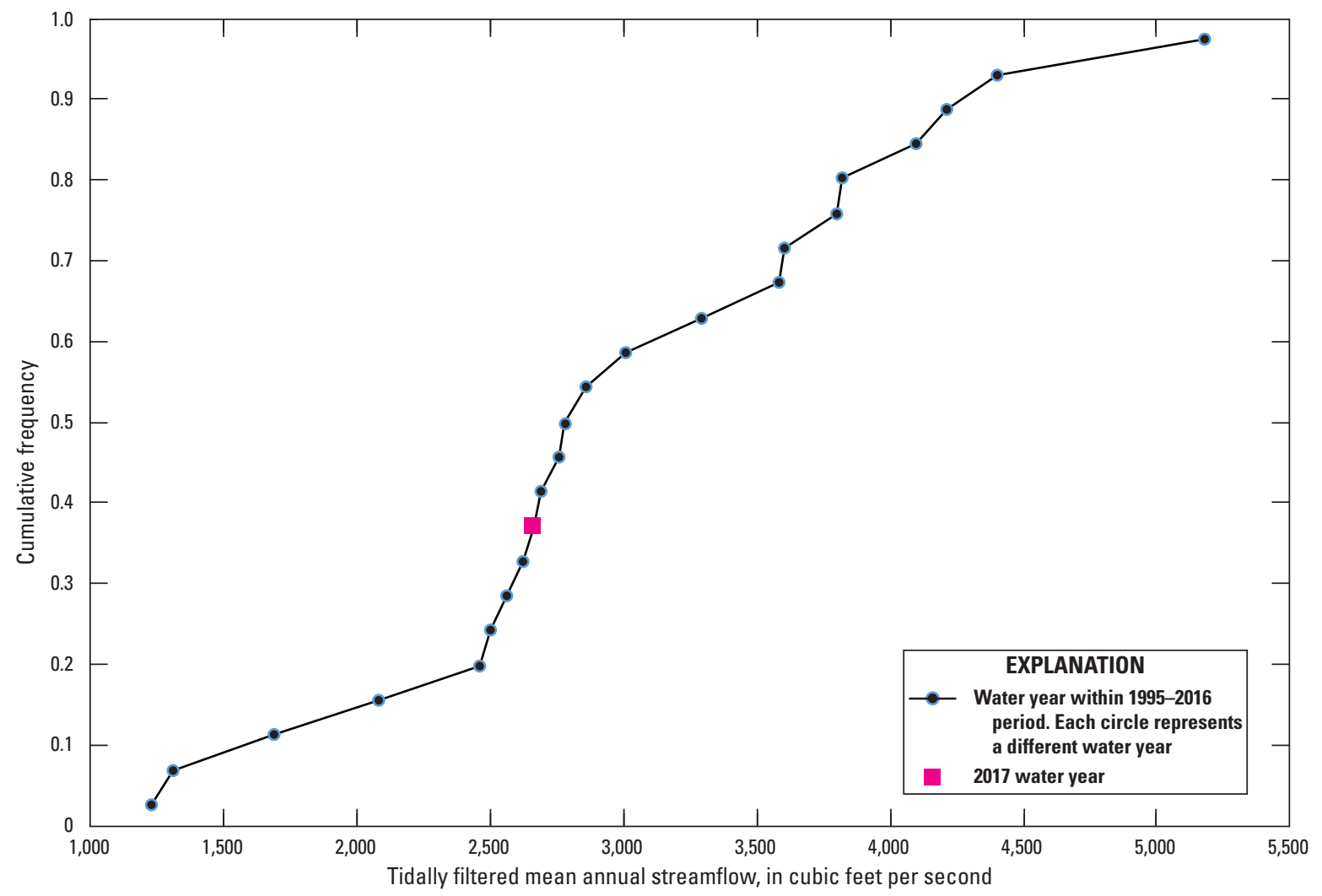

Figure 8. Annual mean tidally filtered streamflow data for St. Johns River at Astor, Florida. 


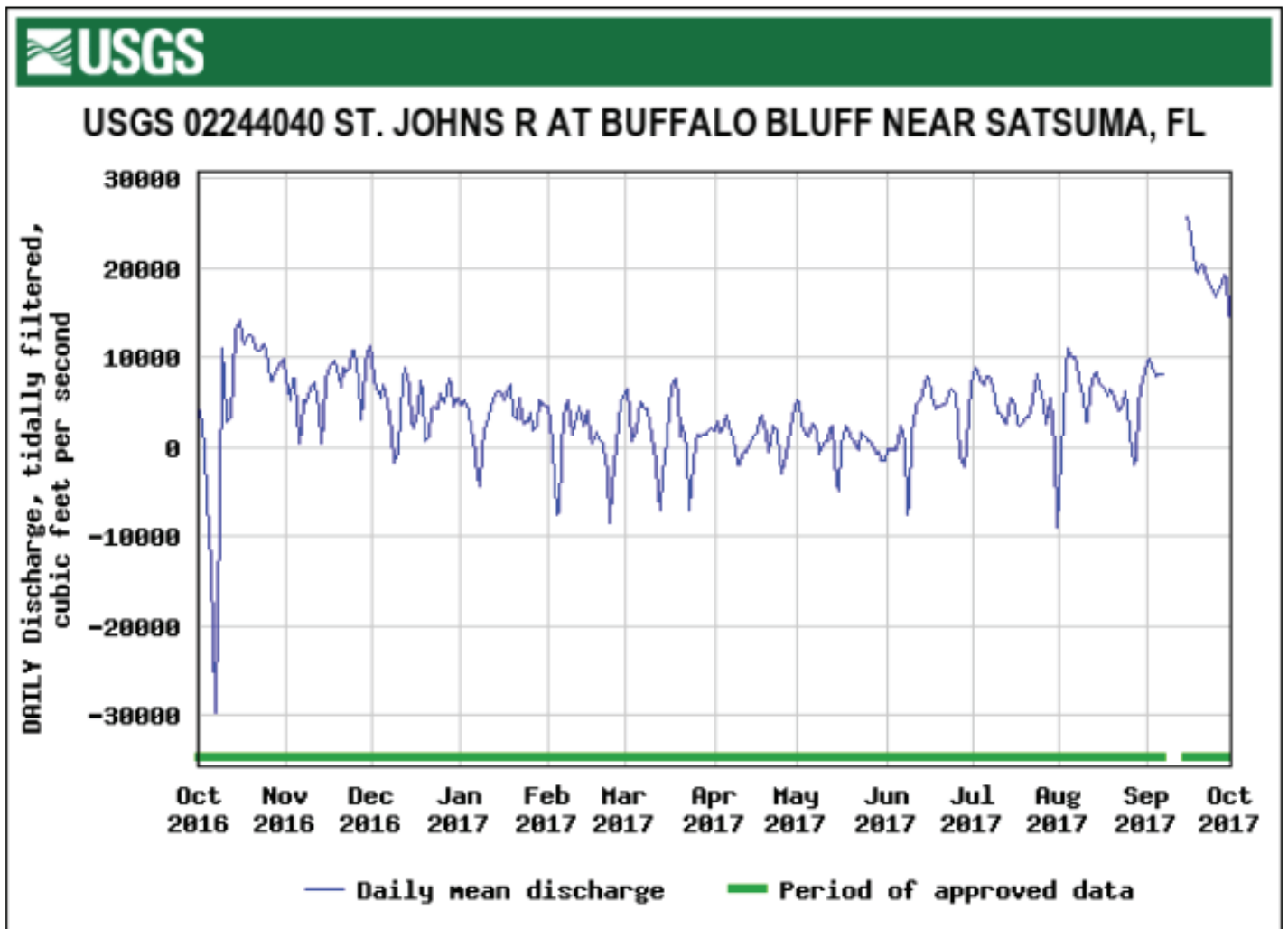

Figure 9. Daily mean tidally filtered discharge for St. Johns River at Buffalo Bluff near Satsuma, Florida.

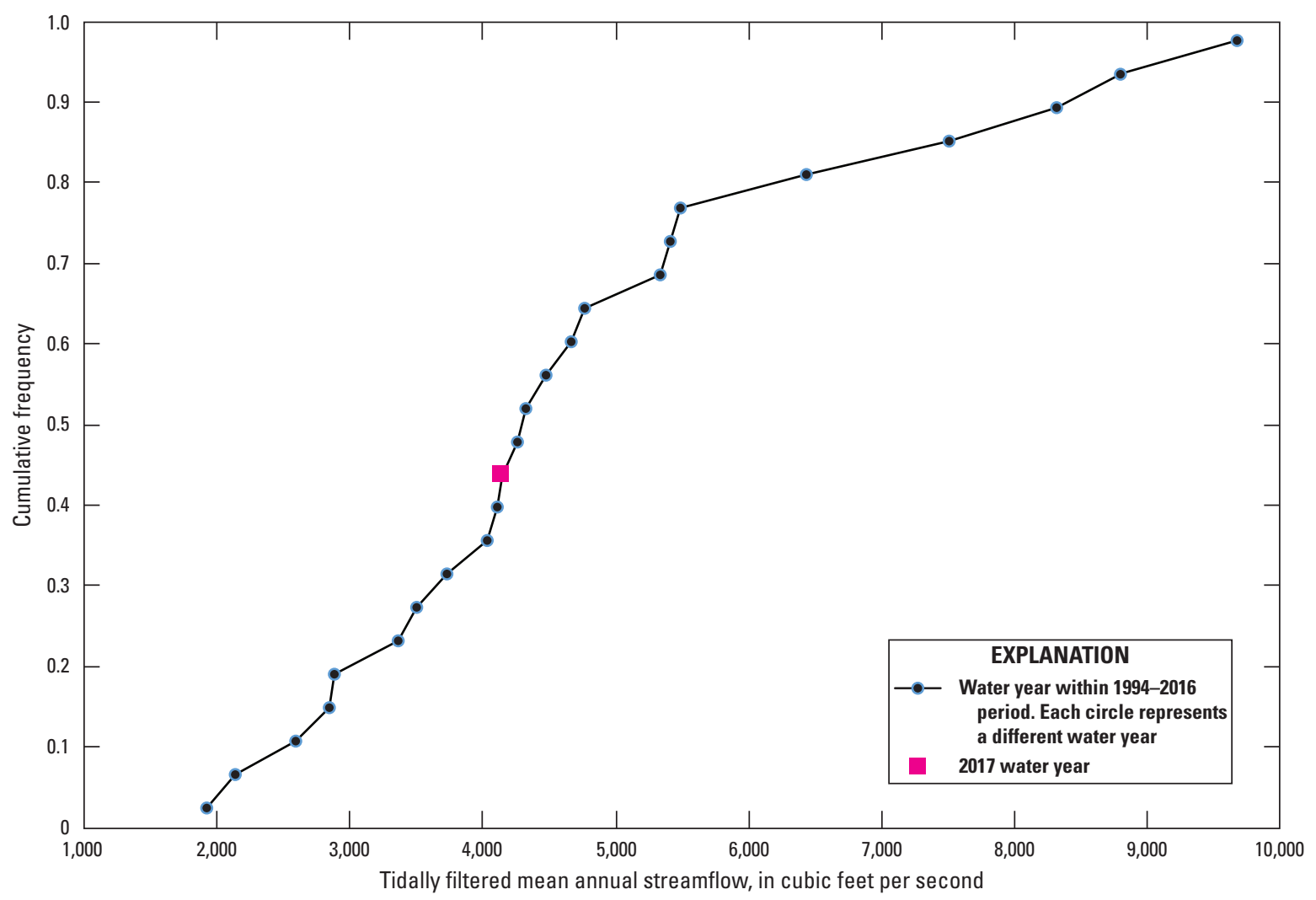

Figure 10. Annual mean tidally filtered streamflow data for St. Johns River at Buffalo Bluff near Satsuma, Florida. 
St. Johns River at Dancy Point near Spuds, FloridaSalinity on the St. Johns River at Dancy Point ranged from 0.1 to 0.6 parts per thousand (ppt) during the 2017 water year, with a median and mean of $0.4 \mathrm{ppt}$ (fig. 11). The salinity data show the effects of increased freshwater flows caused by summertime rainfall, Hurricane Matthew, and Hurricane Irma, even at these low salinity values. No water-quality parameters were monitored for 7 days in October because of equipment damage caused by Hurricane Matthew.

St. Johns River Below Shands Bridge near Green Cove Springs, Florida - Salinity on the St. Johns River below Shands Bridge ranged from 0.2 to $5.2 \mathrm{ppt}$ during the period from June to September 2017 (fig. 12). The monitoring station was installed at a time of relatively high salinity in the river, which decreased over the summer months.

St. Johns River Buckman Bridge at Jacksonville, Florida-Salinity on the St. Johns River at Buckman Bridge ranged from 0.2 to $18 \mathrm{ppt}$ for the top location during the 2017 water year, with a median of $1.2 \mathrm{ppt}$ and mean of $3.4 \mathrm{ppt}$, and from 0.2 to $24 \mathrm{ppt}$ for the bottom location, with a median of $2.9 \mathrm{ppt}$ and mean of $4.4 \mathrm{ppt}$ (figs. 13 and 14). The monitoring station did not monitor water-quality parameters for 30 days in October and November because of equipment damage caused by Hurricane Matthew, 18 days in May and June because of equipment malfunction (top location only), and 10 days in September because of equipment malfunction caused by Hurricane Irma. Weekly salinity fluctuations are common at this location and are caused by rainfall, tides, and wind.
St. Johns River at Christopher Point Near Jacksonville, Florida-Salinity at Christopher Point ranged from 0.3 to $25 \mathrm{ppt}$ during the 2017 water year, with a median of $4.0 \mathrm{ppt}$ and mean of 5.4 ppt (fig. 15). No data were logged for 14 days in September 2017 because of equipment damage caused by Hurricane Irma. Weekly salinity fluctuations are common at this location and are caused by rainfall, tides, and wind.

St. Johns River Below Marco Lake at Jacksonville, Florida-Salinity at Marco Lake ranged from 0.3 to $32 \mathrm{ppt}$ during the 2017 water year, with a median of $5.9 \mathrm{ppt}$ and mean of 7.5 ppt (fig. 16). As at Christopher Point, weekly salinity fluctuations are common at this location and are caused by rainfall, tides, and wind.

St. Johns River at Jacksonville, Florida-Daily tidally filtered discharge at the St. Johns River at Jacksonville ranged from $-47,700$ to $137,000 \mathrm{ft}^{3} / \mathrm{s}$ during the 2017 water year, with an annual mean of $6,370 \mathrm{ft}^{3} / \mathrm{s}$ (fig. 17). This large range in tidally filtered discharge was caused by Hurricane Matthew in October 2016 and Hurricane Irma in September 2017. Because of equipment malfunction, no discharge was calculated from May to July 2017 and no water-quality parameters were monitored from March to July 2017. Salinity ranged from 0.3 to $33 \mathrm{ppt}$ over this same period, with a median of $5.8 \mathrm{ppt}$ and mean of $7.4 \mathrm{ppt}$ (fig. 18). A comparison of historical annual mean tidally filtered flows indicated that 2017 streamflow is in the 59th percentile; however, this streamflow is higher than the actual average would have been for the water year because of the 3 months of missing data in

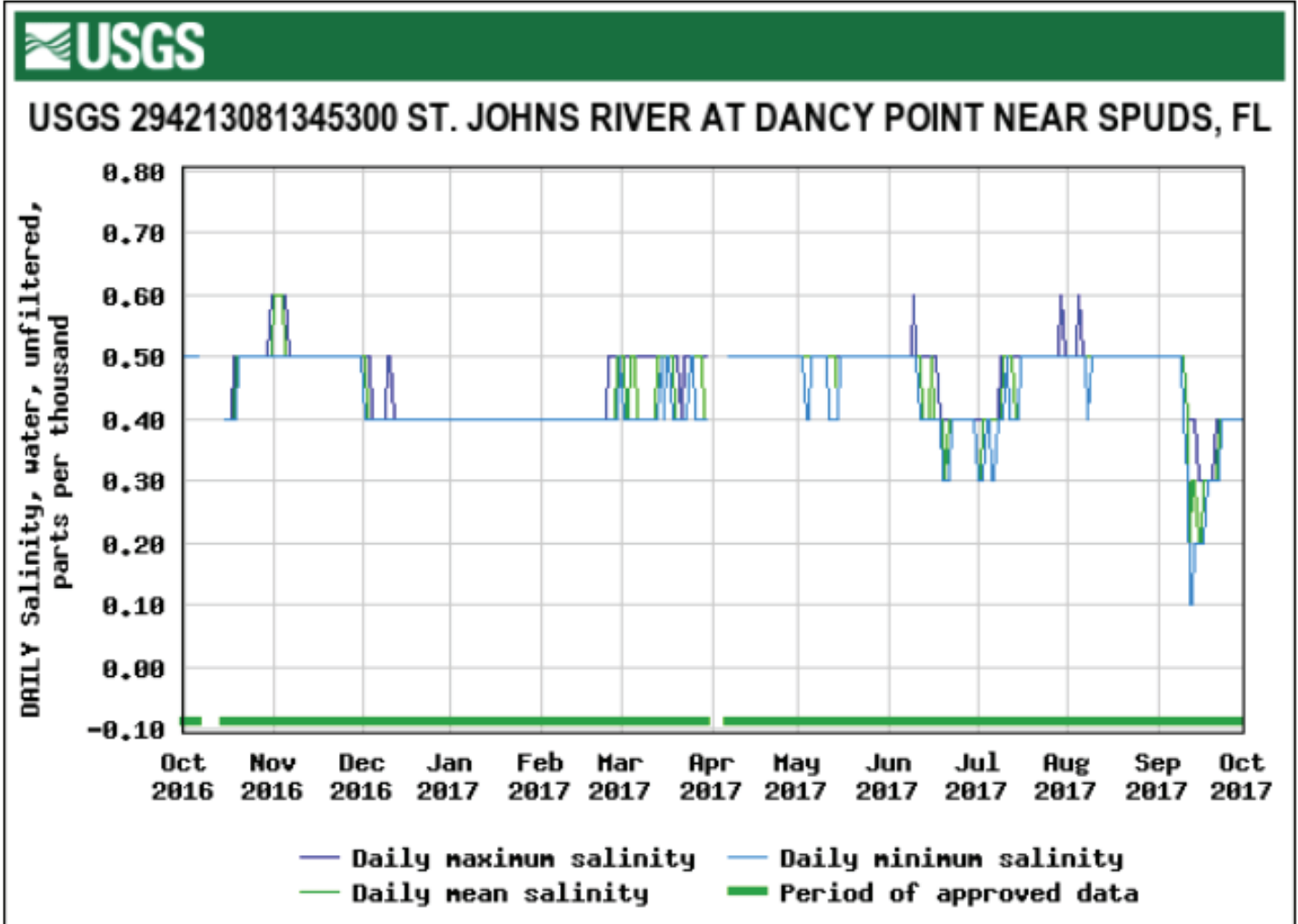

Figure 11. Daily maximum, minimum, and mean salinity for St. Johns River at Dancy Point near Spuds, Florida. 


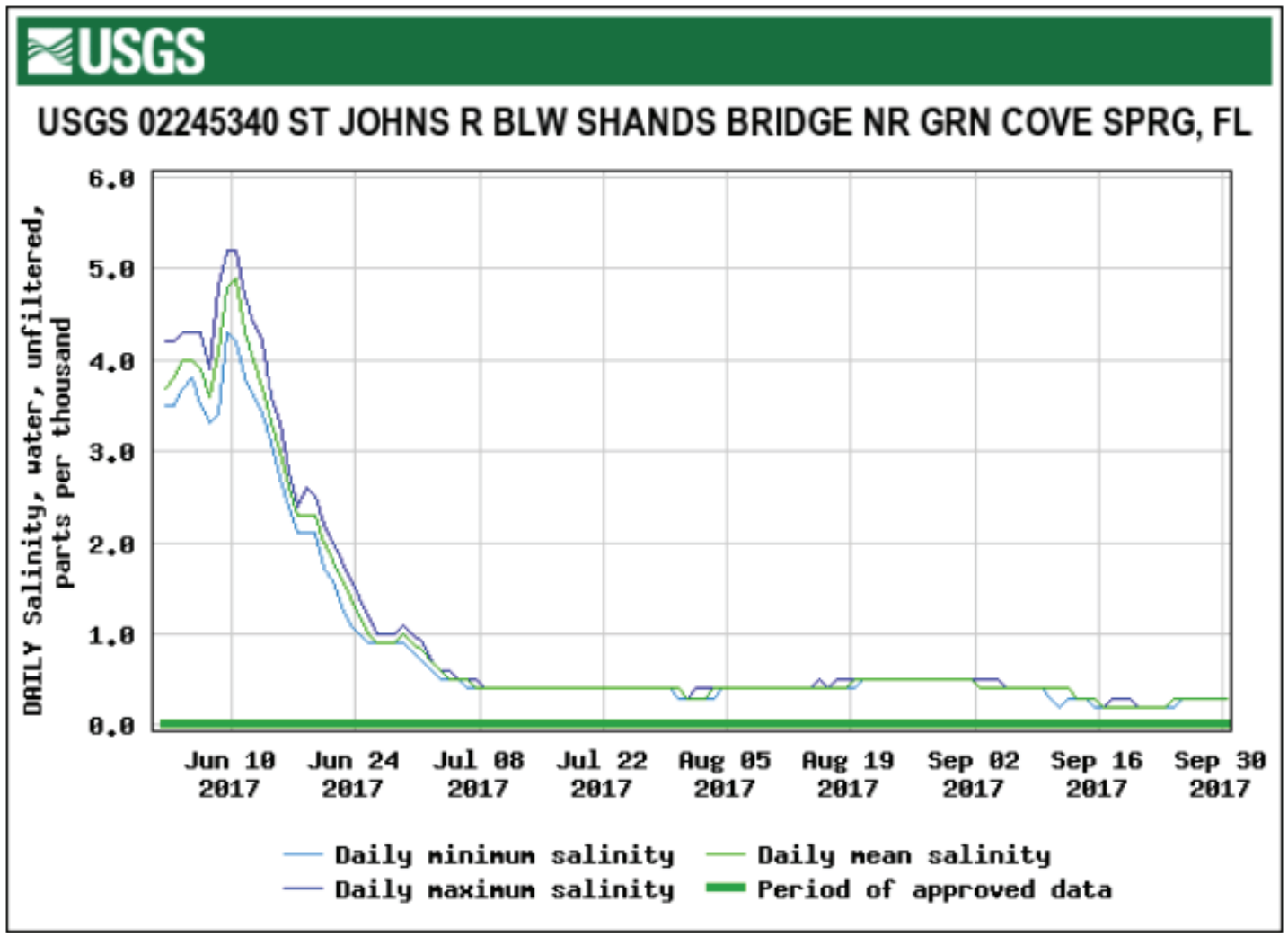

Figure 12. Daily maximum, minimum, and mean salinity for St. Johns River below Shands Bridge near Green Cove Springs, Florida.

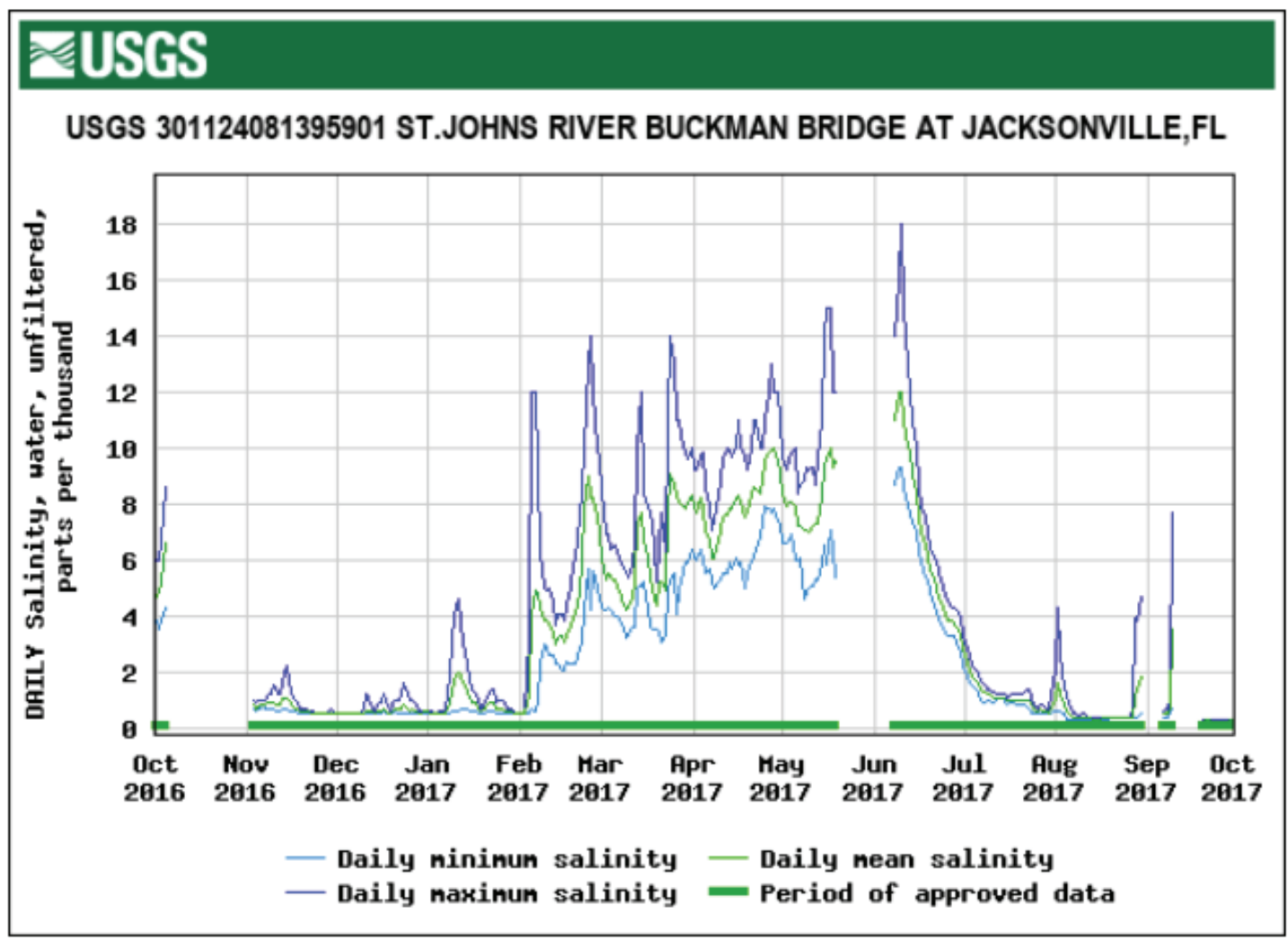

Figure 13. Daily maximum, minimum, and mean salinity for top location of St. Johns River Buckman Bridge at Jacksonville, Florida. 


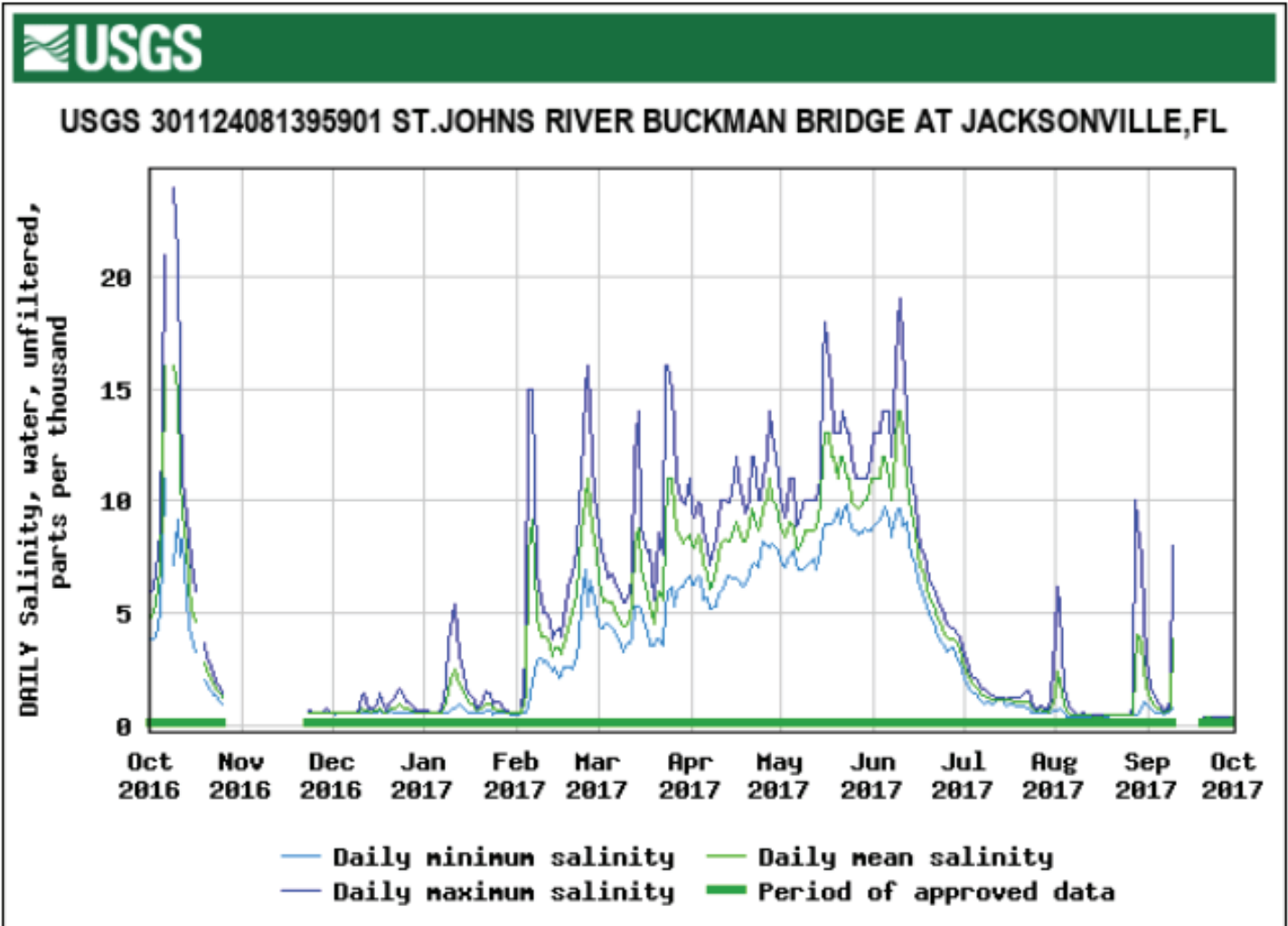

Figure 14. Daily maximum, minimum, and mean salinity for bottom location of St. Johns River Buckman Bridge at Jacksonville, Florida.

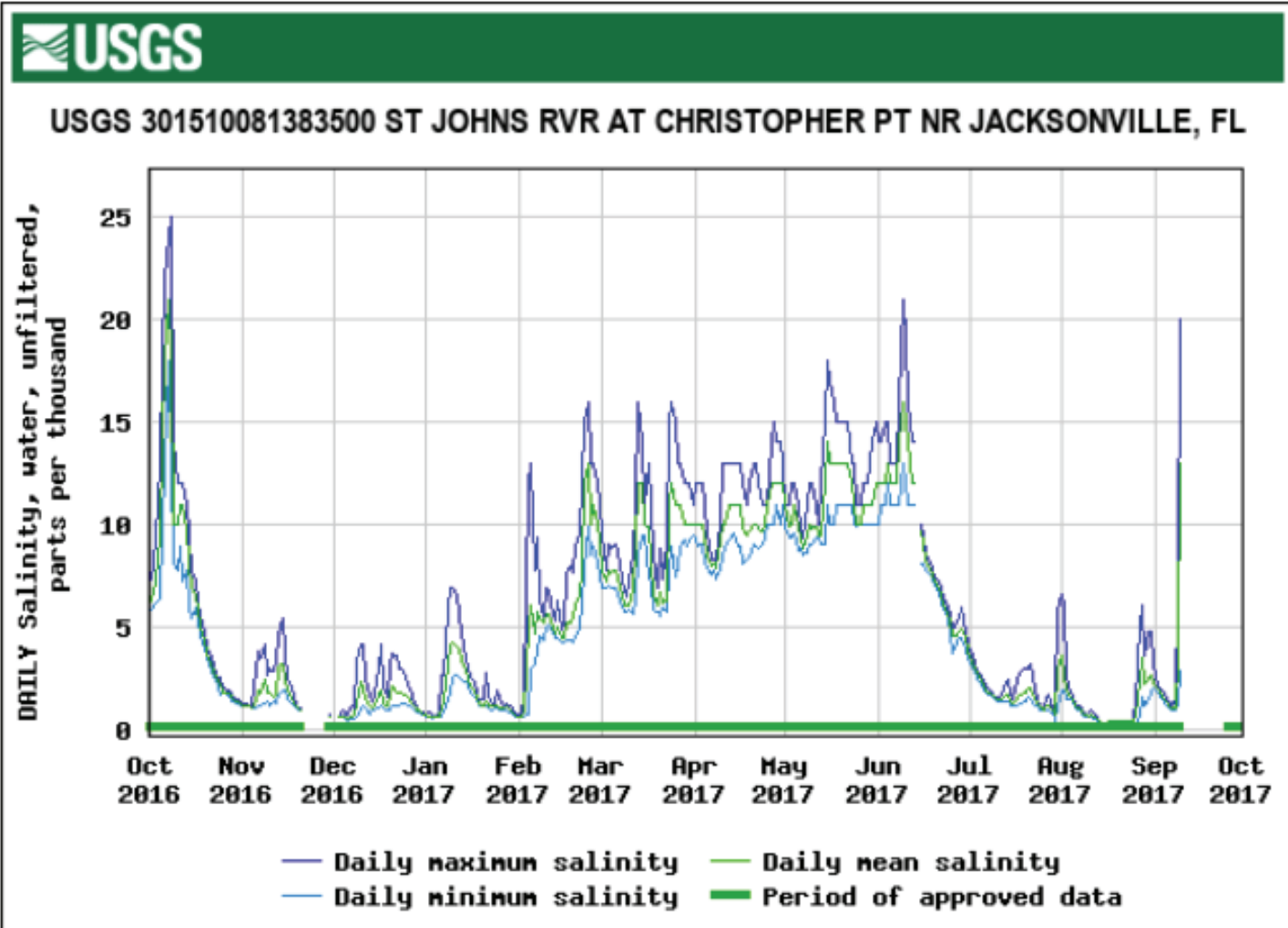

Figure 15. Daily maximum, minimum, and mean salinity for St. Johns River at Christopher Point near Jacksonville, Florida. 


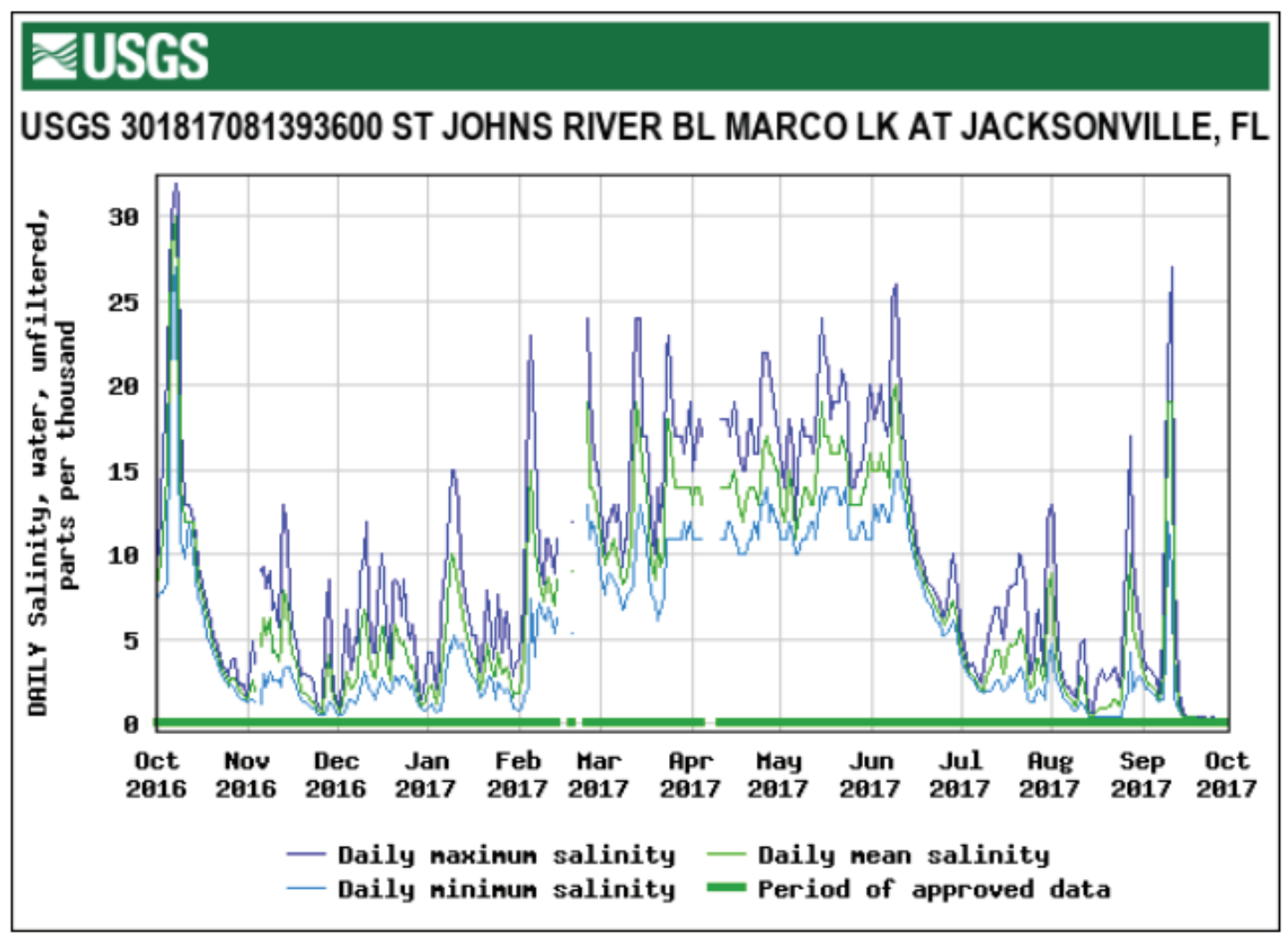

Figure 16. Daily maximum, minimum, and mean salinity for St. Johns River below Marco Lake at Jacksonville, Florida.

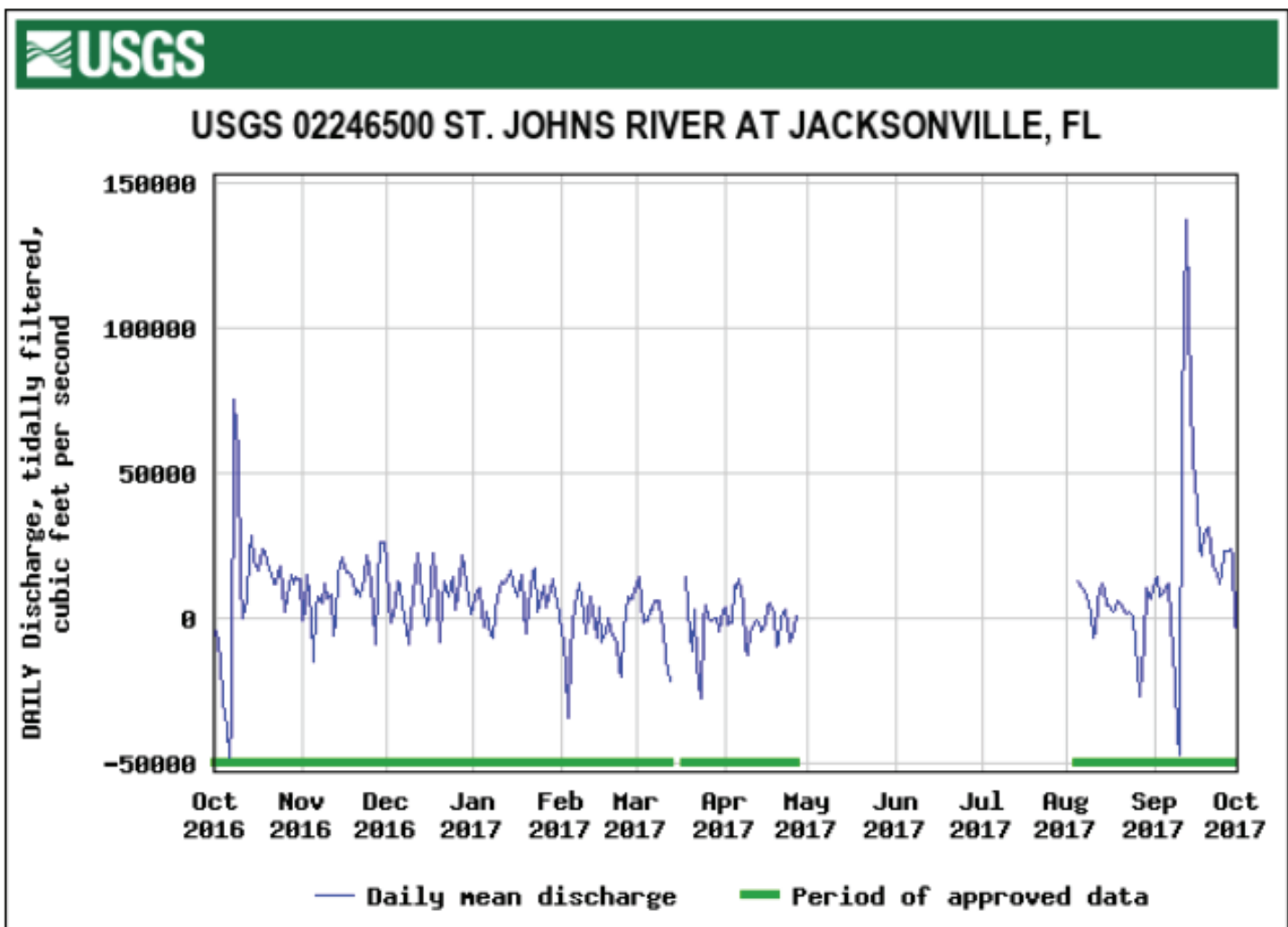

Figure 17. Daily mean tidally filtered discharge for St. Johns River at Jacksonville, Florida. 


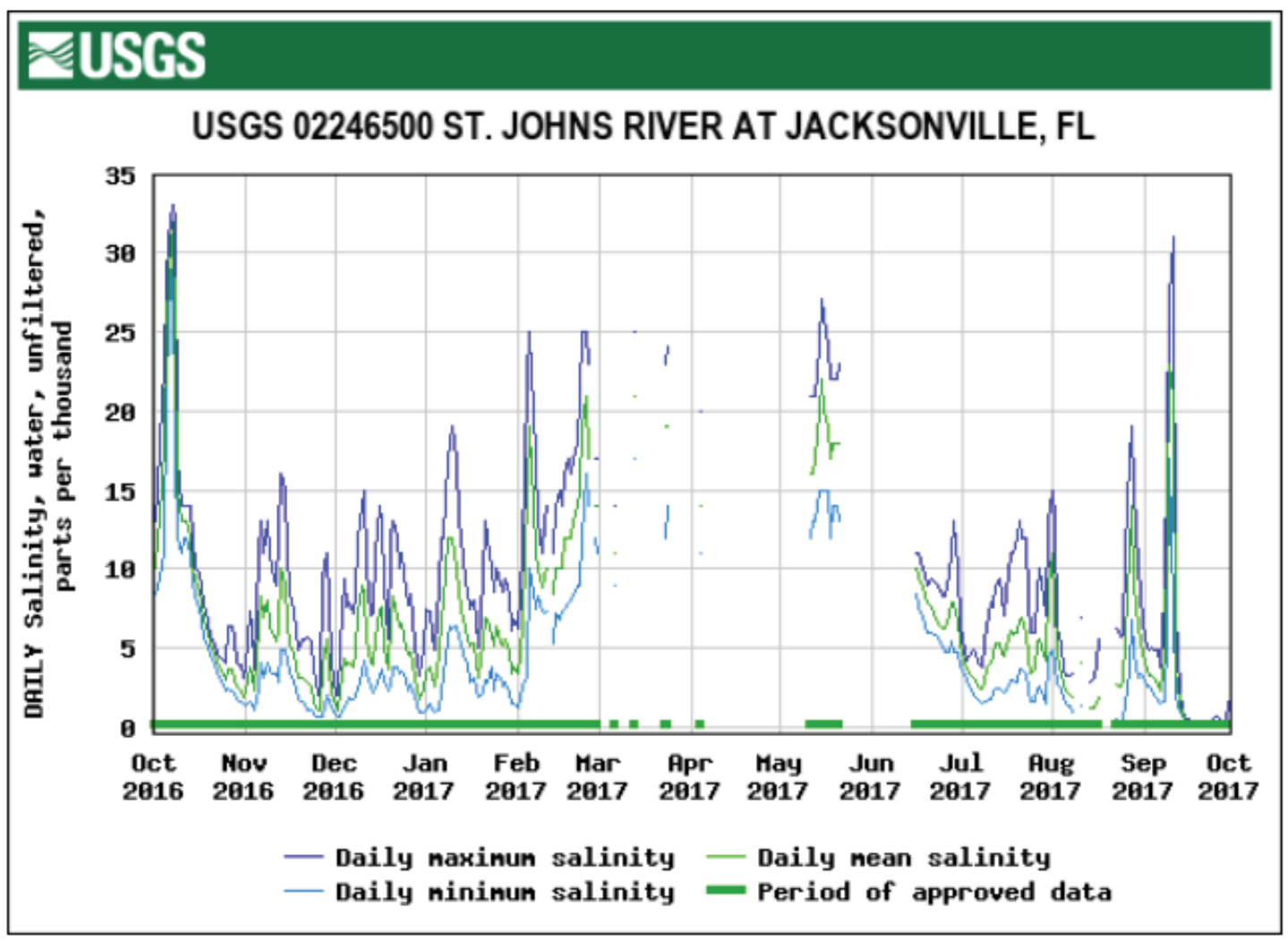

Figure 18. Daily maximum, minimum, and mean salinity for St. Johns River at Jacksonville, Florida.

summer. Because of the hurricanes, flows in October 2016 and September 2017 were higher than the summertime flows and affect the calculated annual mean more than they would have otherwise for a complete year of flow. The actual effect of the missing data on the annual mean is unknown, but a mean in the 59th percentile would still characterize the 2017 water year as average for the annual mean. The median tidally filtered flow for the period of record is $5,490 \mathrm{ft}^{3} / \mathrm{s}$ (fig. 19). Annual mean tidally filtered streamflow record was used from 1996 onward because of data collection gaps in the historical record prior to 1996.

St. Johns River Dames Point Bridge at Jacksonville, Florida - Salinity on the St. Johns River at Dames Point Bridge ranged from 0.5 to $36 \mathrm{ppt}$ for the top location during the 2017 water year, with a median of $23 \mathrm{ppt}$ and mean of $22 \mathrm{ppt}$, and from 0.6 to $36 \mathrm{ppt}$ for the bottom location, with a median and mean of 24 ppt (figs. 20 and 21). Salinity during the period was generally lower at the top location relative to the bottom and fluctuated weekly at both locations because of wind, tides, and upstream conditions.

\section{Tributary Sites}

Julington Creek at Old St. Augustine Road Near Bayard, Florida - Daily tidally filtered discharge at Julington Creek ranged from -12.2 to 3,450 (estimated) $\mathrm{ft}^{3} / \mathrm{s}$ during the 2017 water year, with an annual mean of $69.3 \mathrm{ft}^{3} / \mathrm{s}$ (fig. 22). No data were logged for 17 days in September 2017 because of equipment malfunction caused by Hurricane Irma, but the discharge rise and peak were estimated on the basis of trends and nearby comparison stations. Multiple rises in discharge occurred during the period as a result of rainfall, but the tidally filtered flows remained below $100 \mathrm{ft}^{3} / \mathrm{s}$ during most of the period because of the rapid recessions.

Julington Creek at Hood Landing Near Bayard, Florida-Salinity at Julington Creek at Hood Landing ranged from 0.1 to $6.1 \mathrm{ppt}$ during the 2017 water year, with a median of $0.2 \mathrm{ppt}$ and mean of $0.9 \mathrm{ppt}$ (fig. 23). Salinity increased above 0.5 ppt during two extended periods in October 2016 and February-June 2017. Seven days of data were lost in September 2017 because of equipment malfunction caused by Hurricane Irma. Salinity decreased when flow increased through Julington Creek, which is most likely attributed to freshwater from rainfall.

Durbin Creek Near Fruit Cove, Florida - Daily tidally filtered discharge at Durbin Creek ranged from -29.3 to $1,840 \mathrm{ft}^{3} / \mathrm{s}$ during the 2017 water year, with an annual mean of $104 \mathrm{ft}^{3} / \mathrm{s}$ (fig. 24). Salinity ranged from 0.0 to $2 \mathrm{ppt}$ over this period, with a median and mean of $0.1 \mathrm{ppt}$ (fig. 25). Daily tidal fluctuations were observed, even at low salinities.

Ortega River at Kirwin Road Near Jacksonville, Florida - Daily discharge for Ortega River ranged from 4.83 to $3,640 \mathrm{ft}^{3} / \mathrm{s}$ during the 2017 water year, with an annual mean of $85.1 \mathrm{ft}^{3} / \mathrm{s}$ (fig. 26). Discharge exceeded $10 \mathrm{ft}^{3} / \mathrm{s}$ most 


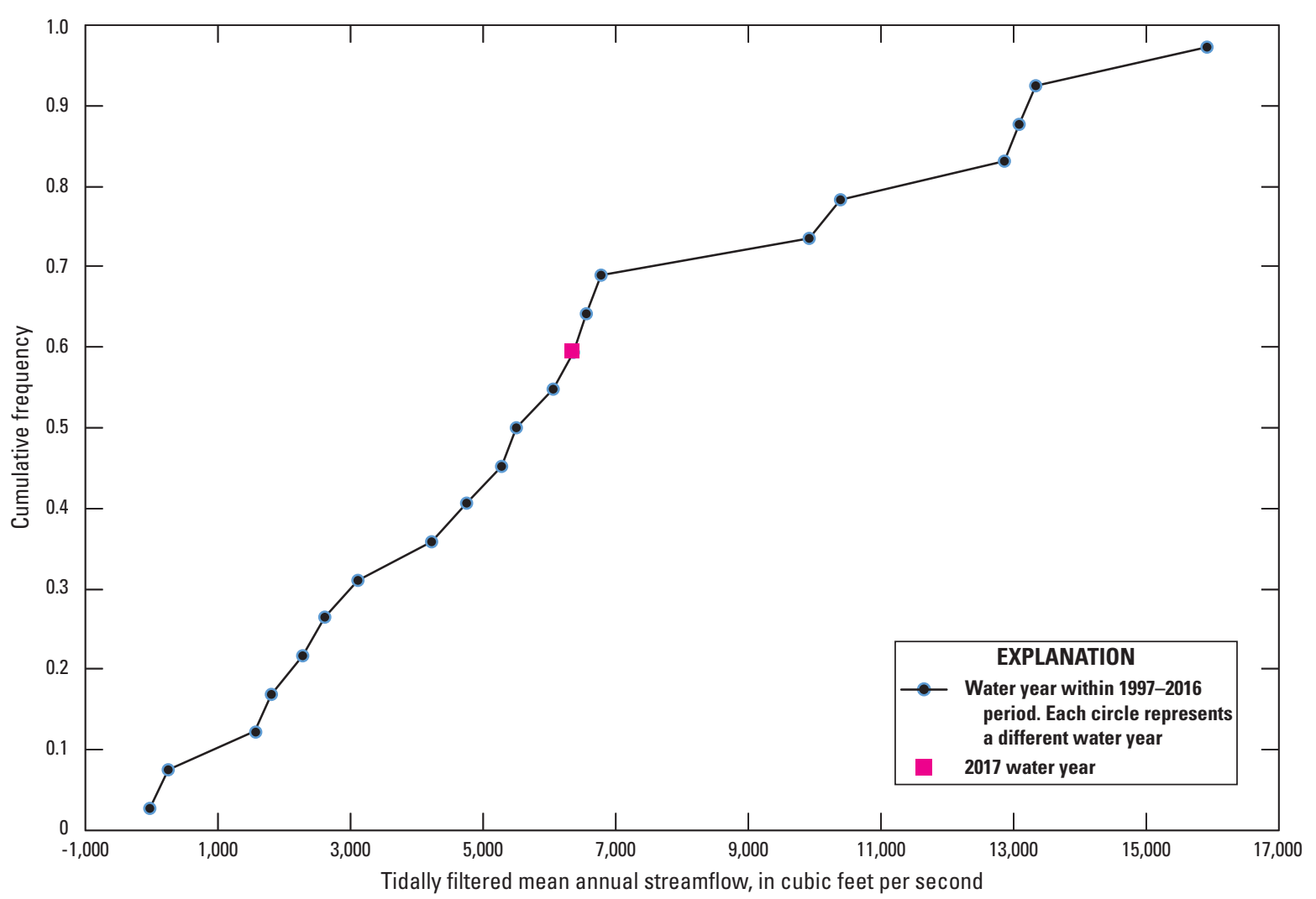

Figure 19. Annual mean tidally filtered streamflow data for St. Johns River at Jacksonville, Florida.

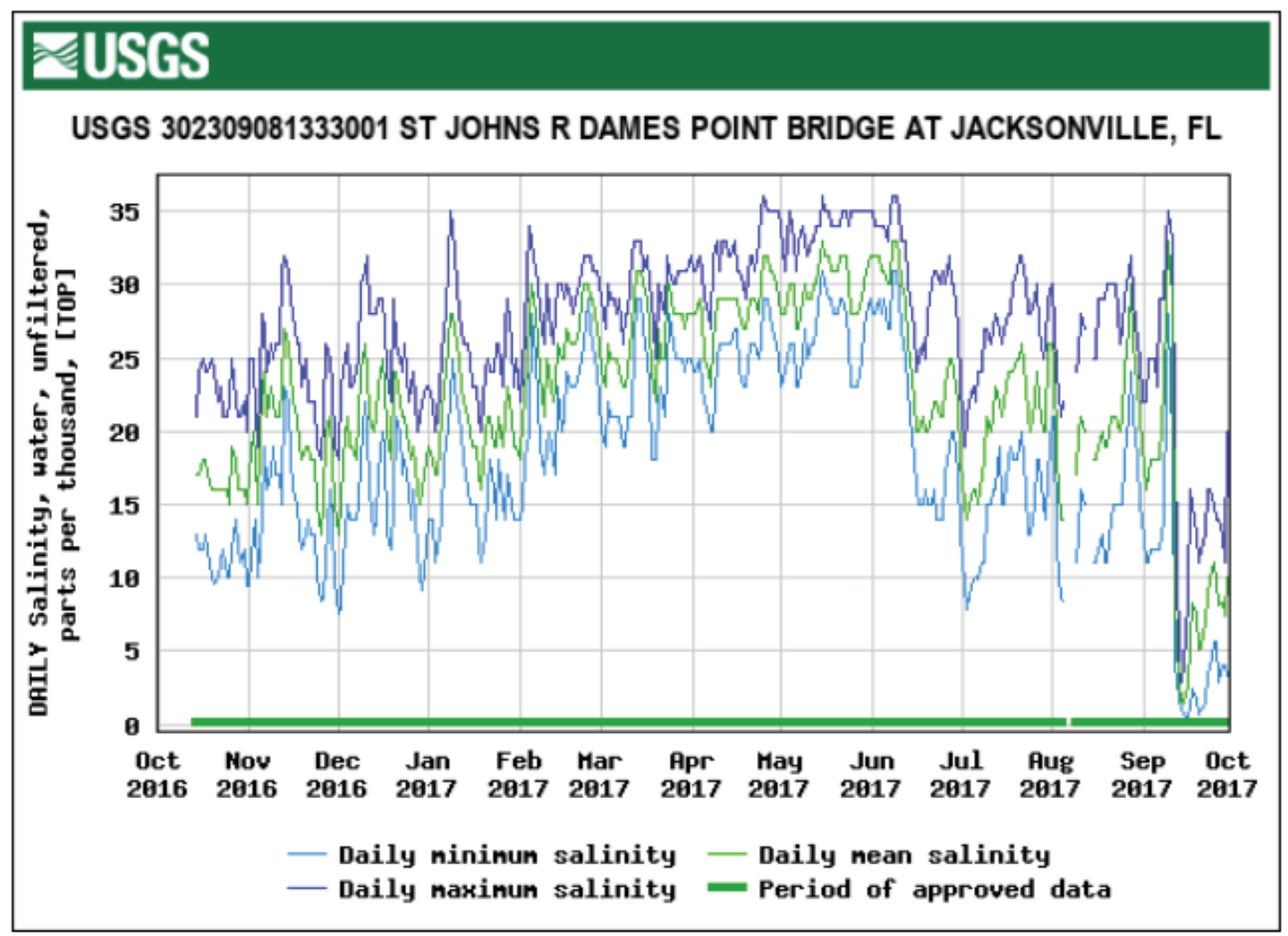

Figure 20. Daily maximum, minimum, and mean salinity for top location of St. Johns River Dames Point Bridge at Jacksonville, Florida. 


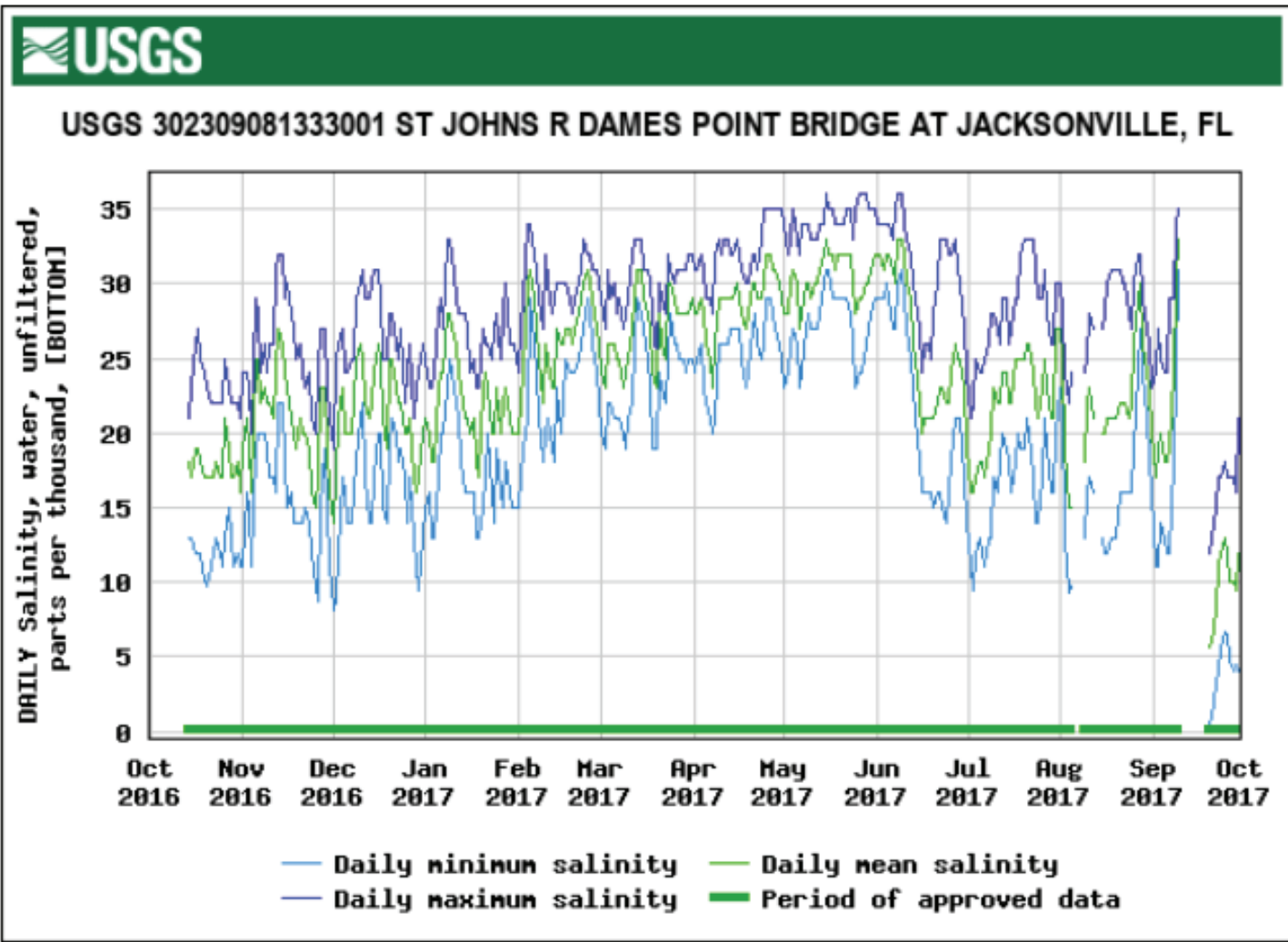

Figure 21. Daily maximum, minimum, and mean salinity for bottom location of St. Johns River Dames Point Bridge at Jacksonville, Florida.

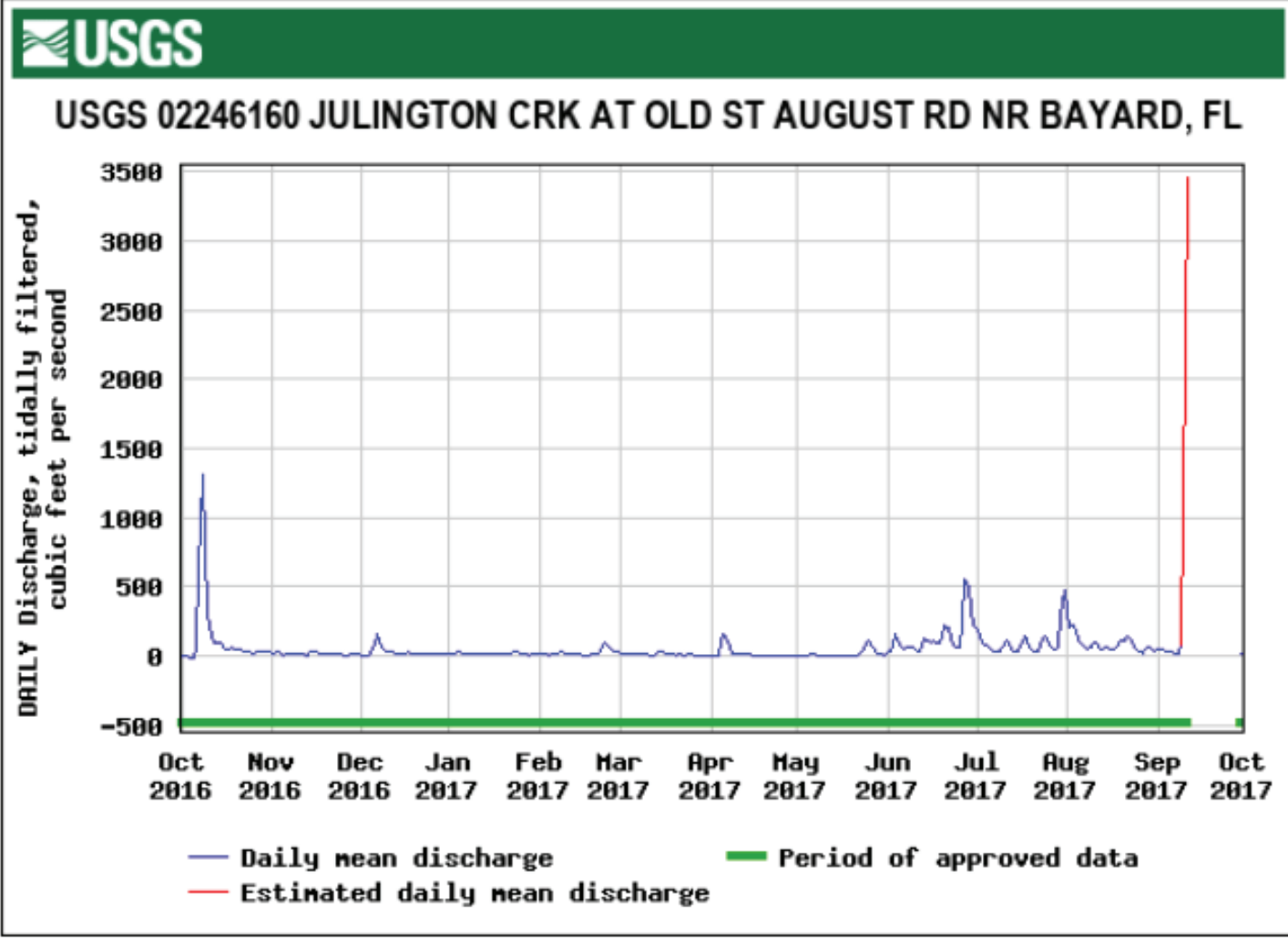

Figure 22. Daily mean tidally filtered discharge for Julington Creek at Old St. Augustine Road near Bayard, Florida. 


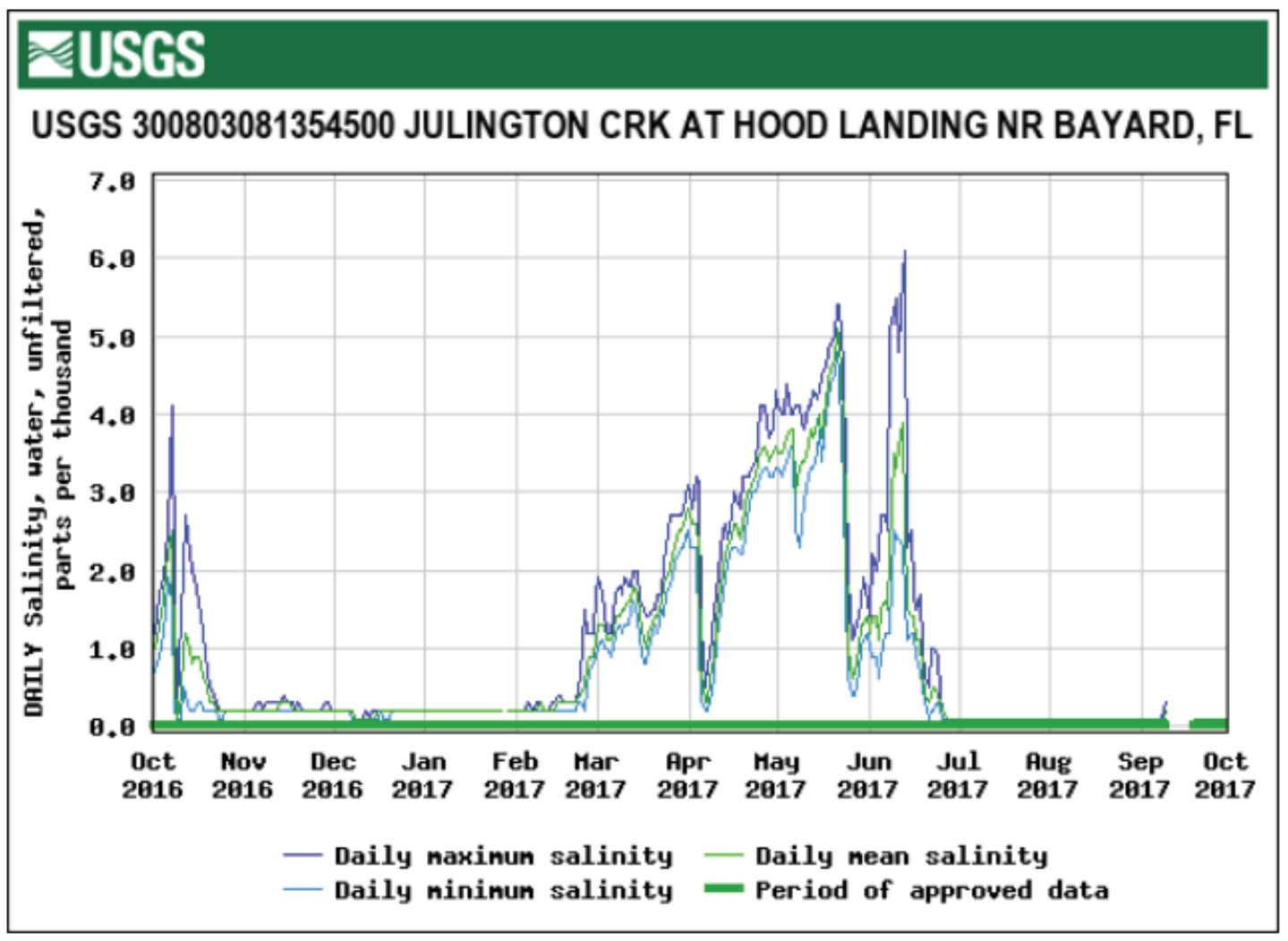

Figure 23. Daily maximum, minimum, and mean salinity for Julington Creek at Hood Landing near Bayard, Florida.

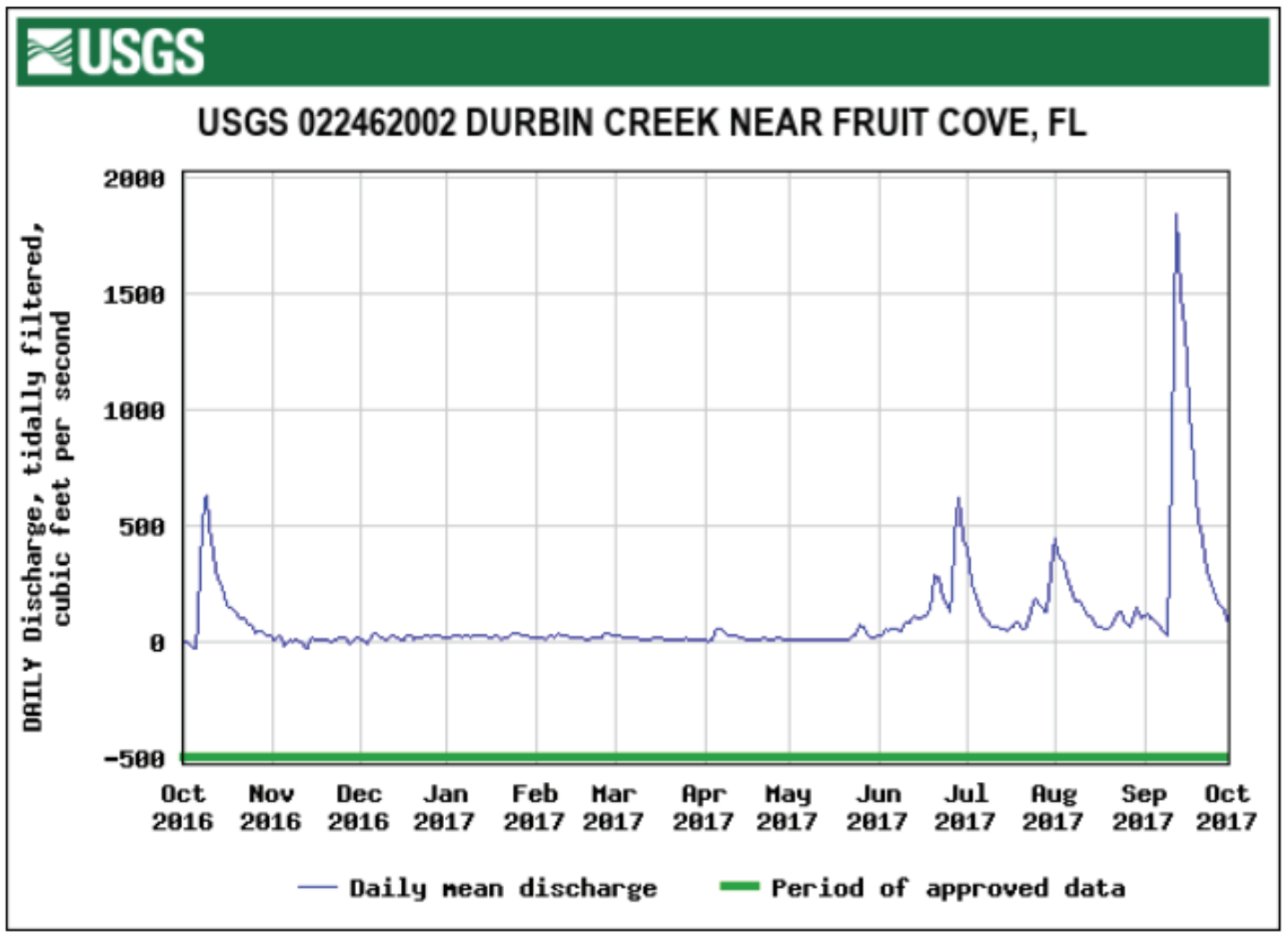

Figure 24. Daily mean tidally filtered discharge for Durbin Creek near Fruit Cove, Florida. 


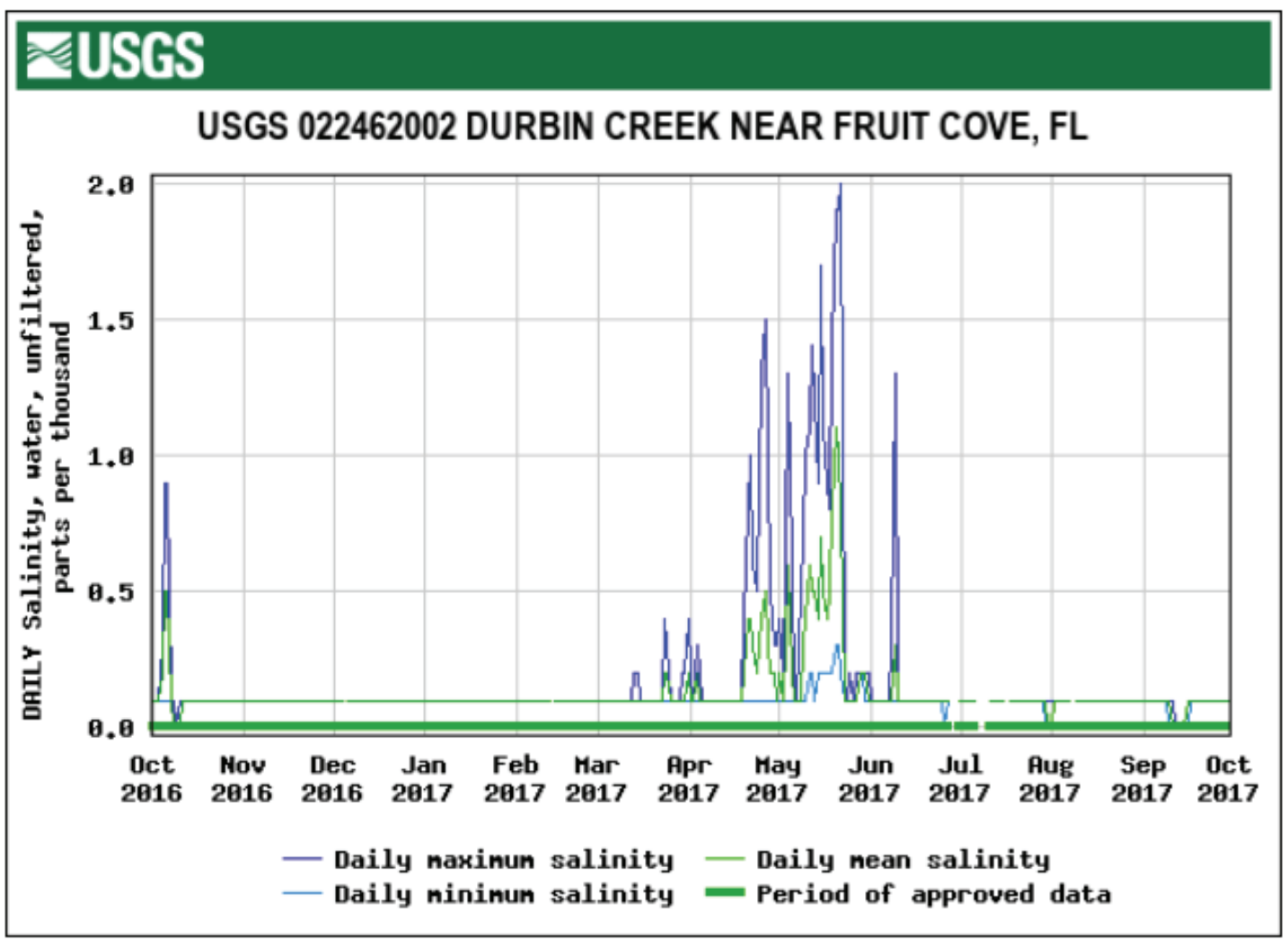

Figure 25. Daily maximum, minimum, and mean salinity for Durbin Creek near Fruit Cove, Florida.

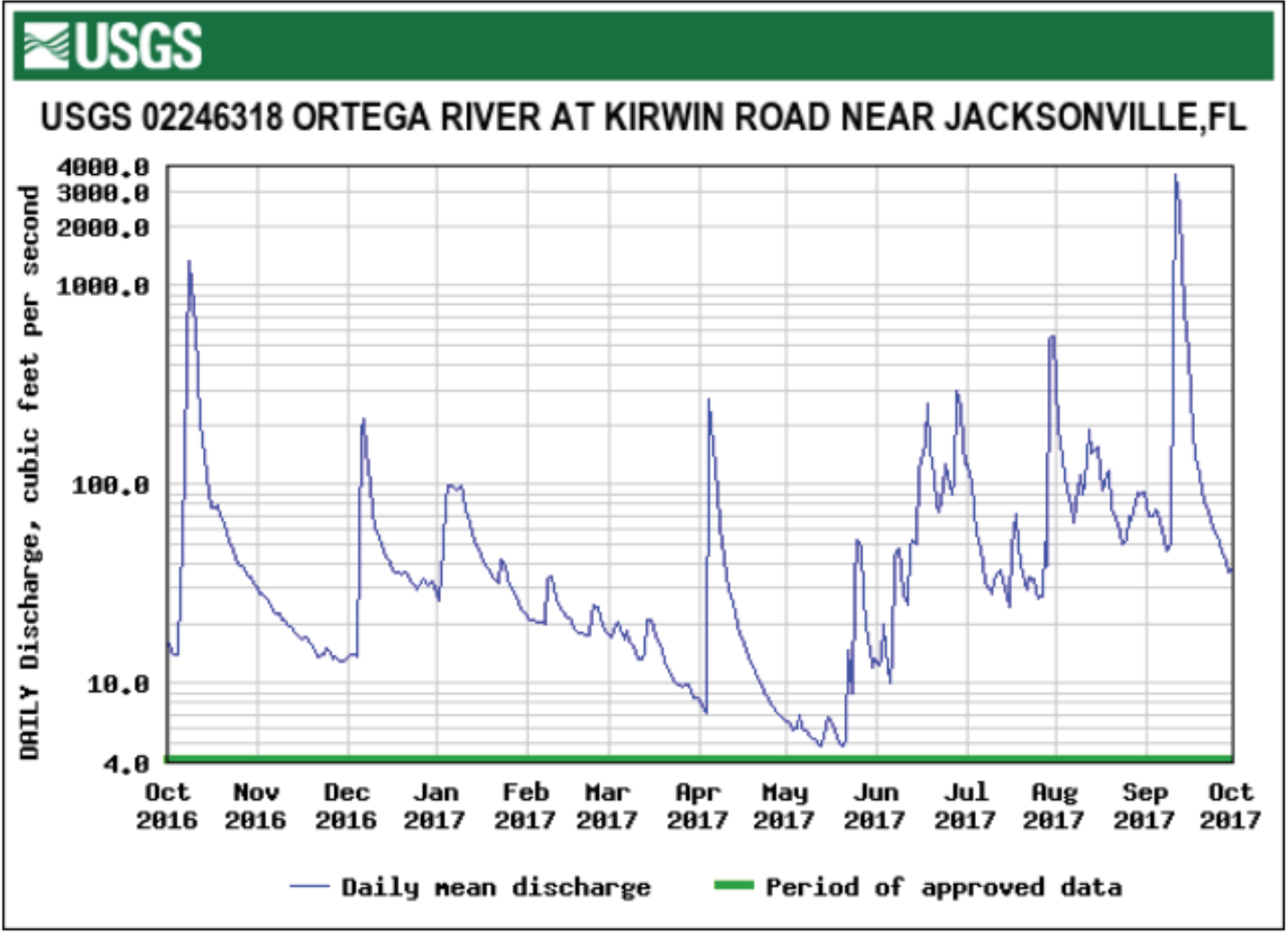

Figure 26. Daily mean discharge for Ortega River at Kirwin Road near Jacksonville, Florida. 
of the year, except during low-flow periods from March to June. The second highest peak for the 10-year period of record occurred during the 2017 water year, and 2017 streamflow ranked in the 84th percentile (fig. 27).

Ortega River Salinity at Jacksonville, Florida - Salinity at Ortega River ranged from 0.0 to $11 \mathrm{ppt}$ during the 2017 water year, with a median of $0.1 \mathrm{ppt}$ and mean of $1.3 \mathrm{ppt}$ (fig. 28). Salinities were highest from February to June during periods of low flow and rainfall.

Cedar River at San Juan Avenue at Jacksonville, FloridaDaily tidally filtered discharge at Cedar River ranged from -37.7 to $937 \mathrm{ft}^{3} / \mathrm{s}$ during the 2017 water year, with an annual mean of $44.4 \mathrm{ft}^{3} / \mathrm{s}$ (fig. 29). No discharge was calculated from August 2017 to mid-September 2017 because of equipment malfunction, so the effects of Hurricane Irma were not documented. Salinity ranged from 0.0 to $23 \mathrm{ppt}$, with a median of $1.0 \mathrm{ppt}$ and mean of $3.2 \mathrm{ppt}$ (fig. 30). Salinity peaked above $10 \mathrm{ppt}$ six times during periods of low flow and rainfall, and during periods of storm surge from Hurricane Matthew (fig. 6).

Pottsburg Creek Near South Jacksonville, FloridaDaily discharge for Pottsburg Creek at Bowden Road ranged from 3.82 to $7,430 \mathrm{ft}^{3} / \mathrm{s}$ during the 2017 water year, with an annual mean of $61.4 \mathrm{ft}^{3} / \mathrm{s}$ (fig. 31). Two rises in discharge exceeding $1,000 \mathrm{ft}^{3} / \mathrm{s}$ occurred during this period as a result of rainfall from Hurricanes Matthew and Irma (fig. 6).

Pottsburg Creek at U.S. 90 Near South Jacksonville, Florida-Daily tidally filtered discharge at Pottsburg Creek at U.S. 90 ranged from -13.1 to $1,350 \mathrm{ft}^{3} / \mathrm{s}$ during the 2017 water year, with an annual mean of $50.8 \mathrm{ft}^{3} / \mathrm{s}$ (fig. 32). Salinity ranged from 0.0 to $12 \mathrm{ppt}$ during the same period, with a median of $0.4 \mathrm{ppt}$ and mean of $1.5 \mathrm{ppt}$ (fig. 33). Peak salinity exceeded 10 ppt during parts of April and May during periods of low flow and rainfall.

Trout River Near Jacksonville, Florida -Daily tidally filtered discharge at Trout River ranged from -244 to $1,500 \mathrm{ft}^{3} / \mathrm{s}$ during the 2017 water year, with an annual mean of $115 \mathrm{ft}^{3} / \mathrm{s}$ (fig. 34). Tidally filtered discharge exceeded $1,000 \mathrm{ft}^{3} / \mathrm{s}$ in October 2016 and August 2017, but 7 days of discharge data were lost because of equipment malfunction caused by Hurricane Irma in September 2017.

Trout River Below U.S. 1 at Dinsmore, Florida - Salinity at Trout River below U.S. 1 ranged from 0.0 to 17 ppt during the 2017 water year, with a median of $0.9 \mathrm{ppt}$ and mean of $3.2 \mathrm{ppt}$ (fig. 35). Daily maximum salinity values peaked above $10 \mathrm{ppt}$ in early October because of storm surge from Hurricane Matthew and remained above 10 ppt from March to May 2017 because of low flow and rainfall.

Broward River Below Biscayne Boulevard Near Jacksonville, Florida - Daily tidally filtered discharge at Broward River ranged from -27.5 to $964 \mathrm{ft}^{3} / \mathrm{s}$ during the 2017 water year, with an annual mean of $43.9 \mathrm{ft}^{3} / \mathrm{s}$. Discharge was relatively consistent during the period, with six peaks in daily tidally filtered discharge exceeding $200 \mathrm{ft}^{3} / \mathrm{s}$ (fig. 36). Salinity ranged from 0.0 to $17 \mathrm{ppt}$ during the 2017 water year, with a median of $0.5 \mathrm{ppt}$ and mean of $2.1 \mathrm{ppt}$ (fig. 37). Salinity remained below 5 ppt from June through September because of overall above average rainfall for those months in Duval County (fig. 6).

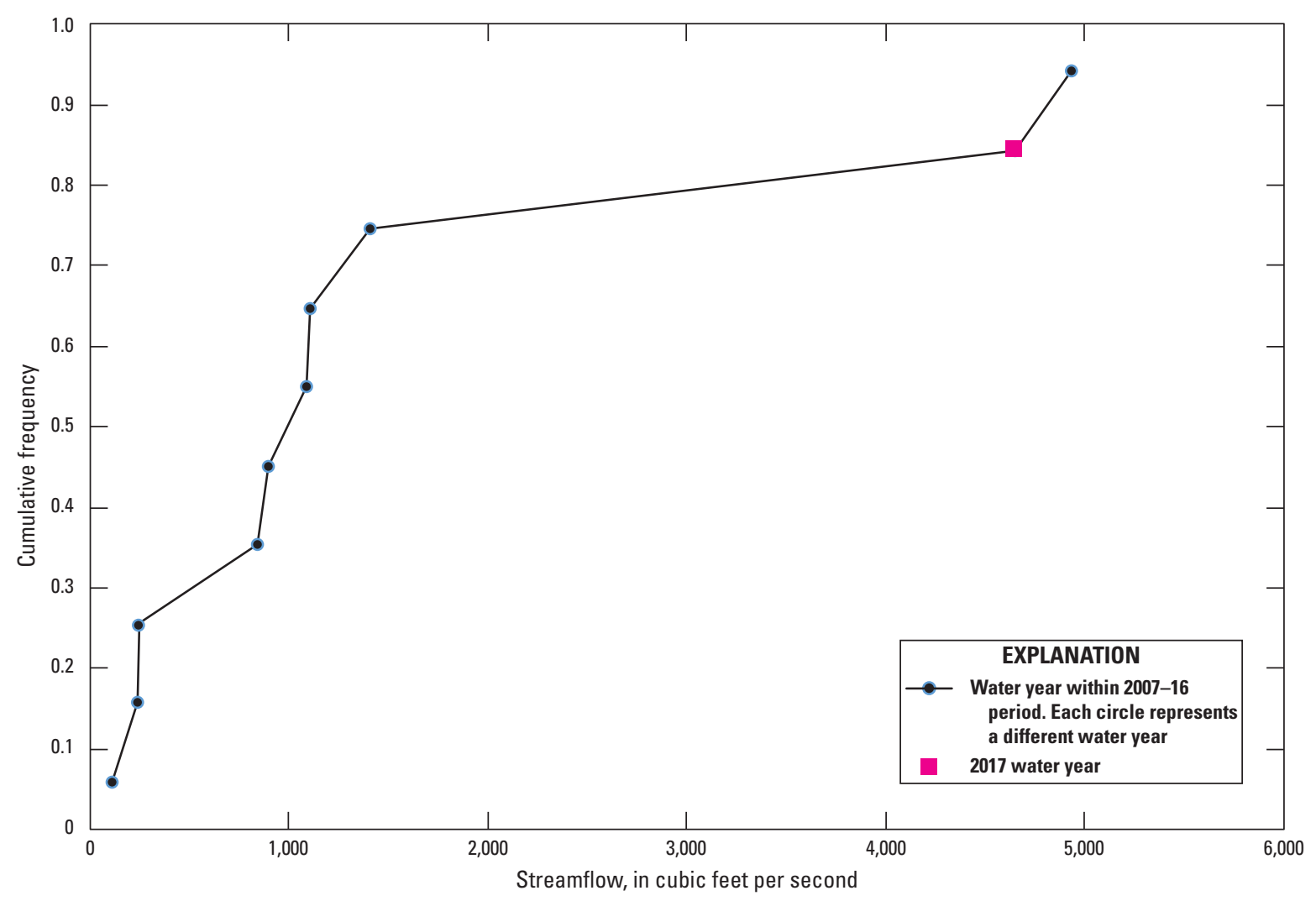

Figure 27. Streamflow at Ortega River at Kirwin Road near Jacksonville, Florida. 


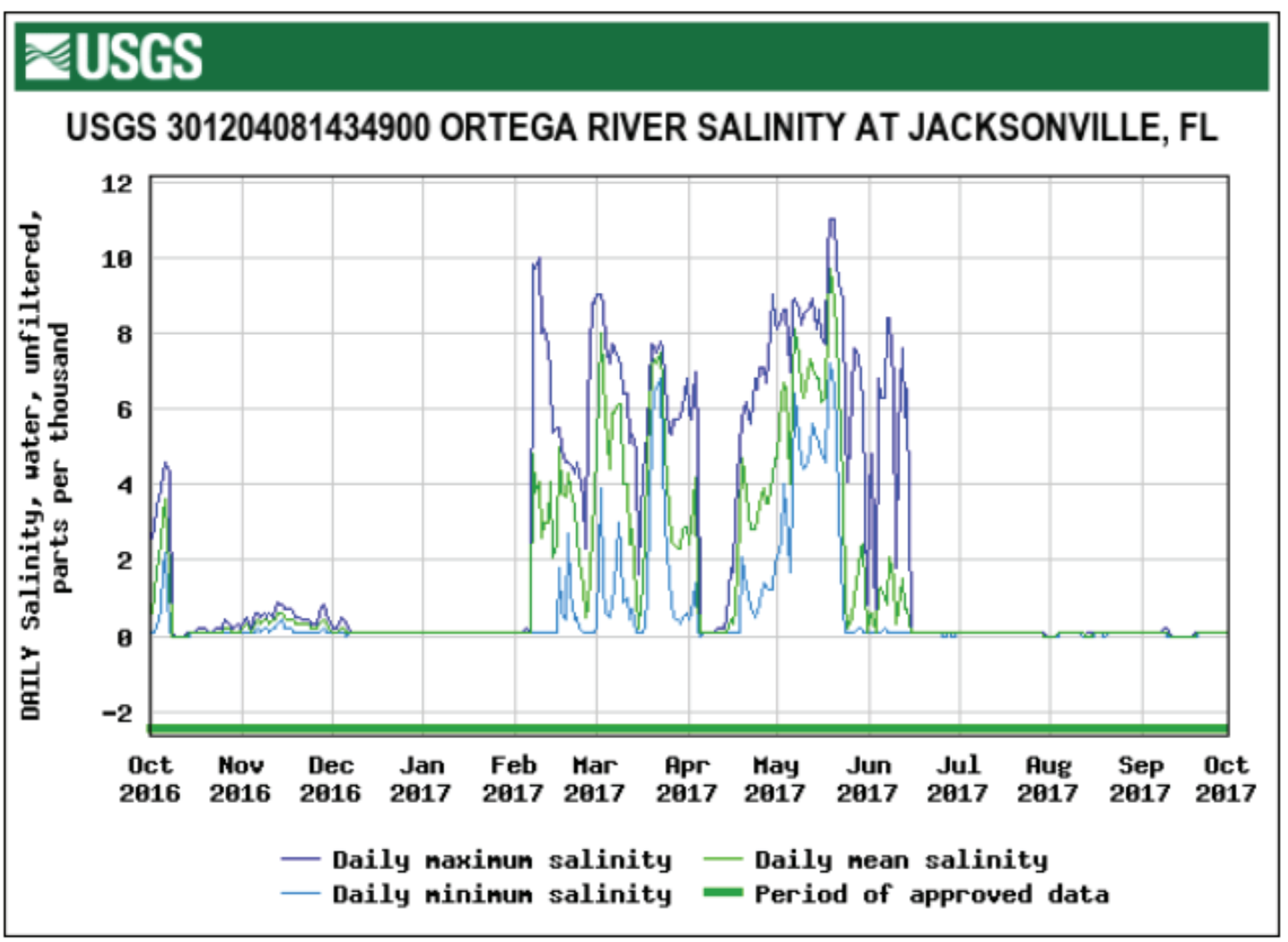

Figure 28. Daily maximum, minimum, and mean salinity for Ortega River salinity at Jacksonville, Florida.

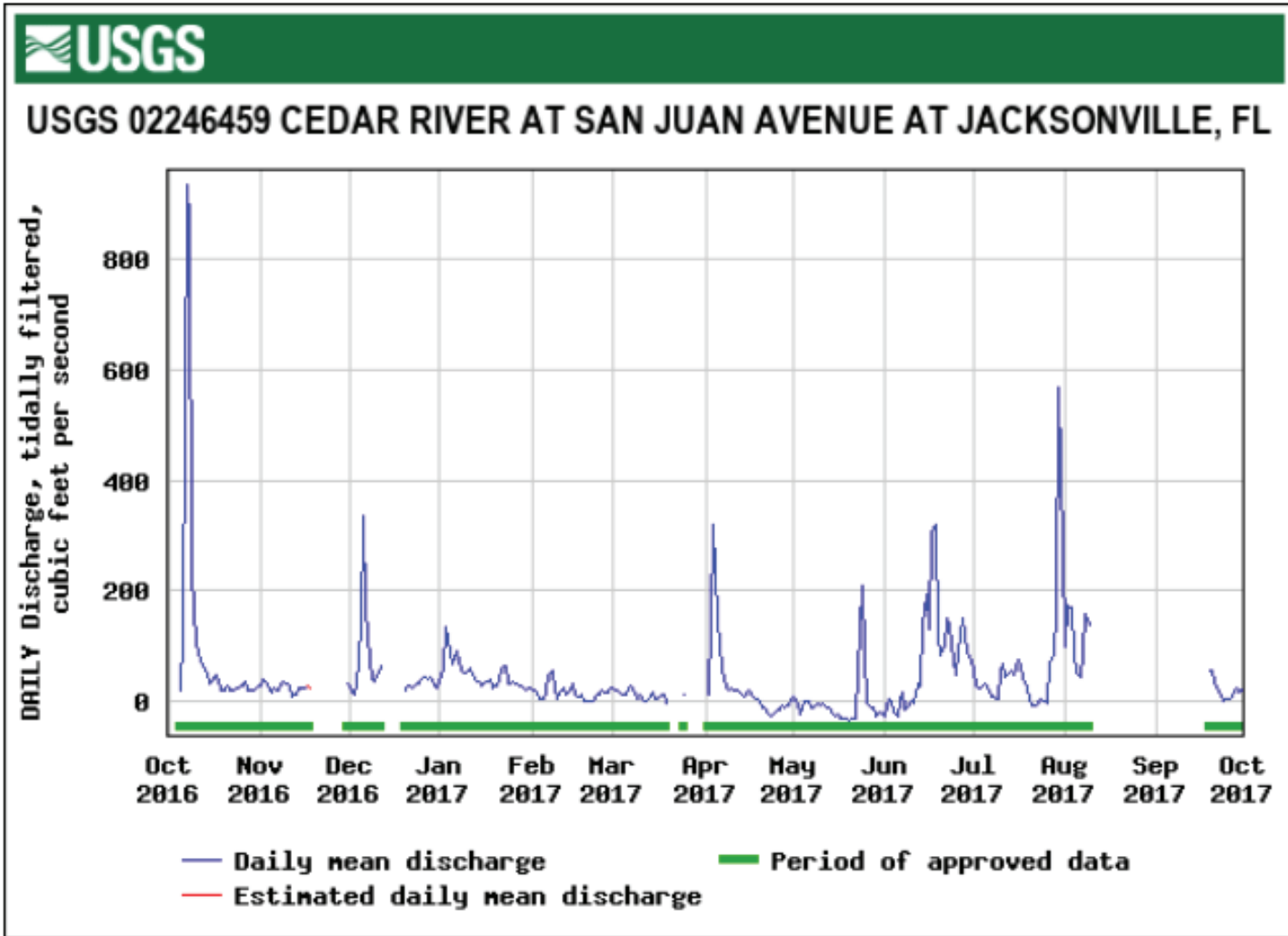

Figure 29. Daily mean tidally filtered discharge for Cedar River at San Juan Avenue at Jacksonville, Florida. 


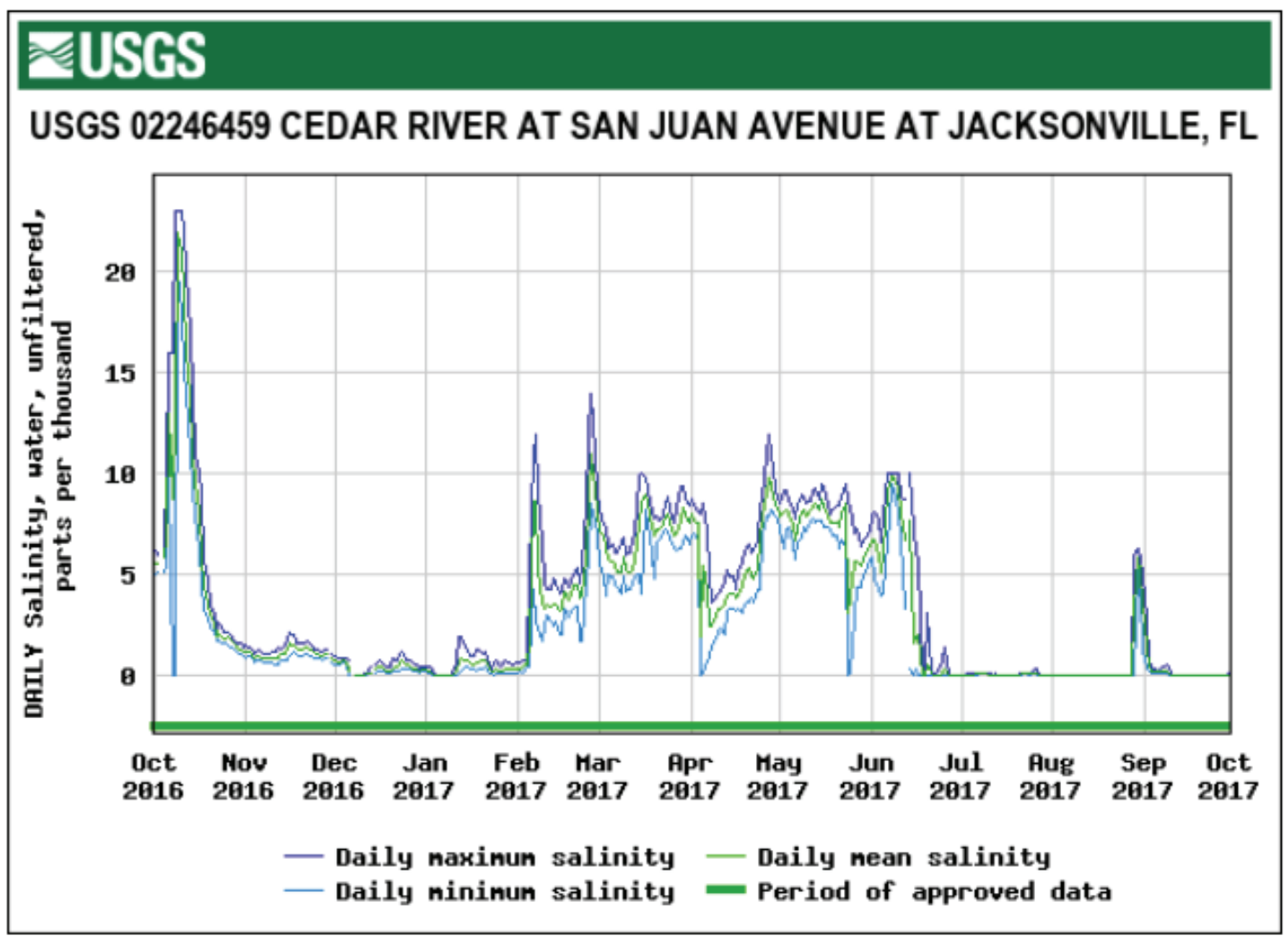

Figure 30. Daily maximum, minimum, and mean salinity for Cedar River at San Juan Avenue at Jacksonville, Florida.

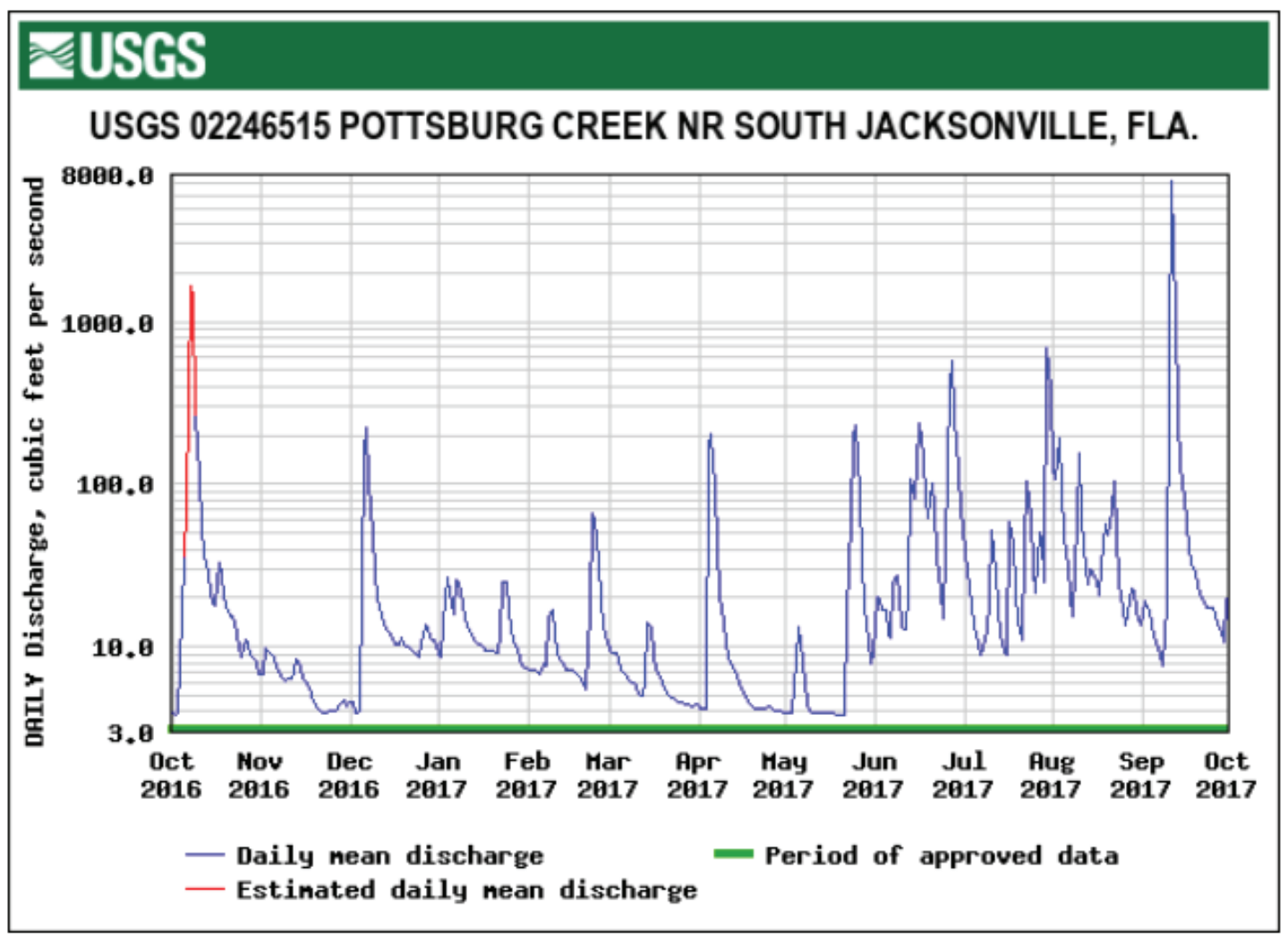

Figure 31. Daily mean discharge for Pottsburg Creek near South Jacksonville, Florida. 


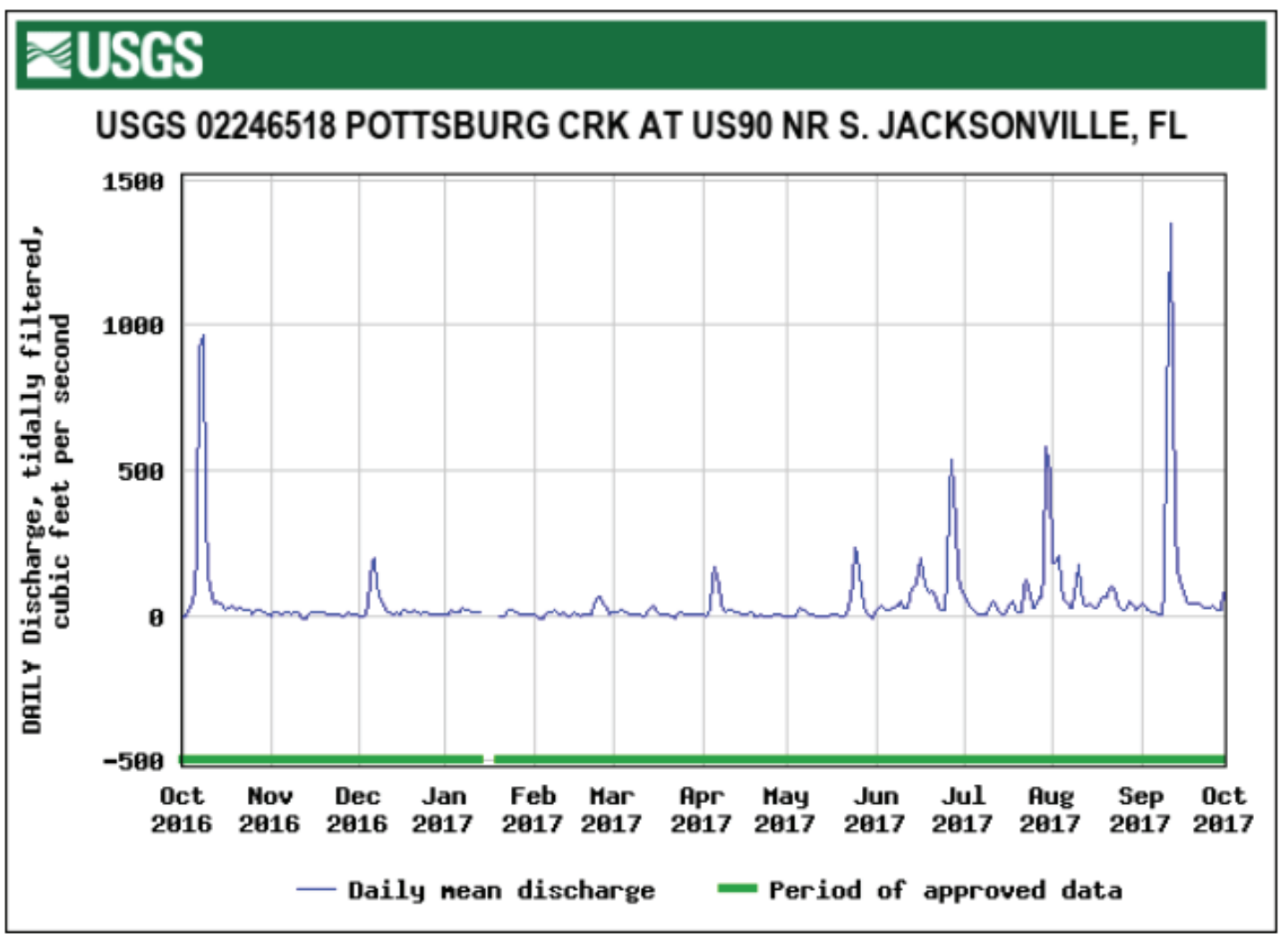

Figure 32. Daily mean tidally filtered discharge for Pottsburg Creek at U.S. 90 near South Jacksonville, Florida.

\section{FUSGS}

USGS 02246518 POTTSBURG CRK AT US90 NR S. JACKSONVILLE, FL

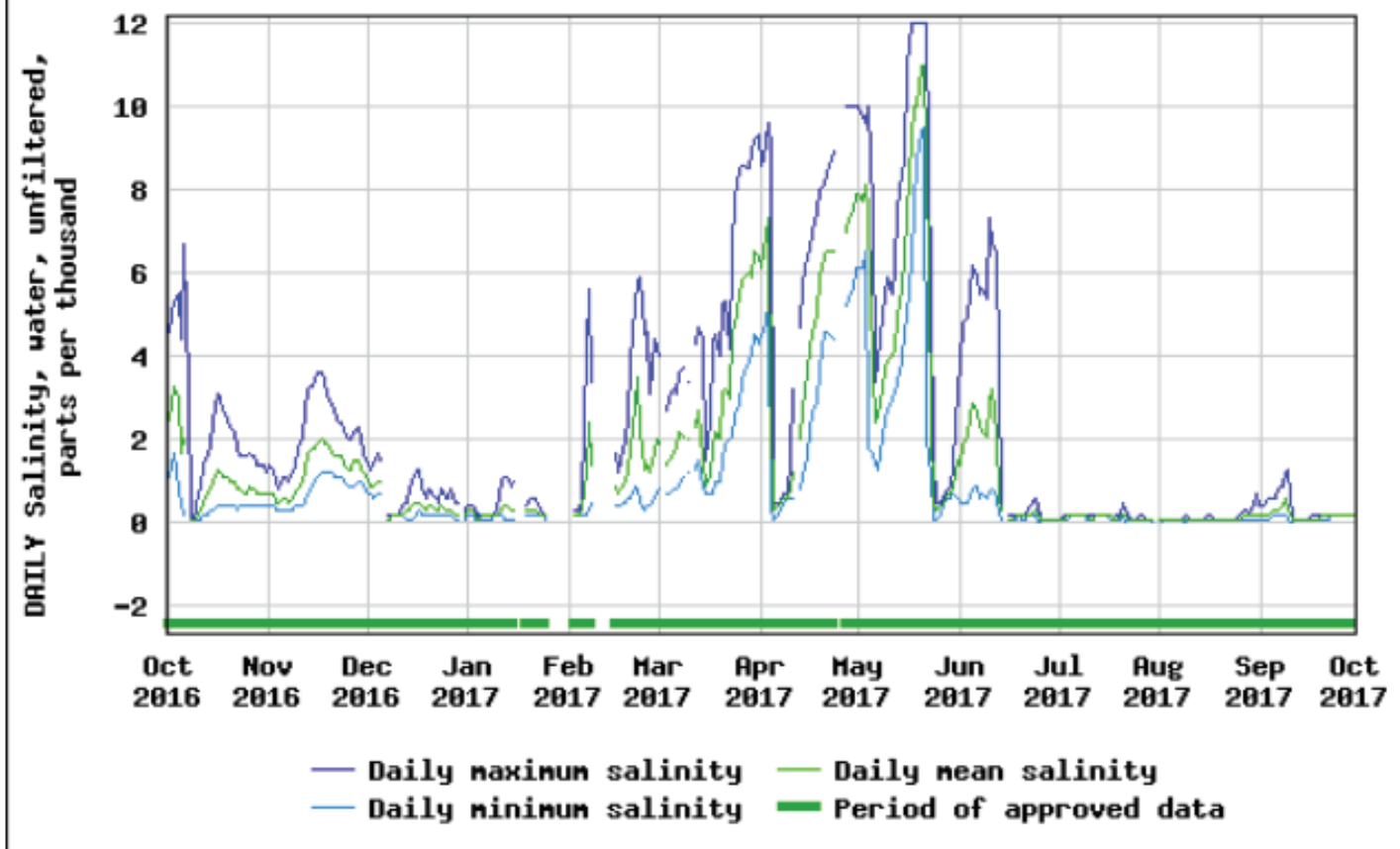

Figure 33. Daily maximum, minimum, and mean salinity for Pottsburg Creek at U.S. 90 near South Jacksonville, Florida. 


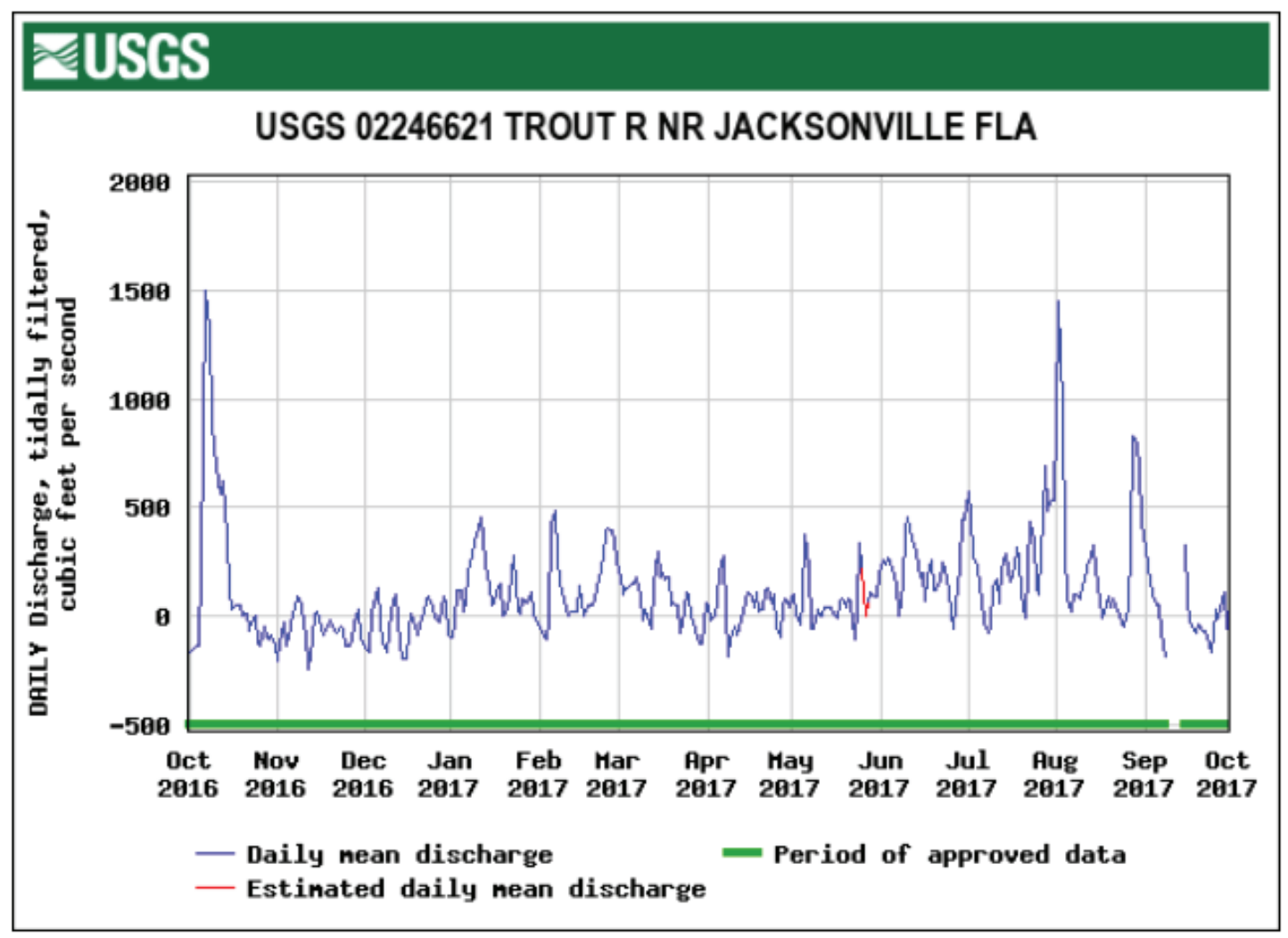

Figure 34. Daily mean tidally filtered discharge for Trout River near Jacksonville, Florida.

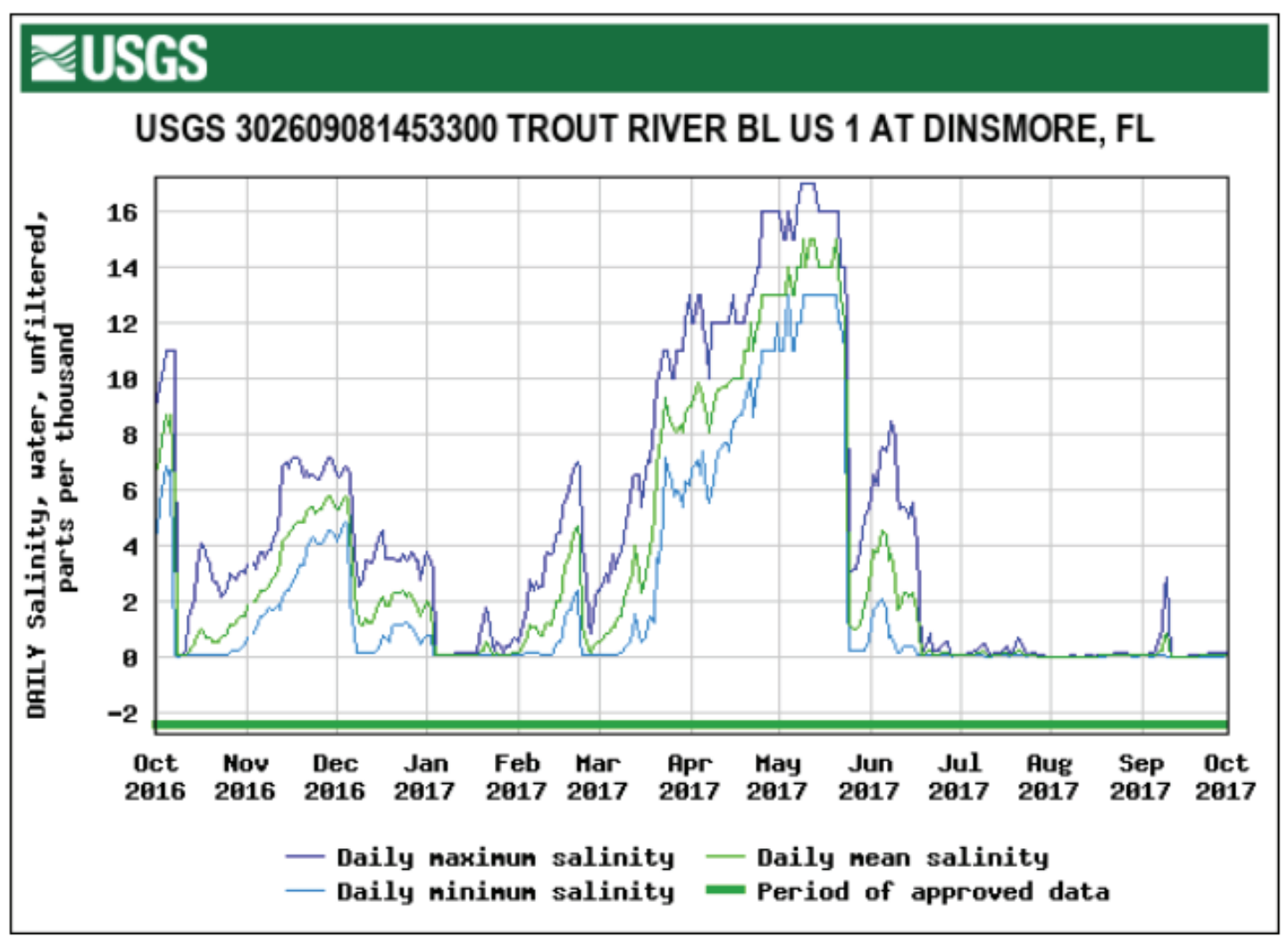

Figure 35. Daily maximum, minimum, and mean salinity for Trout River below U.S. 1 at Dinsmore, Florida. 


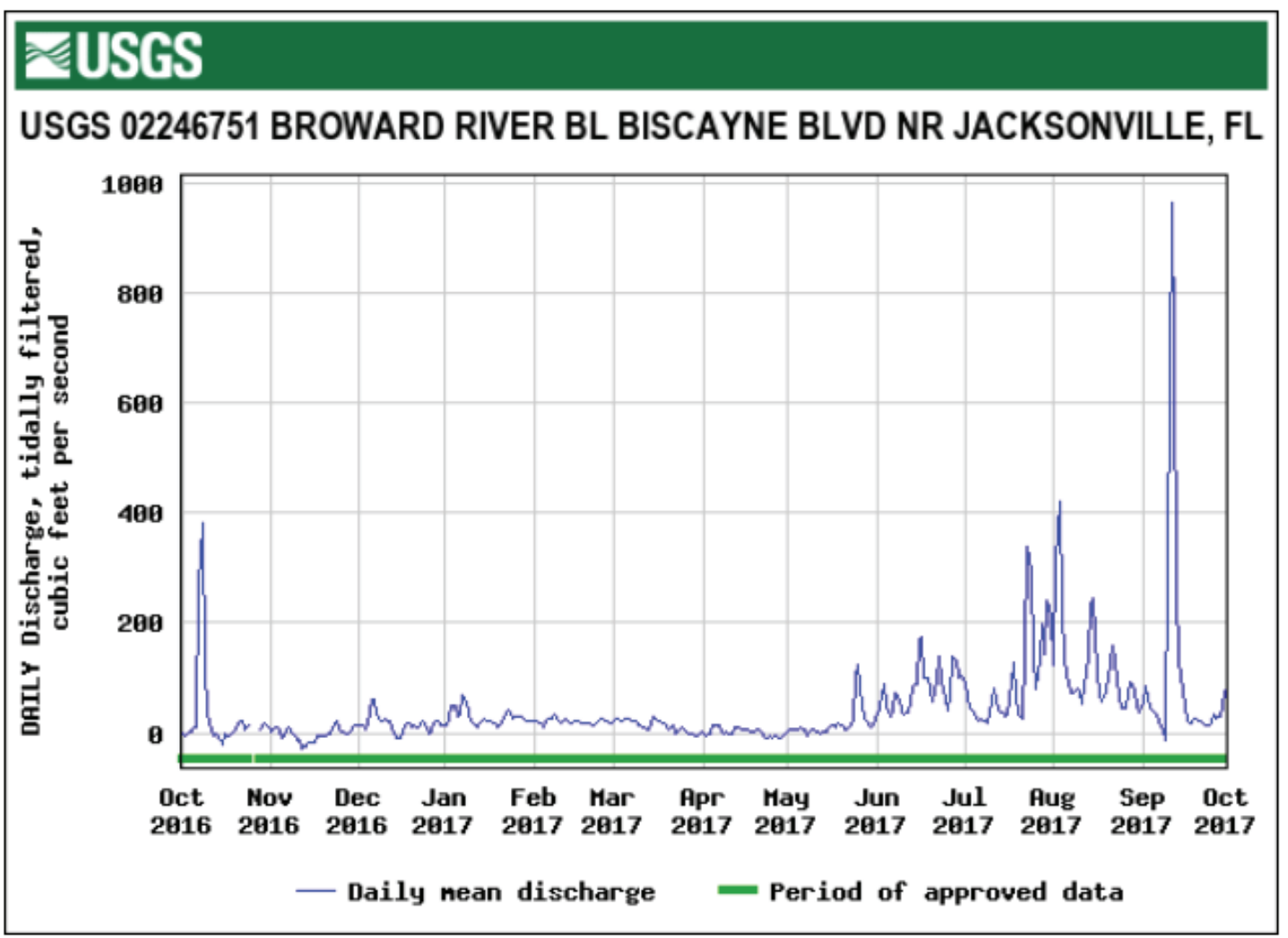

Figure 36. Daily mean tidally filtered discharge for Broward River below Biscayne Boulevard near Jacksonville, Florida.

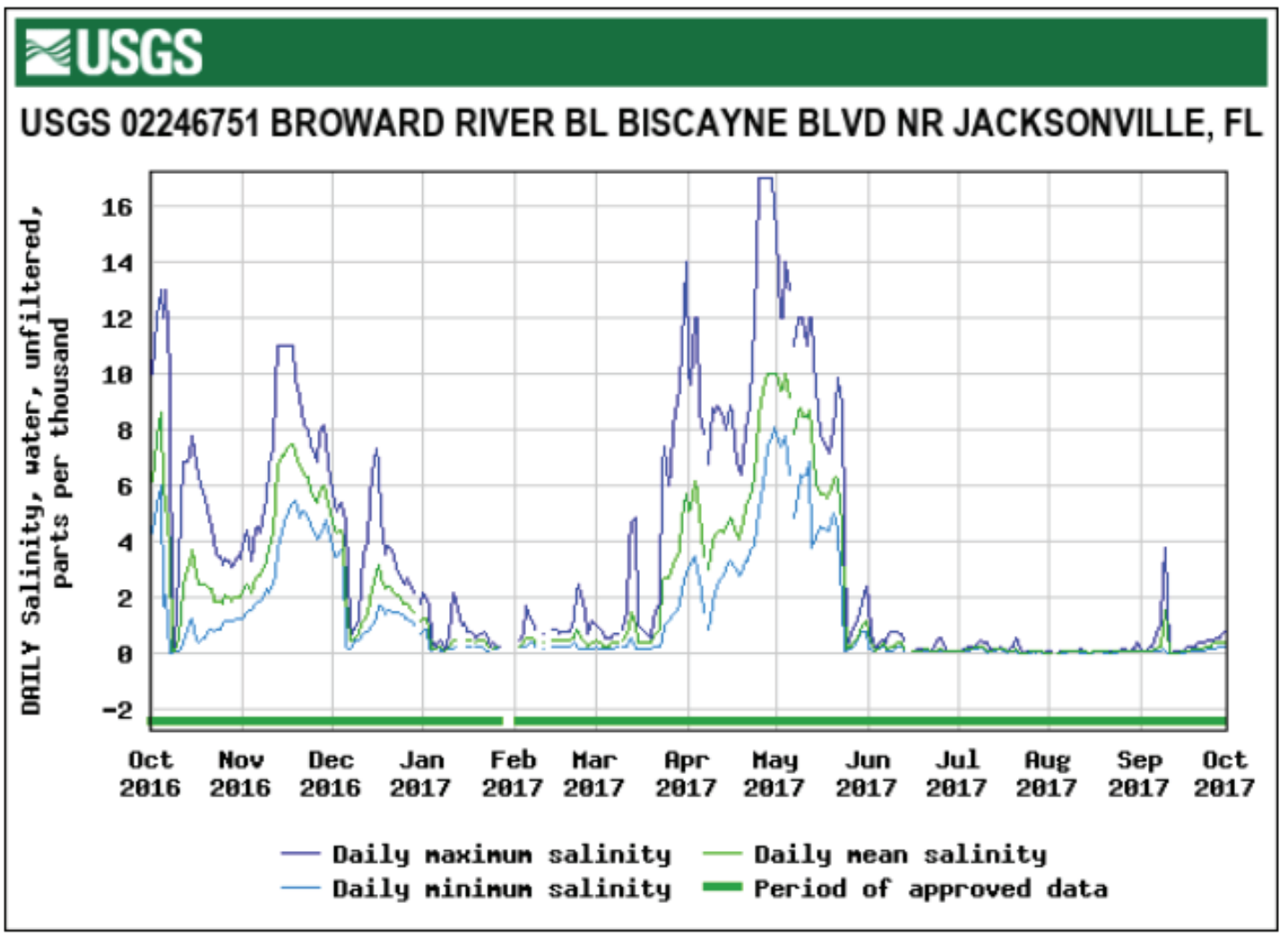

Figure 37. Daily maximum, minimum, and mean salinity for Broward River below Biscayne Boulevard near Jacksonville, Florida. 
Dunn Creek at Dunn Creek Road Near Eastport, FloridaDaily tidally filtered discharge at Dunn Creek ranged from -2.19 to $655 \mathrm{ft}^{3} / \mathrm{s}$ during the 2017 water year, with an annual mean of $29.2 \mathrm{ft}^{3} / \mathrm{s}$ (fig. 38). Discharge was relatively consistent during the period, with three peaks of daily tidally filtered discharge exceeding $200 \mathrm{ft}^{3} / \mathrm{s}$. Discharge data are missing for 11 days in early April because of equipment malfunction. Salinity ranged from 0.0 to $17 \mathrm{ppt}$ during the 2017 water year, with a median of $1.1 \mathrm{ppt}$ and mean of $2.6 \mathrm{ppt}$ (fig. 39).

Clapboard Creek Near Jacksonville, Florida-Daily tidally filtered discharge at Clapboard Creek ranged from -241 to $756 \mathrm{ft}^{3} / \mathrm{s}$ during the 2017 water year, with an annual mean of $56.3 \mathrm{ft}^{3} / \mathrm{s}$ (fig. 40). Tidally filtered discharge remained below $200 \mathrm{ft}^{3} / \mathrm{s}$ during the entire period except part of September because of rainfall from Hurricane Irma (fig. 6).

Clapboard Creek Above Buckhorn Bluff Near Jacksonville, Florida-Salinity at Clapboard Creek ranged from 0.6 to 33 ppt during the 2017 water year, with a median and mean of 21 ppt (fig. 41). Rainfall in the drainage area decreases salinity, as was the case with Hurricane Irma during September 2017 when rainfall in Duval County was 5.6 in. above average and salinity was at a minimum (fig. 6).

\section{Hurricane Matthew}

Hurricane Matthew influenced hydrologic conditions in the study area during October 7-8, 2016. Strong northeast winds pushed water from the Atlantic Ocean into the St. Johns River, while heavy rains increased stage and discharge and lowered salinities at all sites. Maximum gage heights and discharges, as well as minimum salinities, were measured at that time in the project area. October 2016 rainfall in Duval County was 4.3 in. above the average October total because of the effects of Hurricane Matthew (SJRWMD, 2018). The St. Johns River at Jacksonville site recorded the second highest instantaneous discharge $\left(211,000 \mathrm{ft}^{3} / \mathrm{s}\right.$ on October 8,2016$)$ and lowest instantaneous discharge $\left(-274,000 \mathrm{ft}^{3} / \mathrm{s}\right.$ on October 7, 2016) of its period of record (fig. 42). This wide range in discharge was mostly caused by storm surge from Hurricane Matthew, as indicated by the increase in salinity on October 6, 2016 (fig. 43). The effects of heavy rainfall were evident at the Cedar River site, where the instantaneous discharge peaked at more than $3,000 \mathrm{ft}^{3} / \mathrm{s}$ (fig. 44) and salinity decreased to $0.0 \mathrm{ppt}$ as the hurricane passed just off the coast (fig. 45).

\section{Hurricane Irma}

Heavy rainfall and onshore winds from the outer bands of Hurricane Irma influenced the study area beginning September 10, 2017. The large storm added rainfall and runoff to the entire St. Johns River watershed, as indicated by rainfall totals for Duval, Putnam, and Volusia Counties that all exceeded their long-term monthly averages by 5 in. or

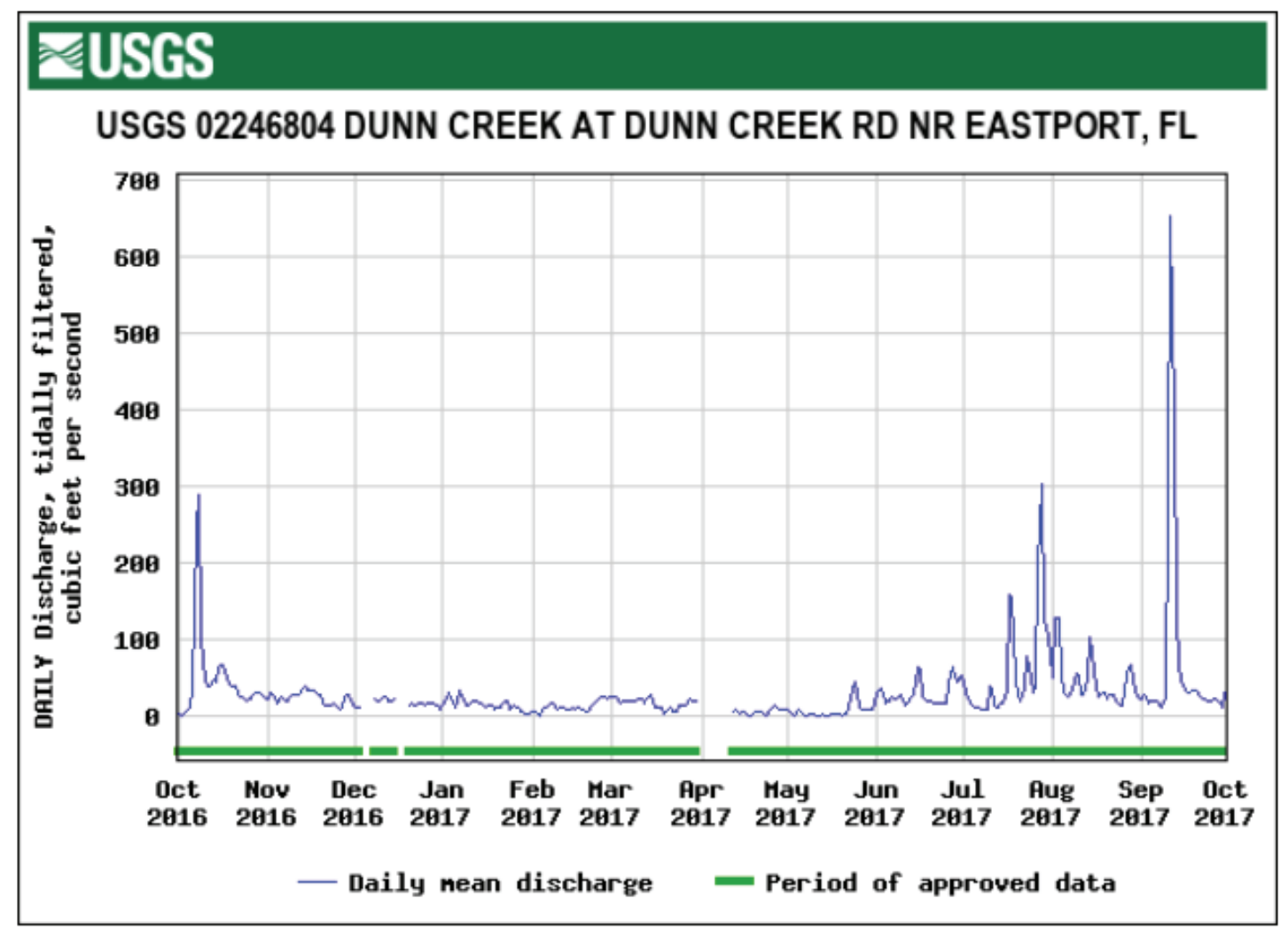

Figure 38. Daily mean tidally filtered discharge for Dunn Creek at Dunn Creek Road near Eastport, Florida. 


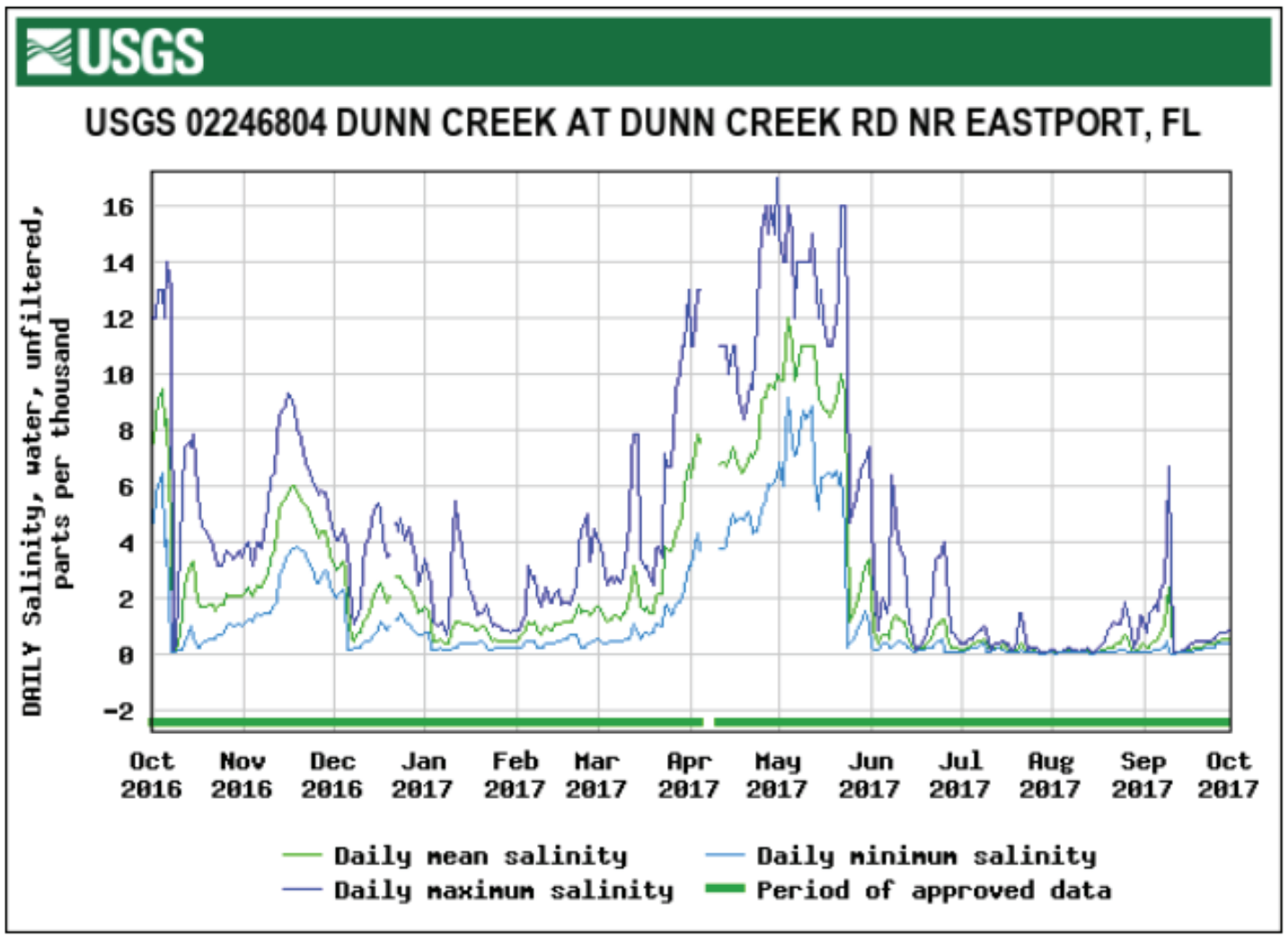

Figure 39. Daily maximum, minimum, and mean salinity for Dunn Creek at Dunn Creek Road near Eastport, Florida.

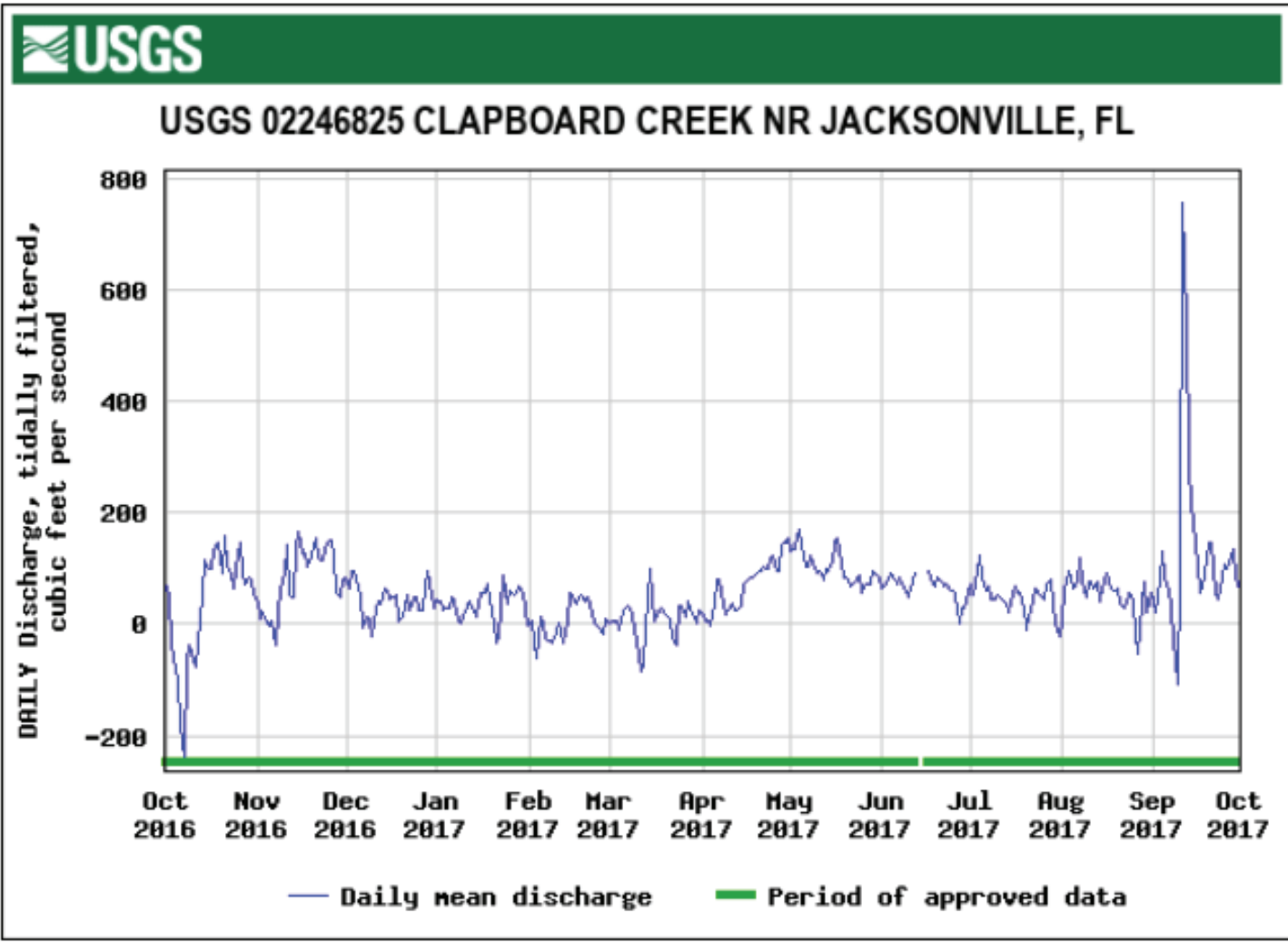

Figure 40. Daily mean tidally filtered discharge for Clapboard Creek near Jacksonville, Florida. 


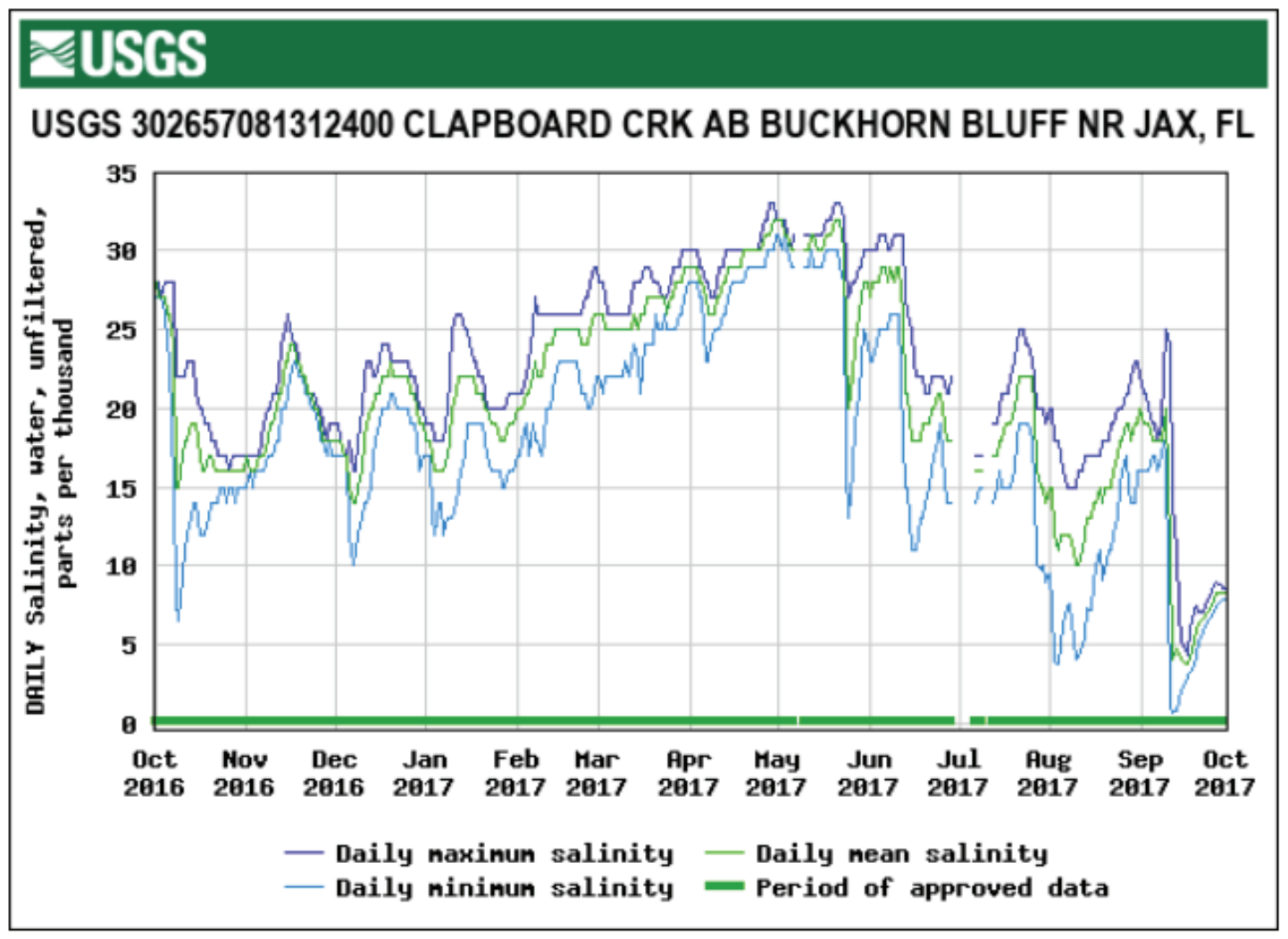

Figure 41. Daily maximum, minimum, and mean salinity for Clapboard Creek above Buckhorn Bluff near Jacksonville, Florida.

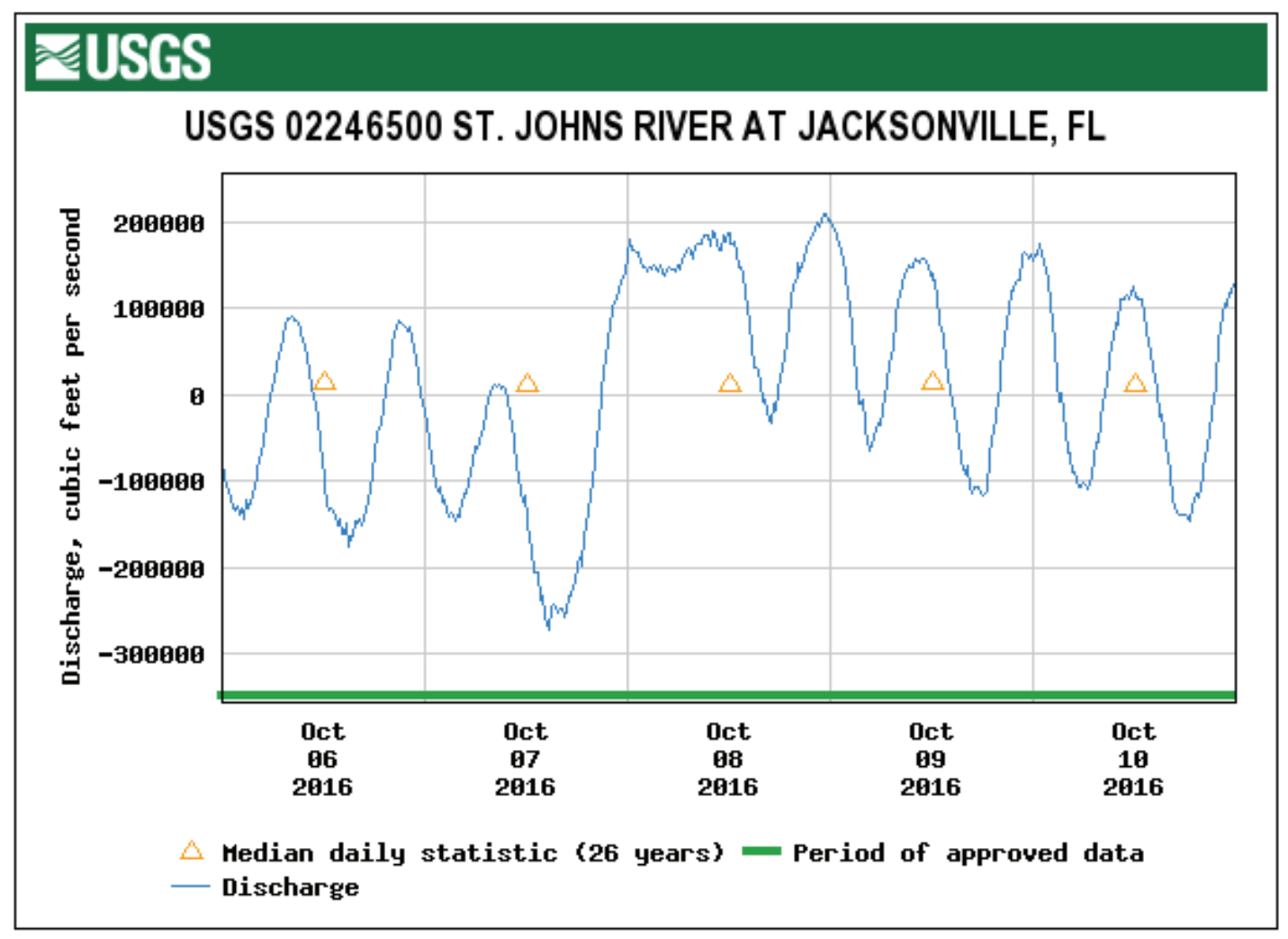

Figure 42. Instantaneous discharge during Hurricane Matthew at St. Johns River at Jacksonville, Florida. 


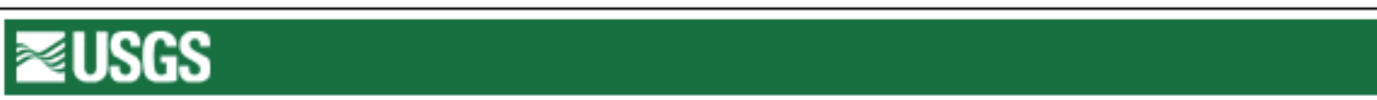

USGS 02246500 ST. JOHNS RIVER AT JACKSONVILLE, FL

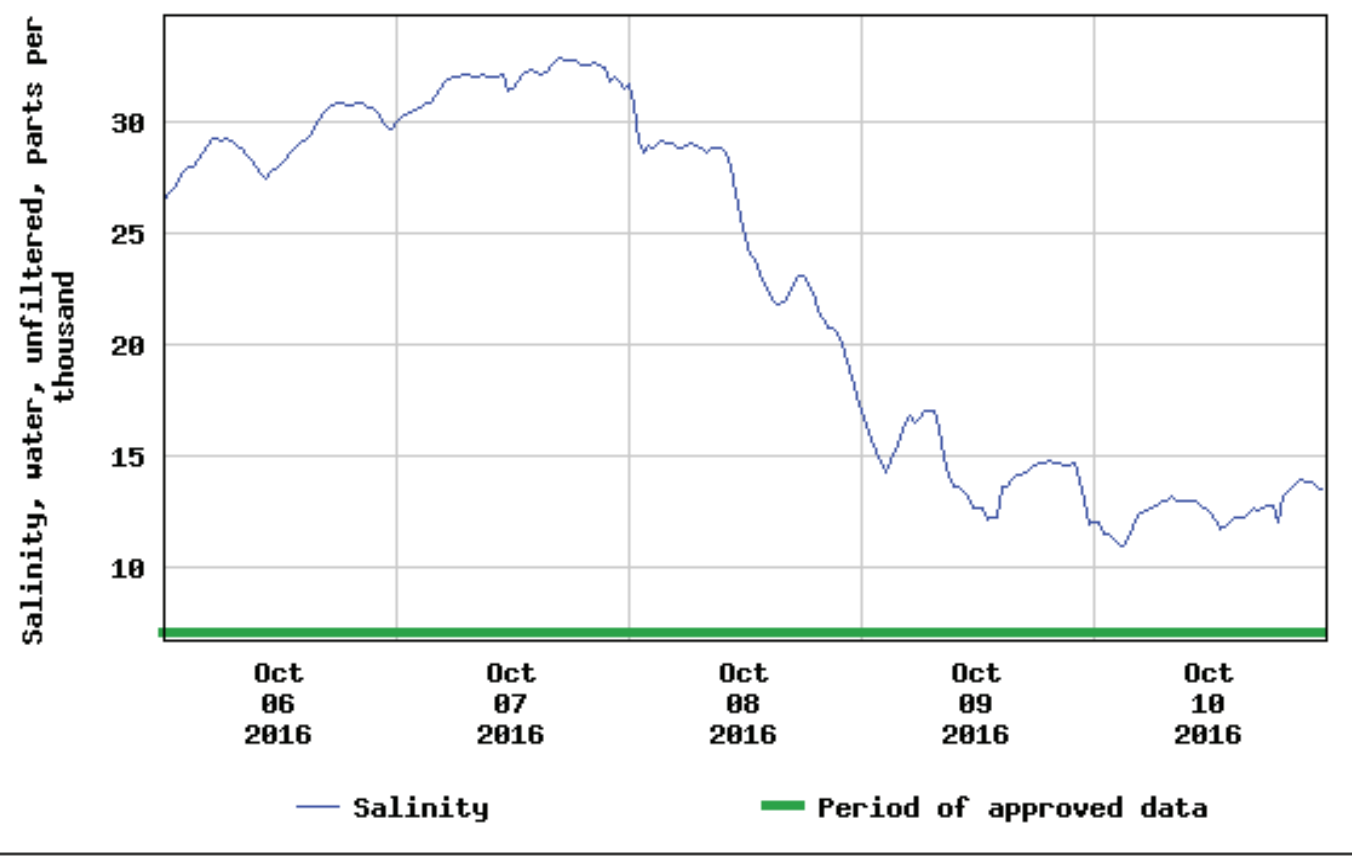

Figure 43. Instantaneous salinity during Hurricane Matthew at St. Johns River at Jacksonville, Florida.

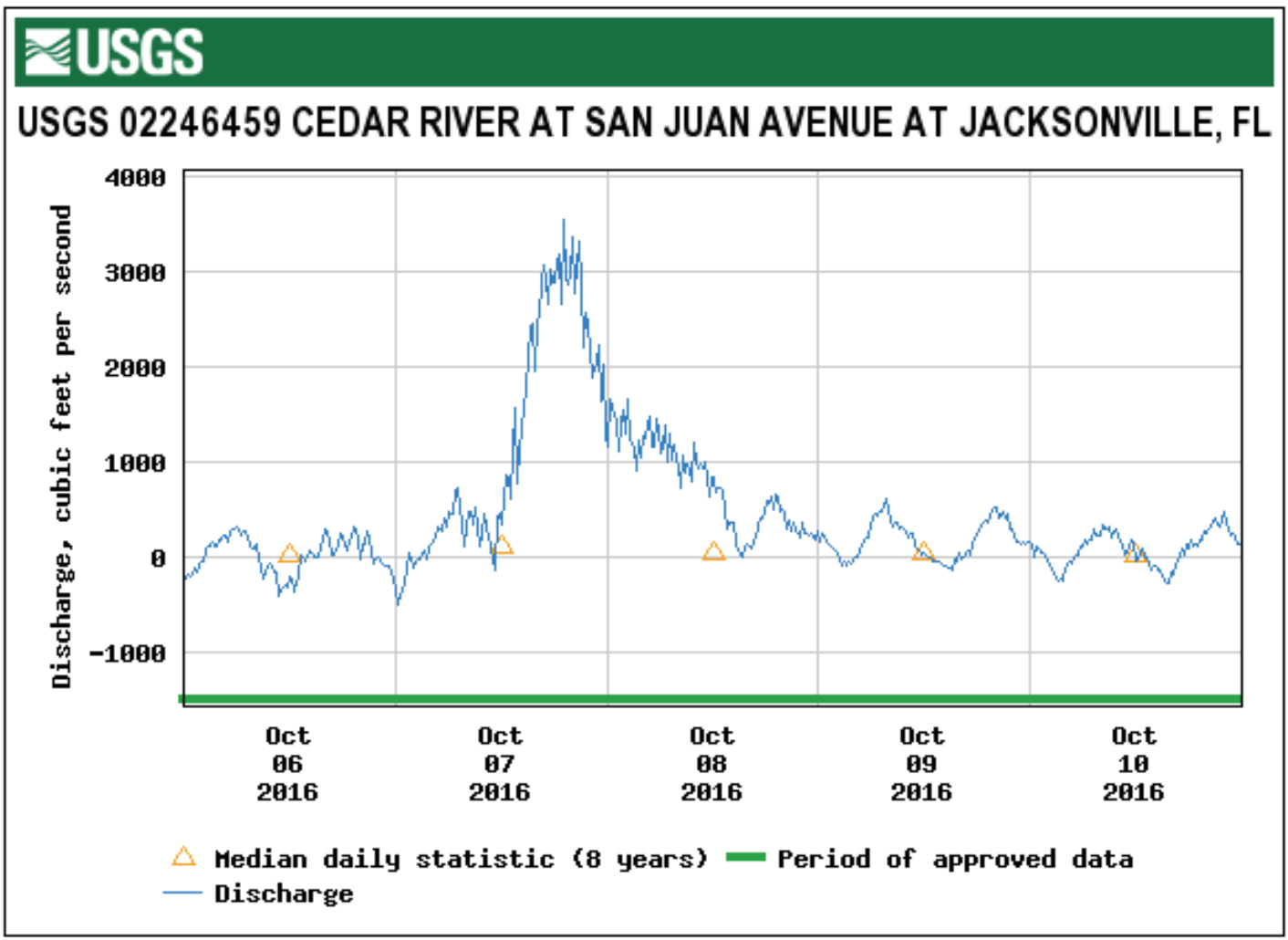

Figure 44. Instantaneous discharge during Hurricane Matthew at Cedar River at San Juan Avenue at Jacksonville, Florida. 


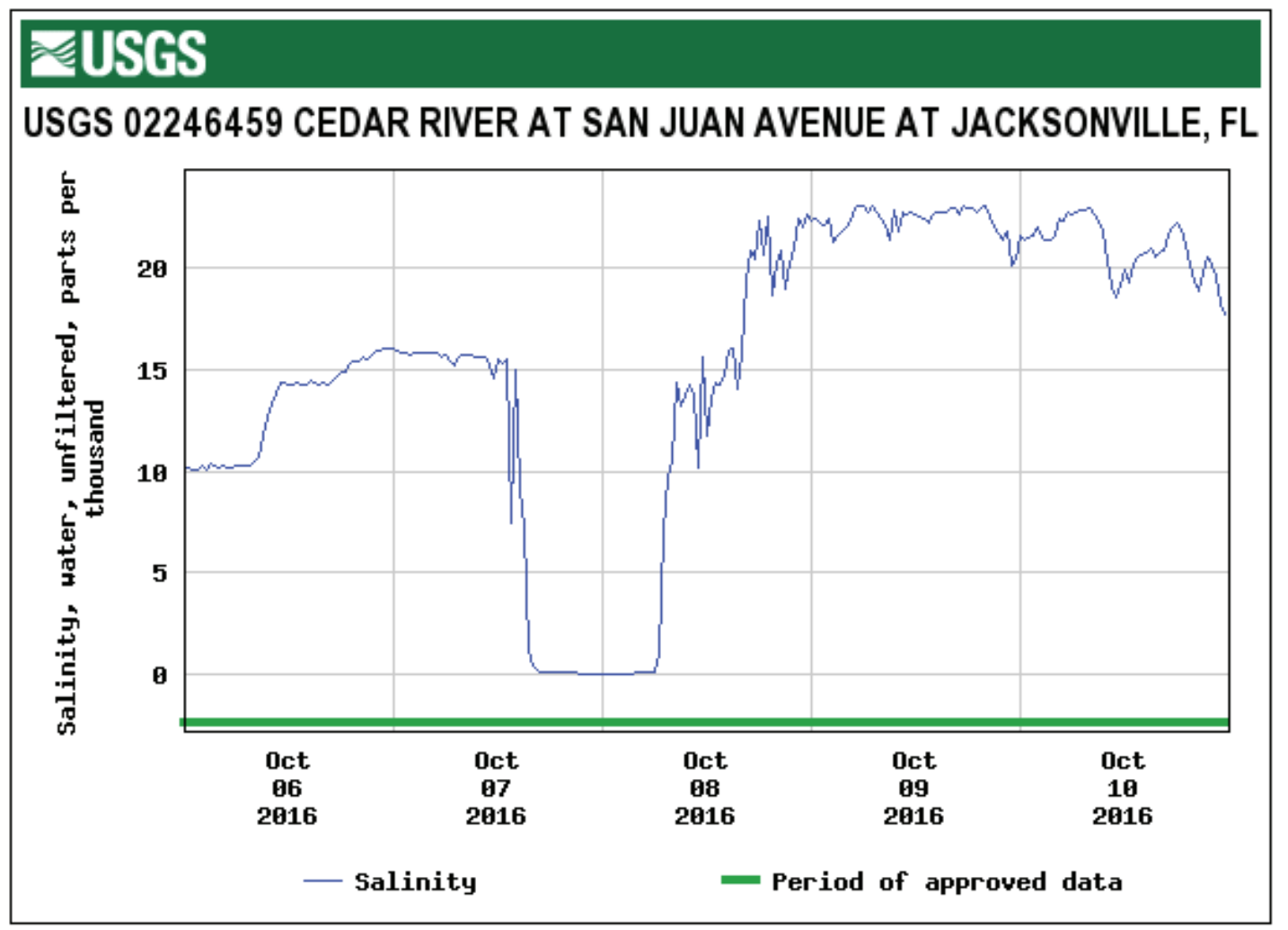

Figure 45. Instantaneous salinity during Hurricane Matthew at Cedar River at San Juan Avenue at Jacksonville, Florida.

more in September (SJRWMD, 2018). Multiple monitoring stations in the project network were damaged by high winds, debris, or flooding, which prevented data from being logged. For their respective periods of record, the St. Johns River at Jacksonville station recorded its highest instantaneous discharge of 232,000 ft $3 / \mathrm{s}$ (fig. 46) and the Ortega River at Kirwin Road near Jacksonville station recorded its second highest instantaneous discharge of $4,650 \mathrm{ft}^{3} / \mathrm{s}$ (fig. 47) on September 11, 2017. The increase of freshwater to the St. Johns River from both rainfall and tributary flow associated with the hurricane is indicated by the decrease in salinity at the St. Johns River at Jacksonville site during the same period (fig. 48). Period-of-record maximum instantaneous discharges were also recorded at the following tributary sites on September 11, 2017 (only 2 years of record): Durbin Creek, Julington Creek, Pottsburg Creek, Trout River, Broward River, Dunn Creek, and Clapboard Creek.

\section{Discharge and Salinity Site Comparison}

Analysis of annual mean tidally filtered discharge for the 2017 water year along the main stem of the St. Johns River indicates that streamflow increased with distance downstream, as expected (fig. 49). Of the tributaries, annual mean tidally filtered discharge was greatest at Trout River; followed by
Durbin Creek, Ortega River, Julington Creek, Pottsburg Creek, and Clapboard Creek discharges, whose annual means were similar; and lastly by Cedar River, Broward River, and Dunn Creek discharges, whose annual means were lowest (fig. 50). Annual mean discharge at all tributary monitoring sites was higher for the 2017 water year than for the 2016 water year (fig. 50). Countywide annual rainfall also increased in Duval, Putnam, and Volusia Counties during these water years (fig. 51). Annual mean salinity for the main-stem sites decreased with distance upstream, which is expected (fig. 52). Clapboard Creek had the highest annual mean salinity of all the tributaries because of its proximity to the Atlantic Ocean. Durbin Creek salinity was the lowest of all monitoring locations and slightly lower than that of Ortega River and Julington Creek (fig. 53). A simple comparison of annual mean salinity among tributary sites and between the 2016 and 2017 water years shows salinity was higher in 2017 at four sites (Julington Creek, Ortega River, Cedar River, and Pottsburg Creek at U.S. 90), lower at four sites (Trout River, Broward River, Dunn Creek, and Clapboard Creek), and remained the same at one site (Durbin Creek) (fig. 53). A comparison of the three main-stem sites with salinity computed for the 2016 water year shows that salinity was higher in 2017 at St. Johns River at Christopher Point and lower in 2017 at St. Johns River at Marco Lake and St. Johns River at Jacksonville (fig. 52). 


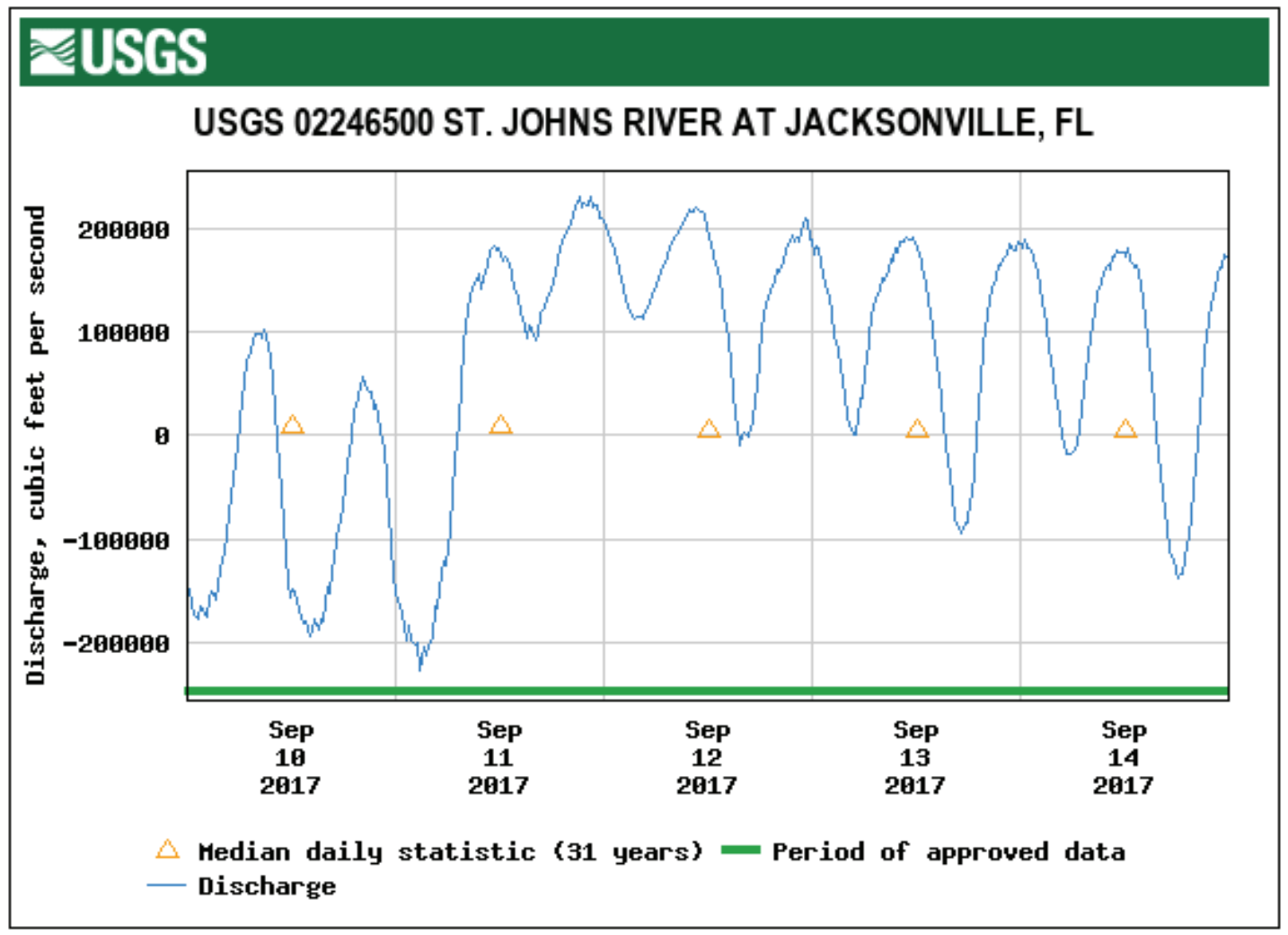

Figure 46. Instantaneous discharge during Hurricane Irma at St. Johns River at Jacksonville, Florida.

\section{ZUSGS}

\section{USGS 02246318 ORTEGA RIVER AT KIRWIN ROAD NEAR JACKSONVILLE,FL}

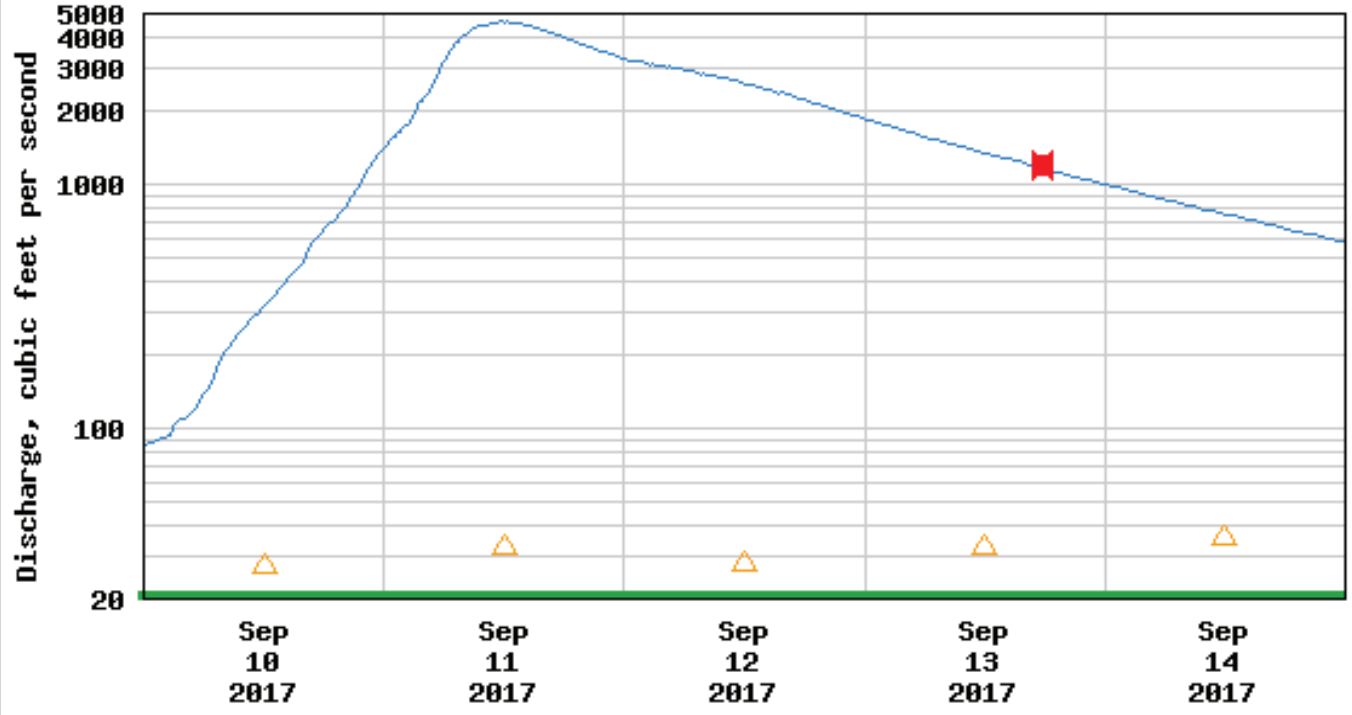

Median daily statistic (12 years) Period of approved data

- Discharge

A Measured discharge

Figure 47. Instantaneous discharge during Hurricane Irma at Ortega River at Kirwin Road near Jacksonville, Florida. 


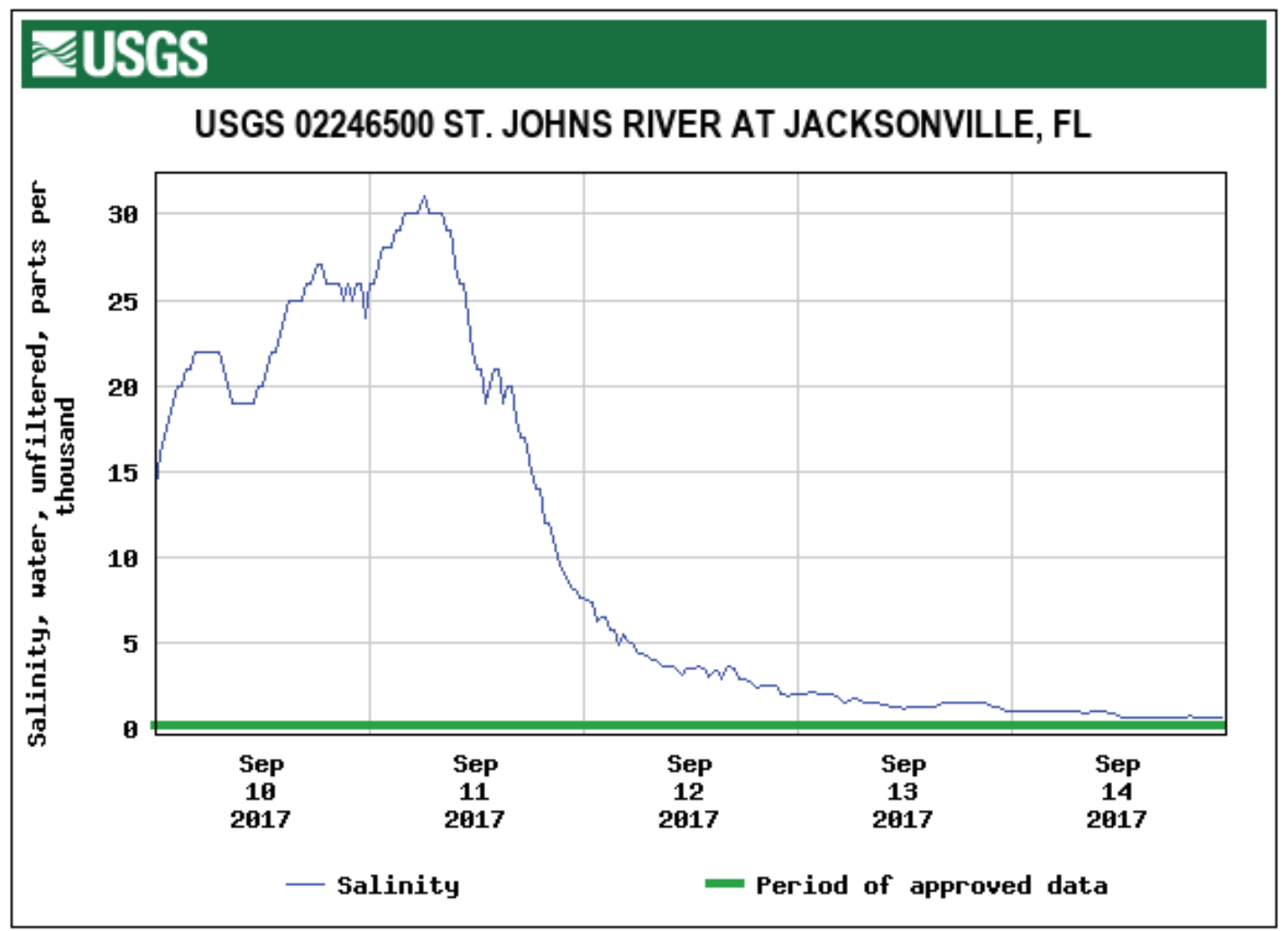

Figure 48. Instantaneous salinity during Hurricane Irma at St. Johns River at Jacksonville, Florida.

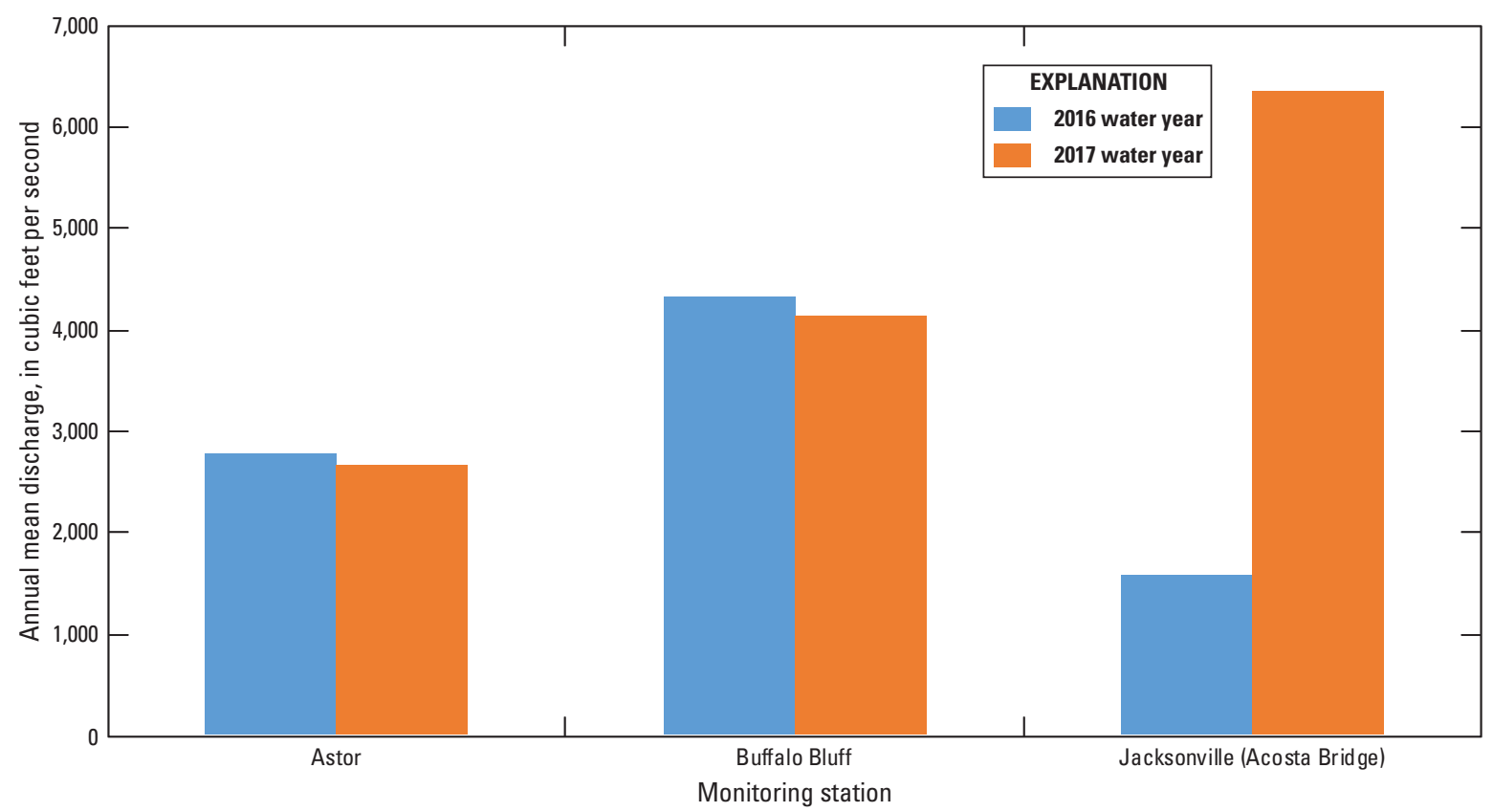

Figure 49. Annual mean discharge at St. Johns River main-stem monitoring sites. 


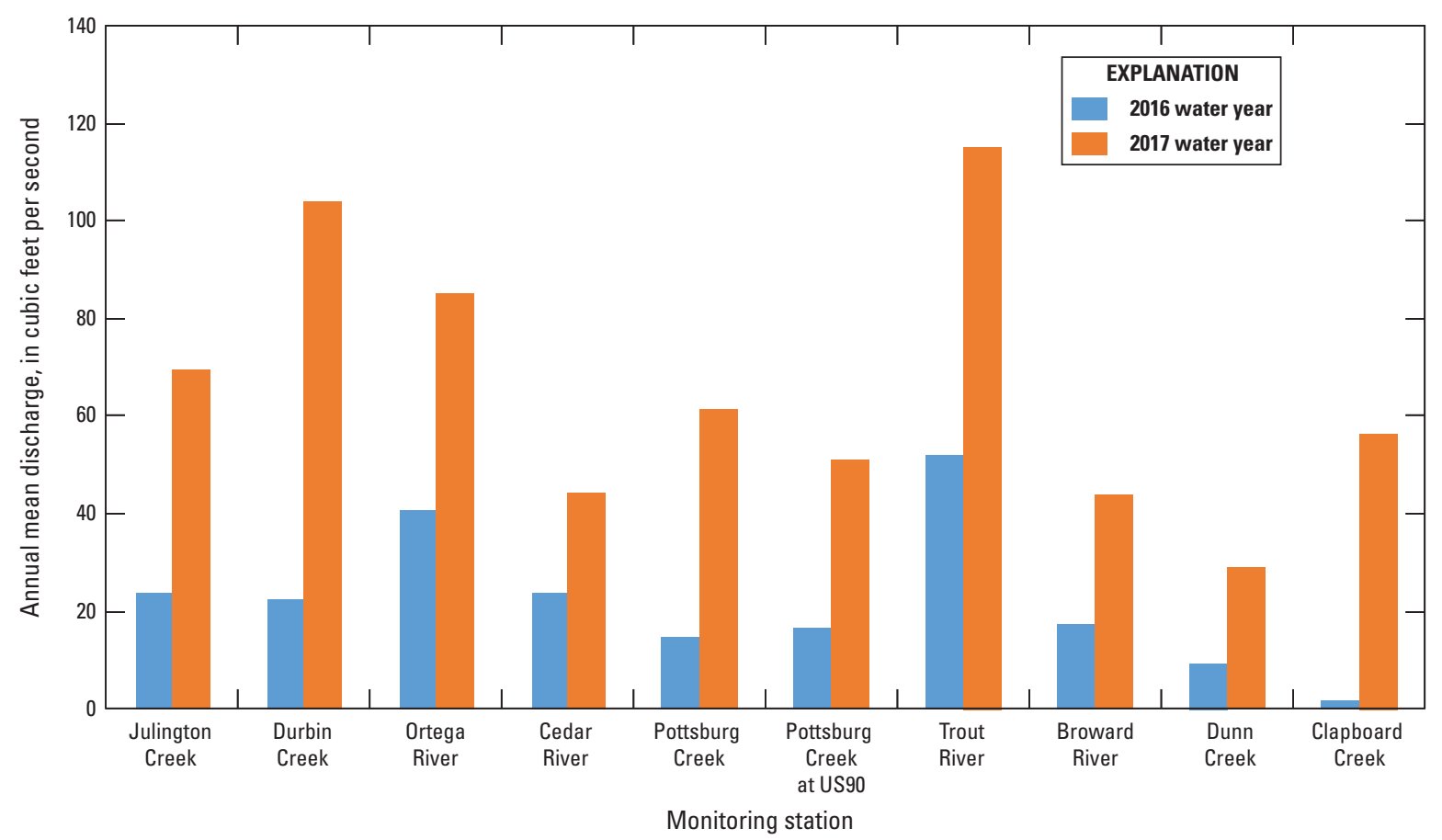

Figure 50. Annual mean discharge at St. Johns River tributary monitoring sites.

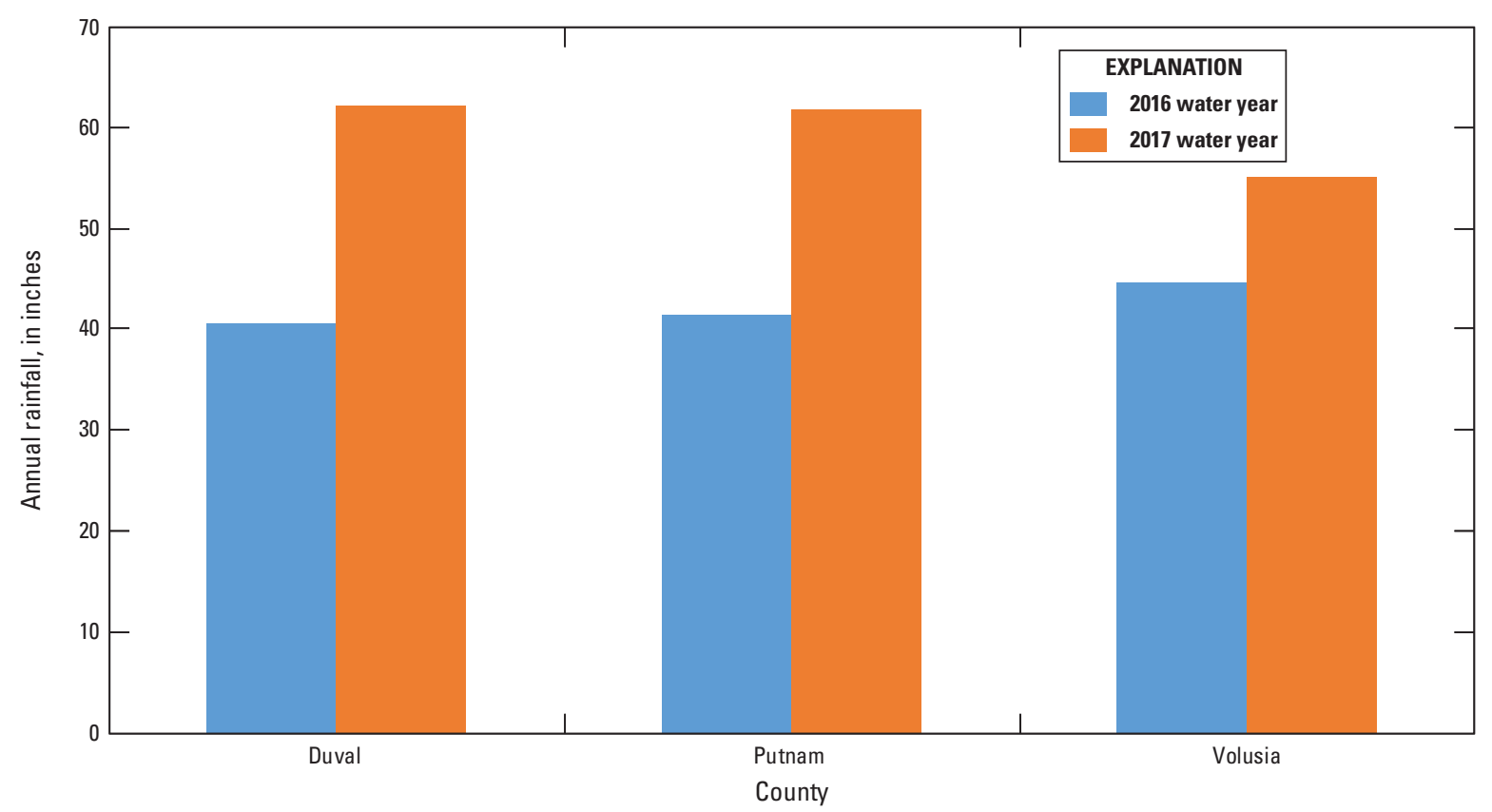

Figure 51. Annual rainfall for Duval, Putnam, and Volusia Counties for 2016 and 2017 water years. 


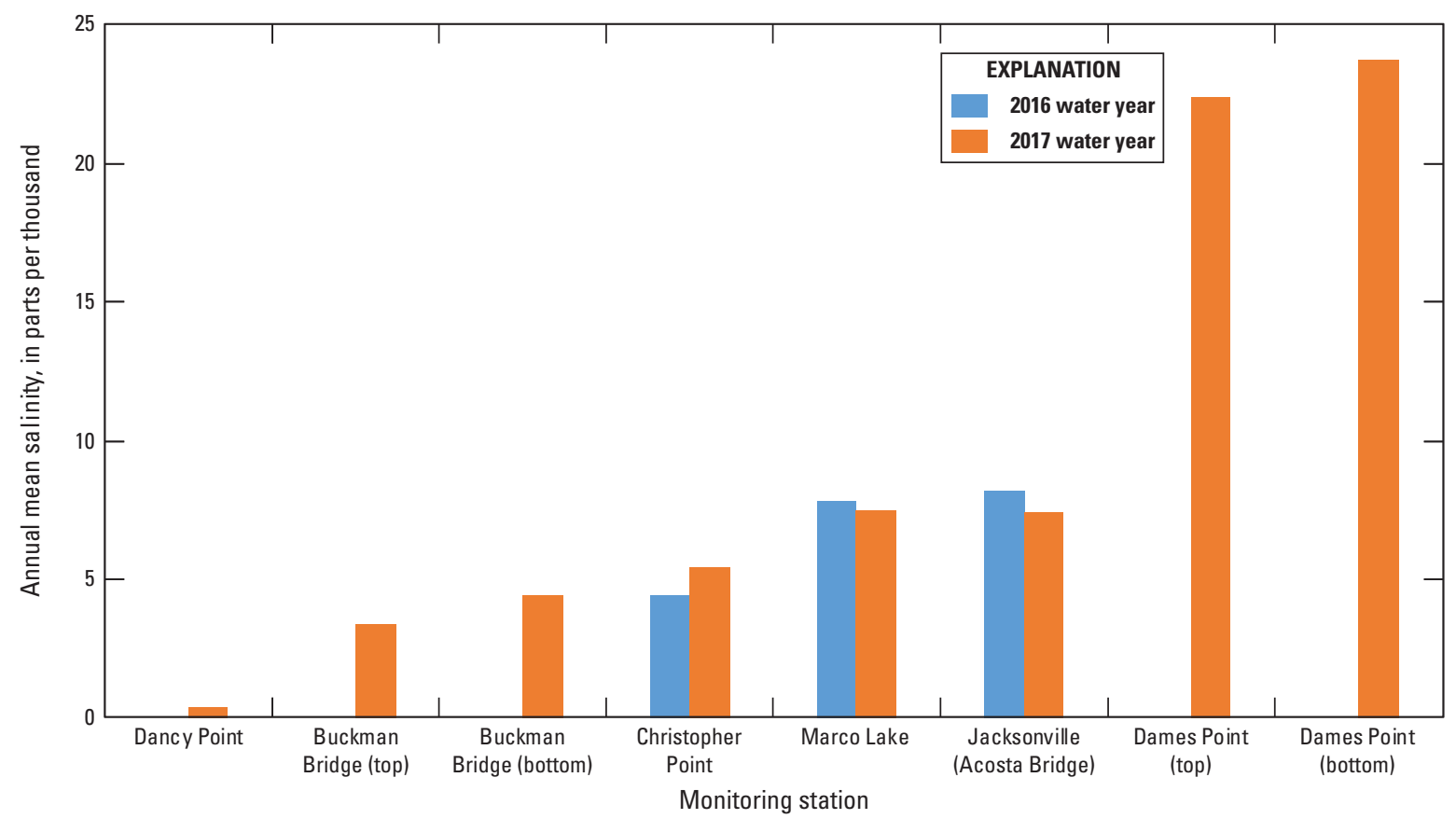

Figure 52. Annual mean salinity at St. Johns River main-stem monitoring sites.

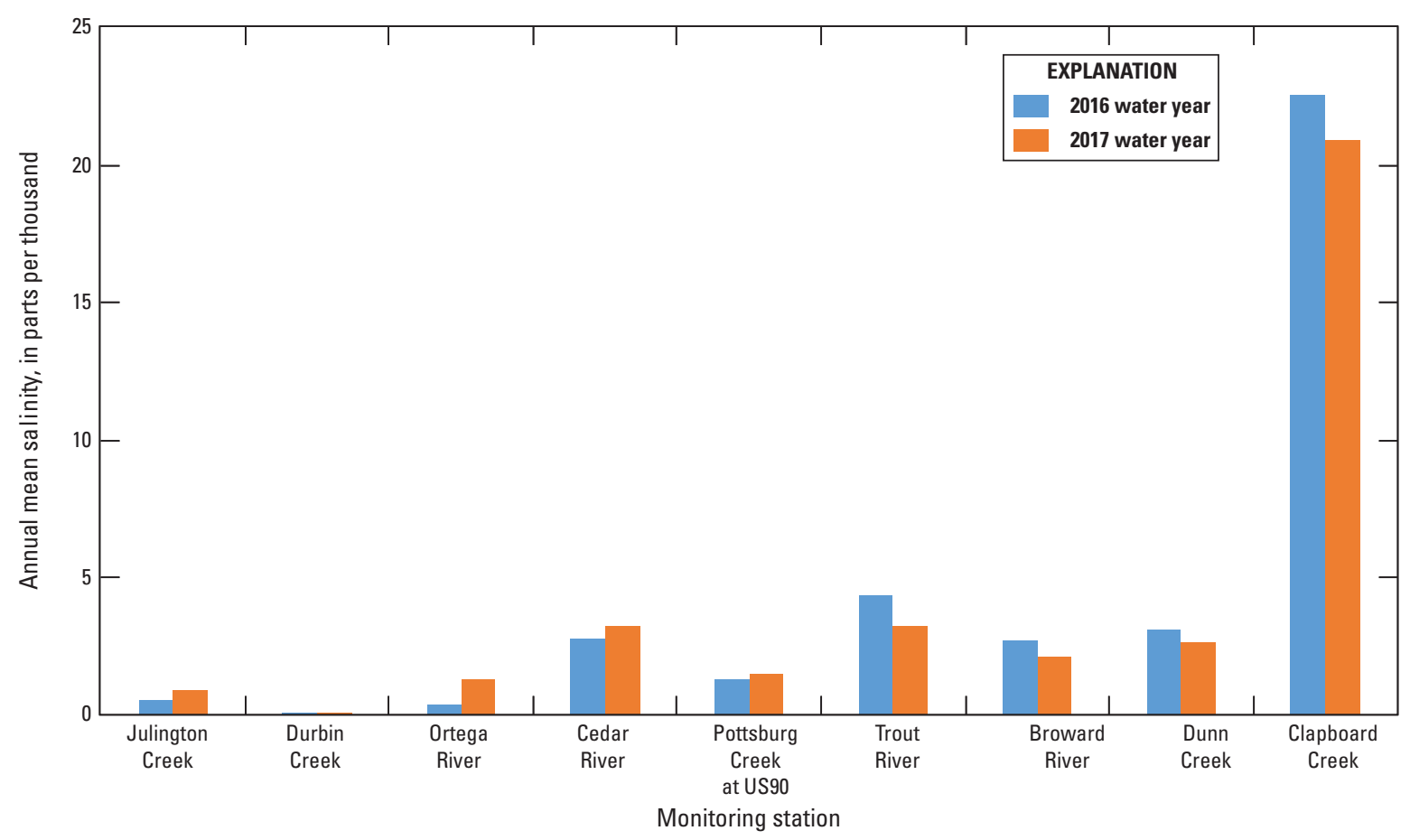

Figure 53. Annual mean salinity at St. Johns River tributary monitoring sites. 


\section{Summary}

The U.S. Geological Survey, in cooperation with the U.S. Army Corps of Engineers, collected baseline data during the 2017 water year, from October 2016 to September 2017, at 23 sites on the St. Johns River and its tributaries. This period of data collection preceded the commencement of dredging by the U.S. Army Corps of Engineers as part of its project to deepen the first 13 river miles of Jacksonville Harbor. Data collection began during the 2016 water year, and this is the second annual report of the study. Stage was measured and discharge was calculated at 13 sites, water temperature and specific conductance were measured at 16 sites, and all parameters were monitored at some sites. Salinity was calculated for each site where water temperature and specific conductance data were collected. Data were collected over a wide range of hydrologic conditions, including a period of below-average rainfall in Duval, St. Johns, Putnam, and Volusia Counties in the winter and spring months, and periods of storm surge and above-average rainfall in the summer months and during Hurricanes Matthew and Irma.

Annual mean discharge at Trout River was greatest among the tributaries, followed by that of Durbin Creek, Ortega River, Julington Creek, Pottsburg Creek, Clapboard Creek, Cedar River, Broward River, and Dunn Creek. The closest tributary site to the Atlantic Ocean, Clapboard Creek, had the highest annual mean salinity of the tributaries, and Durbin Creek had the lowest salinity of all monitoring locations, being slightly lower than that of Ortega River and Julington Creek. Annual mean salinity data for the main-stem sites indicate that salinity decreased with distance upstream from the ocean, which is expected. Annual mean salinity in the tributaries for the 2017 water year was higher than that of the 2016 water year at four monitoring locations, lower at four monitoring locations, and the same at one location. Of the three main-stem sites for which salinity was calculated in the 2016 water year, salinity was higher at one monitoring location in the 2017 water year and lower at two locations. Many factors - such as rainfall, hurricanes, and storm surgeinfluence flow and salinity within the study area.

\section{References Cited}

Florida Department of Environmental Protection [FDEP], 2016, Jacksonville Harbor federal channel expansion permit no. 0129277-017-BI, p. 22-23.
Levesque, V.A., and Oberg, K.A., 2012, Computing discharge using the index velocity method: U.S. Geological Survey Techniques and Methods, book 3, chap. A23, 148 p. [Also available at https://pubs.usgs.gov/tm/3a23/.]

Rantz, S.E., and others, 1982, Measurement and computation of streamflow, v. 1 and 2: U.S. Geological Survey Water-Supply Paper 2175, $631 \mathrm{p}$. [Also available at https://pubs.usgs.gov/wsp/wsp2175/.]

Ryan, P.J., 2018, Continuous stream discharge, salinity, and associated data collected in the lower St. Johns River and its tributaries, Florida, 2016: U.S. Geological Survey Open-File Report 2018-1108, 28 p., accessed December 2018 at https://doi.org/10.3133/ofr20181108.

Sauer, V.B., and Turnipseed, D.P., 2010, Stage measurement at gaging stations: U.S. Geological Survey Techniques and Methods, book 3, chap. A7, 45 p. [Also available at https://pubs.usgs.gov/tm/tm3-a7/.]

Turnipseed, D.P., and Sauer, V.B., 2010, Discharge measurements at gaging stations: U.S. Geological Survey Techniques and Methods, book 3, chap. A8, 87 p. [Also available at https://pubs.usgs.gov/tm/tm3-a8/.]

St. Johns River Water Management District [SJRWMD], 2018, Rainfall summary-Hydrologic conditions report: Accessed October 16, 2018, at http://webapub.sjrwmd.com/agws10/ hydroreport/.

U.S. Army Corps of Engineers [USACE], 2014, Jacksonville Harbor navigation study, Duval County, Florida: U.S. Army Corps of Engineers, Jacksonville District, Final integrated general reevaluation report II and supplemental environmental impact statement. [Also available at http://cdm16021.contentdm.oclc.org/cdm/ref/collection/ p16021 coll7/id/2118.]

U.S. Geological Survey, 2019, USGS water data for the Nation: U.S. Geological Survey National Water Information System database, accessed July 2019, at https://doi.org/10.5066/F7P55KJN.

Wagner, R.J., Boulger, R.W., Jr., Oblinger, C.J., and Smith, B.A., 2006, Guidelines and standard procedures for continuous water-quality monitors - Station operation, record computation, and data reporting: U.S. Geological Survey Techniques and Methods, book 1, chap. D3, 51 p. [Also available at https://pubs.usgs.gov/tm/2006/tm1D3/ pdf/TM1D3.pdf. 

For more information about this publication, contact

Director, Caribbean-Florida Water Science Center

U.S. Geological Survey

4446 Pet Lane, Suite 108

Lutz, FL 33559

(813) 498-5000

For additional information visit

https://www2.usgs.gov/water/caribbeanflorida/index.html

Publishing support provided by

Lafayette Publishing Service Center 


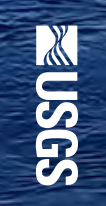

ํㅣㅇ

\&

므

ำ

흔

를

产

离

ำ.

몰

뮴

을

옴

छ'

후

일

$\stackrel{\leftrightarrow}{\digamma}$

을

굼

ฐ

를

के

콤.

흘

\&

음

ISSN 2331-1258 (online)

https://doi.org/10.3133/ofr20191078 